\title{
Congress Steps Out: A Look at Congressional Control of the Executive
}

\author{
H. Lee Watsont
}

In this Comment the author subjects to constitutional analysis an increasingly popular class of statutes whereby Congress seeks to retain jurisdiction over the subject matter of legislation after that legislation is enacted into law. These statutes thus call for Congressmen to step out of their legislative role and exercise the day-to-day discretionary power normally associated with administrative agencies. It is contended that while these statutes may be valid under some circumstances, the provisions often tend to break down the Constitution's checks on governmental power. Furthermore, certain of these statutes place individual members of Congress in a conflict of interest situation where they are allowed to exercise national power without the procedural restraints on assertion of local and personal interests which otherwise underlie the legislative process. The author suggests that both of these effects should be considered contrary to the intent of the Framers, and therefore violative of the Constitution.

\section{Contents}

I. INTRODUCTION

II. Extra-Legislative Roles for Congress: AN HISTORICAL APPROACH

A. The Constitutional Roles of Congress 992

B. The Traditional Roles of Congress 995

1. Early Extra-Legislative Control of the Executive 995

2. Direct Congressional Exercise of Power 1000

C. The Growth of Extra-Legislative Congressional Power 1002

1. The Turn of the Century-Early Developments 1002

2. Early Opposition and Continued Advance 1004

3. The Modern Era 1009

III. CONGRess IN THE Eyes OF the Framers 1029

A. Control of the Legislative Branch of Government 1030

1. Limitation of Individual Powers-

Control of Conflict of Interest

$\dagger$ B.S. 1961, Northwestern University; Ph.D. 1964, University of California, San Diego; J.D. 1975, Boalt Hall School of Law, University of California, Berkeley. 
2. Limitation of the Institutional Power of Congress-Control of Federal Power

B. Four Criteria

IV. The Constitutionality of Non-Legislating CONGRESSIONAL ACTION

A. The Constitutionality of Statutes Delegating Power of Governmental Control to Congressional Committees

1. Formal Committee Power-The Committee Veto 1053

2. Informal Committee Powers

3. The "No Appropriation" Clause and the Committee Veto

B. The Constitutionality of Statutes Authorizing Simple and Concurrent Resolutions

1. Reaction to Administrative ProposalsThe "Laying System"

2. Non-Statutory Control of Executive Actions

3. Congressional Actions Independent of the Executive

\section{INTRODUCTION}

AN ACT

Be it enacted by the Senate and House of Representatives of the United States of America in Congress assembled, that

(a) There is hereby established, as an independent agency within the executive branch, a National Commission on Solar Energy (hereinafter referred to as the "Commission"), which shall be composed of-

(1) two members of the Senate, who shall be members of different political parties and who shall be appointed by the President of the Senate;

(2) two members of the House of Representatives who shall be members of different political parties and who shall be appointed by the Speaker of the House of Representatives; ${ }^{1}$

1. The Education Amendments of 1972, Pub. L. No. 92-318, 86 Stat. 235, 28284, establishes a National Commission on the Financing of Postsecondary Education which is explicitly made a part of the Executive Branch of the government. Its authorized coinposition includes members of Congress. The primary duty of the Commission is to study and report on the impact of various methods of financing postsecondary education. The Commission is authorized to contract out studies to appropriate individ- 
(3) four members of the executive branch of the Government, to be appointed by the President, of whom one shall be from the Department of Commerce; one from the Department of the Interior; and one from the Department of Health, Education, and Welfare;

(4) five members of the general public, to be appointed by the President, of whom at least three shall have scientific training, and at least one shall be a resident of California.

(b)(1) It shall be the duty of the Commission to solicit and review applications from appropriate individuals or institutions for grants-in-aid, not to exceed $\$ 200,000$ each, to pursue research in the field of solar energy.

(2) The Commission is authorized to enter into contracts with such institutions or individuals as it may select to receive such grantsin-aid.

(3) There is hereby authorized to be appropriated $\$ 2,000,000$ to fund such grants-in-aid and, in addition, such sums, not to exceed $\$ 150,000$ as nnay be necessary to enable the Commission to perform its duties under this Act.

(4) No appropriation shall be made under the authority of subsection (b)(3) of this act for any grant-in-aid in excess of $\$ 10,000$ to any individual or institution unless such grant-in-aid shall have been approved by the Committees on Science and Technology of the House and Senate respectively. ${ }^{2}$

(c) Appropriations and funds made available and authority granted pursuant to this Act shall remain available until (a) re-

uals and educational institutions. See also Act of Aug. 1, 1956, ch. 840, 70 Stat. 888. See note 113 infra.

Throughout this Comment statutes which are cited for provisions authorizing "extra-legislative" procedures, see note 14 infra, rather than for their substantive content or effect, will be cited without regard to subsequent history and without giving U.S.C. citations. Footnotes giving collections of provisions of particular types will list these provisions in chronological order to more clearly show their time development, rather than in "whitebook" reverse order.

Several bills before the 93d Congress relating to amnesty for Vietnam draft evaders would create an Amnesty Commission. One nember of this Commission would be appointed by the President, and the remaining four by various members of Congress. This Commission would not merely advise the President, but would affect the status of the individuals involved, and would "thus perform sovereign functions" of the United States. See Hearings before the Subcomm. on Courts, Civil Liberties and the Administration of Justice of the House Committee on the Judiciary, 93d Cong., 2d Sess. 31 (Mar. 8, 11, and 13, 1974) (H.R. 236, H.R. 674, H.R. 2167, H.R. 3100, H.R. 5195, H.R. 10979, H.R. 10980, H.R. 13001, H.R. Con. Res. 144, and H.R. Con. Res. 385) (testimony of Hon. Leon Ulman, Deputy Assistant Attorney General).

2. Provisions of this type, known as "no appropriations" provisions, do not appropriate funds, but establish statutory authority for later appropriation. However, they seemingly forbid by law such appropriation until passed on by the specified committees. Examples of such provisions may be found in the Consumer Product Safety Act, Pub. 
scinded by concurrent resolution of Congress, or (b) April 23, 1976, whichever first occurs. ${ }^{3}$

SEC. 2.(a) The Secretary of the Interior (hereinafter referred to as the "Secretary") is hereby authorized to enter into purchase contracts for the financing, design, construction, and maintenance of solar energy facilities, not to exceed $\$ 500,000,000$.

(b) The Secretary is authorized and directed to acquire by condemnation land necessary for the construction of such facilities. If the condemnation award for any single facility exceeds $\$ 10,000,000$ the Secretary shall notify and submit his recommendations to the Committees on Appropriations of the House of Representatives and the Senate, and if either Committee disapproves the amount of the award within twenty-one days after notice the condemnation proceeding shall be discontinued..$^{4}$

(c) No purchase contract for the construction of such solar energy facilities shall be entered into, pursuant to the authority of this section, until thirty legislative days following submittal to and approval by the Senate and House Committees on Appropriations and the Senate and House Committees for Public Works, of the designs, locations, plans and specifications, including detailed cost estimates, of such facilities. ${ }^{5}$ Once approved, the terms of such contracts shall

L. No. 93-573, 86 Stat. 1207, 1233 (1972), and the Public Buildings Act of 1959, Pub. L. No. $86-249,73$ Stat. 479,480 .

3. A number of statutes have created authority in the Executive, but have made that authority subject to recall by concurrent resolution of the two Houses. The prototype for such legislation was the Lend Lease Act of 1941, ch. 11, 55 Stat. 31. This act provided that:

After June 30,1943, or after the passage of a concurrent resolution of the two houses before June 30,1943 , which declares that the powers conferred by or pursuant to subsection (a) are no longer necessary to promote the defense of the United States, neither the President nor the head of any department or agency shall exercise any of the powers conferred by or pursuant to subsection (a) ....

Id. at 32 .

Continuing appropriations resolutions frequently have provisions of substantially the same effect, providing that funds be available for expenditure for a particular purpose, but that snch availability shall cease upon the passage by both Houses of an appropriation act which does not provide funds for the stated purpose. The termination of funds takes place without regard to presidential approval or disapproval of the appropriation act. See Act of July 1, 1973, Pub. L. No. 93-52, § 101 (a) (4), 87 Stat. 130.

4. A provision similar to that in the text was deleted from the Klamath Land Bill, H.R. 3867, 93d Cong., 1st Sess. (May 8, 1973) (a bill providing for federal acquisition of Klanath Indian tribal land).

5. On a number of occasions Congress has granted statutory authority to the Executive, subject to approval by congressional committee of the proposed exercise of such authority. For example, the Dwight D. Eisenhower Menorial Bicentennial Civic Center Act, Pub. L. No. 92-520, 86 Stat. 1019 (1972) authorized the Commissioner of the District of Columbia to enter into a purchase contract for construction of a new civic center in the Capital, but provided:

No purchase contract for the construction of such civic center shall be entered into, pursuant to the authority of this section, antil thirty legislative days following submittal to and approval by the Senate and House Committees for the 
not be modified except with the consent of the Chairmen of the Senate and House Committees for Public Works. ${ }^{6}$

(d) The Secretary is authorized and directed to make such feasibility studies as may be requested by resolution of the Committee for Public Works of either the Senate or House of Representatives for the placement of solar energy facilities in specified locations, and within a reasonable time shall make a report thereon to the Congress. $^{7}$

SEc. 3. The President is hereby authorized to submit to Congress a plan for the formation of a cabinet level Department of Solar Energy, such plan to take effect upon the expiration of sixty calendar days after the date on which the plan is transmitted to the Congress, but only if during such sixty-day period there has not been passed by the two Houses a concurrent resolution [either House a resolution] stating in substance that the Congress [such House] does not favor the plan. ${ }^{8}$

This hypothetical statute brings together statutory devices which have been used by Congress in attempts to control executve discretion.

District of Columbia, and the Senate and House Committees on Appropriations, of the designs, plans, and specifications, imcluding detailed cost estimates of such civic center.

Id. at 1021 .

Statutes which grant a congressional committee power to approve or disapprove proposed executive action are sometimes called committee veto statutes. Such power may also be given to an entire House of Congress, or to both Houses. See note 8, infra. Generally, these statutes will be referred to as legislative veto statutes.

6. On one occasion a single Congressman has, in effect, been granted a personal power of veto. The Supplemental Appropriation Act of 1953, ch. 758, 66 Stat. 637 required that changes in a pamphlet relating to military housing regulations be approved by the Chairman of the Committee on Appropriations of the House of Representatives. This pamphlet was given the effect of law. Id. at 661 .

7. Congressional committees have been empowered to direct executive expenditures of funds on studies of future public projects specified by the committee. This power may be connected to a committee power to give final approval for public expenditures on such projects. See the Public Buildings Act of 1959, Pub. L. No. 86-249, 73 Stat. 479, 481-84 and the appropriations acts thereunder subsequent to 1962. E.g., Act of Aug. 20, 1964, Pub. L. No. 88-454, 78 Stat. 535, Act of Aug. 30, 1964, Pub. L. No. $88-507,78$ Stat. 640,655 .

8. A series of government reorganization acts, begun in the 1930's, have called for submittal by the President of a plan which would be effective subject to subsequent action by one or both Houses of Congress. See, e.g., Reorganization Act of 1939, ch. 38, 53 Stat. 561, 562-63; Act of June 30, 1932, ch. 3144, § 407, 47 Stat. 414.

Disapproval and termination of executive action by resolution of Congress may be found in a number of contexts. For example, the War Powers Resolution provides in part:

[A]t any time that United States Armed Forces are engaged in hostilities outside the territory of the United States, its possessions and territories without a declaration of war or specific statutory authorization, such forces shall be removed by the President if the Congress so directs by concurrent resolution. Act of Nov. 7, 1973, Pub. L. No. 93-148, \$ 5(c), 87 Stat. 555, 556-57. See also Emergency Petroleun Allocation Act of 1973, Pub. L. No. 93-159, \& 4(g)(2), 87 Stat. 627. 
Their distinguishing feature is that each places upon members of Congress a responsibility to take future action which is not a part of the ordinarily recognized legislative process. Provisions analogous to those illustrated above have been attacked as unconstitutional by numerous Presidents, ${ }^{9}$ with varying degrees of consistency, since 1920 , when President Wilson vetoed two such measures. ${ }^{10}$ Objecting Executives, supported by their respective Attorneys General and frequently by members of Congress itself, ${ }^{11}$ have contended that such statutes either violate the separation of powers principle, or constitute invalid delegations of legislative power which illegally evade the President's veto power. ${ }^{12}$

9. Wilson: 59 CONG. REC. 7026-27, 8609 (1920); Hoover: 76 CONG. REC. 2445 (1933); Roosevelt: H.R. Doc. No. 252, 75th Cong., 1st Sess. (1937); 83 CoNG. Rec. 4487 (1938); 90 CoNg. REc. 6145 (1944); Jackson, A Presidential Legal Opinion, 66 HARv. L. Rev. 1353, 1357-58 (1953) (Publishing a confidential opinion by President Roosevelt); Truman: 97 CoNG. REC. 5374-75 (1951); 98 CoNG. REC. 9756 (1952); Eisenhower: 100 CoNG. REC. 7135 (1954); 101 CoNG. REC. 10459-60 (1955); 102 CoNG. REC. 12959 (1956); PUblic Papers of the Presidents of the Untred States: DWIGHT D. EISENhOWER, 1956, at 648-50 (1956); H.R. Doc. No. 255 Pt. I, 86th Cong., 2d Sess. at M18 (1960); Kennedy: Public Papers of the Presidents of the UNited States: John F. KenNedy, 1963, at 6 (1964); Johnson: Public Papers of the PresiDENTS OF THE UNTTED STATES: LYNDON B. JOHNSON, 1963-64, at 861-62, 1249-51 (1965); 1 WeERLY COMP. PRES. DOCS. 132, 432-33 (1965); 111 CoNG. ReC. 12639-40 (1965); Nixon: 8 Weekiy CoMp. Pres. Docs. 938, 1076 (1972); 9 Weekly Comp. Pres. Docs. 1285-87 (1973); Ford: 10 WeekLY CoMP. Pres. Docs. 1279 (1974). These statutes have also been the subject of several opinions by the Attomey General. 37 Op. ATT'Y GEN. 56 (1933); 41 OP. ATT'Y GEN. 230 (1955); id. at 300 (1957). But see 6 OP. ATT'Y GEN. 680, 683 (1854).

10. See messages of President Wilson, 59 CoNG. REc. 7026-27, 8609 (1920), and 58 CoNo. REC. 8074 (1919) (withdrawal from the League of Nations by concurrent resolution of Congress proposed). While 1919-20 seems to be considered the period of first attempted passage of sucli measures, several earlier statutes might be placed in the same category. E.g., Act of Feb. 14, 1903, ch. 552, § 8, 32 Stat. 829; Act of Mar. 3, 1905 , ch. 1482, \& 2, 33 Stat. 1117, 1147. See discussion accompanying notes 74-78 infra.

11. See, e.g., 76 CoNo. REc. 3539 (1933) (Senator Byrnes); 84 Cong. Rec. 247778 (1939) (Representatives Taber and Wolcott); 84 CoNG. REC. 3090 (1939) (Senator King); 87 CoNG. REC. 1100, 1246, 1269, 1596, 2063-64, 2073-75 (1941) (Senators Clark, Gillette, McCarran, and Murdock); 87 CoNG. REC. 6504-07 (1941) (Senators Adams and Taft); 97 Cong. Rec. 5443 (1951) (Representative Patman); 100 Cong. Rec. 5095 (1954) (Senator Dirksen).

12. Executive condemnation of these measures, while frequent, is not a universal rule. President Kennedy, for example, proposed at one point that Congress give him the power to formulate agricultural programs, retaining for itself the right to nullify the proposed program by simple resolution. See Public Papers of THE PREsidents of THE UnIted STATES: JoHN F. KeNNEDY, 1961, at 192, 196 (1962) (Special Message to the Congress on Agriculture, Marcli 16, 1961). Congress rejected this scheme which would have left it without the power to modify the President's program. See J. Harris, ConGRESSIONAL CONTROL OF ADMINISTRATION 205 (1964) [hereinafter cited as HARRIS].

The use of the committee veto in appropriation acts under the Public Building Act of 1959 , Pub. L. No. 86-249, 73 Stat. 469, originated in the administration. See discussion accompanying note 213 infra. See also the discussion of President Roosevelt's un- 
While several commentators have joined this protest, ${ }^{13}$ academicians and members of the judiciary have generally taken hittle note. The principal work in the legal literature on extra-legislative ${ }^{14}$ control, an article by Robert W. Ginnane, was published in $1953 . .^{15}$ At that time, control by resolution had been used primarily for approval of presidential reorganization plans and for repeal of statutory powers. ${ }^{16}$ The committee veto was then in its formative stage; Congress had attempted to use it on several occasions, but had made little progress in the face of presidential opposition. However, in the twenty-plus years since 1953, and particularly in the 1970's, use of these measures has become relatively widespread. Resolutions have found a wider variety of uses, and committee veto provisions are regularly approved, though often protested.

Despite this development of extra-legislative congressional controls, the paucity of judicial authority on the constitutional validity of these ineasures remains as glaring as it was at the time of Ginnane's work. This may result from the fact that the primcipal effect of these procedures is not identifiable injury to individuals as such, but rather a general shift in the locus of governmental power and the operation of the governmental system. As Ginnane indicated, for example, problems of standing may arise in a challenge of extra-legislative control. ${ }^{17}$ In addition, the political question doctrine may prompt the judiciary to shy away from these questions of distribution of power between the

easy acquiescence to the use of concurrent resolutions, text accompanying notes 154-59 infra.

13. HARRIS 204-48; Ginnane, The Control of Federal Administration by Congressional Resolutions and Committees, 66 HARv. L. REv. 569 (1953) [hereinafter cited as Ginnane]. See also Small, The Committee Veto: Its Current Use and Appraisals of Its Validity, Library of Congress Congressional Research Service Document JK 1015C (Jan. 16, 1967); Rehnquist, Committee Veto: Fifty Years of Sparring Between the Executive and the Legislature, Remarks before the Section of Administrative Law of the American Bar Association, Dallas, Texas (Aug. 12, 1969). But see Cooper \& Cooper, The Legislative Veto and the Constitution, 30 GEo. WASH. L. Rev. 417 (1962) Thereinafter cited as Cooper \& Cooper].

14. In this Comment the term "extra-legislative" is used to connote actions of Congressmen which are not part of, or related to, the process of preparation and passage of a bill for presentation to the President. Statutes authorizing control of governmental powers by extra-legislative action will be referred to as extra-legislative control statutes. The most common forms of these devices-where either a committee or, alternatively, one or both Houses of Congress are einpowered to disapprove administrative actionwill be called committee veto or legislative veto statutes respectively.

15. Ginnane, supra note 13.

16. For a discussion of the historical development of extra-legislative control by Congress, see Section II of this Comment.

17. Ginnane, supra note 13, at 609-11. See also Schlesinger v. Reservists Committee to Stop the War, 418 U.S. 208 (1974) (suit to bar Congressmen from the military reserves-reversed for lack of standing). 
executive and legislative branches. ${ }^{18}$ Thus, this may be an area where any restraint must come from Congress itself.

That the question of the validity of extra-legislative control may be left to Congress does not automatically validate these measures. ${ }^{10}$ On the contrary, it places a heavy burden of responsibility on that body to consider the constitutional implications of using thein. Provisions for extra-legislative control ${ }^{20}$ could significantly change existing governmental power relationships. Availability of the legislative or committee veto, for example, may tempt Congress to create powers in excess of those it would otherwise allow the President. This may result in an increase in federal governmental power which would not have been possible without use of extra-legislative control statutes. Furthermore, by authorizing action by Congress outside the check of the presidential veto power, or action by the individual Houses of Congress without operation of the bicameral check, these devices nay shift the balance of governmental power toward Congress, and allow the legislative branch to dominate the executive, a situation greatly feared by the Framers of the Constitution. ${ }^{21}$ In addition to shifting the locus of governmental power, statutes providing for extra-legislative control may also affect the quality of exercise of that power. A statute which authorizes individual congressmen to make governmental decisions outside the legislative process puts those legislators in a conflict of interest position. Although they are representatives of local interests, they are in a position, without the attenuating effect of congressional balances, to make decisions which affect the national interest. Finally, the creation of power to be exercised by Congress or committee allows power

18. One of the constitutional questions which arises in connection with the validity of extra-legislative control is whether a Congressman, by virtue of the powers delegated by statute, is an officer of the United States, in violation of article $I$, section 6 , clause 2 of the Constitution. The wording of the incompatability portion of this clause, "no Person holding any Office under the United States, shall be a member of either House during his Continuance in Office," coupled with the provision of article I, section 5 , clause 1 that each House shall be the judge of the qualifications of its members, suggests that the relevant decision may indeed be left to Congress by the Constitution.

19. Thus, in deploring use of the committee veto, Senator Everett Dirksen noted: Those provisions were unconstitutional then and they are unconstitutional now. It is true that there has been no pronouncement to that effect by the Supreme Court of the United States or by any other competent Federal court. The reason that it is difficult to test the legality of such statutes is found in the fact that, in order for the matter to be presented to the courts, somebody must have standing to challenge its validity.

However, that fact does not make it constitutional. . . .

100 CONG. REC. 5095 (1954).

20. Compilations of various versions of extra-legislative control and related statutes may be found in notes 78, 113, 115, and 207, infra, and in Appendices A and B.

21. See Section III infra. 
to be wielded by the hand creating it, thereby facilitating actions based on self-interest. ${ }^{22}$

Presidential attacks on these ineasures have been stated largely in conclusory terms, labeling the authorized actions as legislative or executive in nature, and thereby concluding that they are invalid. Defenders of the devices have also been guilty of analysis by label, ${ }^{23}$ concluding, for example, that since the authorized congressional action might be termed an event upon which a statutory power depends, its use is valid. Rather than draw conclusions from labels, it is the purpose of this Comment, in a discussion directed primarily to Congress, to analyze extra-legislative control from the standpoint of its effect on governmental power in the light of the original intent of the Framers. A quote from Justice (then Mr.) Rehnquist suggests the spirit with which we approach this endeavor:

While I subscribe unreservedly to the notion that this particular type of provision is a violation of the constitutional principle of separation of powers, I think it is helpful in analyzing the question to avoid the temptation to generalizations and abstraction.

In my judgment, it is completely futile to try to draw any sharp or logical line between legislative and Executive functions, as if the mere description of the function inexorably caused it to fall under one or the other heading.

Instead of attempting to establish a rigid classification of governInental functions as executive or legislative, it is more fruitful to examine the manner in which the Constitution distributed powers between the President and Congress. ${ }^{24}$

\section{II}

\section{EXTRA-LEgISLATIVE ROLES FOR CONGRESS: AN Historical APPROACH}

The basic function of Congress is to legislate. Normally, Congress lias no further role after it considers and passes on a bill or votes whether to override in the event of a presidential veto. Insofar as Congress engages in activities pursuant to this role, it is acting within what will be referred to in this Comment as the legislative process.

Congress steps outside of the legislative process when it passes and acts according to a statute authorizing later action by resolution or committee vote, thereby retaining jurisdiction over the subject matter

22. Id.

23. See sources cited at note 434 infra.

24. Rehnquist, supra note 13 , at 5, 8. 
of legislation. Such a statute creates a new role for Congress, ambiguously situated between the legislative and executive functions. While not explicitly authorized by the Constitution, neither is this role expressly forbidden. The Constitution specifies that the two Houses of Congress must act jointly in enacting legislation, but it does not define legislation. Likewise, it does not precisely limit certain powers to the executive branch. While the text of the Constitution provides no clear boundaries to congressional activity, however, it does provide several specific checks to Congress' power. These checks may be circumvented when Congress acts outside the legislative process: the bicameral system vesting legislative power jointly in the two Houses of Congress, may be evaded where a statute provides for post-legislative action by a single House or committee. Another check to congressional power, the presidential veto, may also be inoperative when Congress acts outside the legislative process.

This section will catalogue and discuss the accepted constitutional roles of Congress outside the sphere of legislation as a preliminary step to analyzing the validity of extra-legislative controls of administration. It will then trace the development and expansion of Congress' extralegislative statutory powers. First used as tools to facilitate the legislative process, these powers were expanded to give Congress a voice in some major policy decisions regarding execution of the laws, and ultimately came to function as a means by which groups of Congressmen or individual Congressmen may exercise detailed control over the spending of public money, primarily in the area of public building projects. In tracing these developments, the section will also describe the evolution of executive attitudes toward these measures, and detail the scant judicial analysis of their validity. Apart from its purely historical value, this discussion serves two purposes. First, the clironology shows how extralegislative congressional power appears to build upon itself, with early statutes, cases, and Attorney General's opinions used as precedents and justifications for later developments. Second, insofar as early statutes, cases, and opinions are used as precedent for modern extra-legislative activity, the discussion provides an historical context for evaluating their precedential value.

\section{A. The Constitutional Roles of Congress}

The Constitution itself simgles out the individual Houses of Congress for particular, narrowly defined governmental roles beyond the restraints of the legislative process. The House of Representatives alone has power to inrpeach; ${ }^{25}$ only the Senate has the power to convict

25. U.S. CoNST. art. I, $\S 2$, cl. 6. 
following impeachment. ${ }^{26}$ The Senate is empowered to pass upon presidential appointments and to ratify treaties. ${ }^{27}$ In addition, Congress need not seek presidential approval on a vote of adjournment, and the individual Houses may establish their own legislative procedures. ${ }^{28}$

It was established at an early date that presidential approval was unnecessary for a proposed constitutional amendment which had passed both Houses of Congress by the requisite two-thirds majority. ${ }^{29}$ In Hollingsworth $v$. Virginia, ${ }^{30}$ it was argued that the eleventh amendment was void because it had never been presented to the President for approval. Even though two-thirds of each House (the number needed to override a presidential veto) had voted in favor of the amendment, it was contended that should the President veto the measure, the reasons assigued for his disapprobation might dissuade some members of Congress and prevent repassage. ${ }^{31}$ In response, Attorney General Lee pointed out that the first 10 amendments had all been passed without presidential approval. ${ }^{32}$ Mr. Justice Chase dismissed the appellants' contention with the comment: "There can, surely, be no necessity to answer that argument. The negative of the President applies only to the ordinary cases of legislation; He has nothing to do with the proposition, or adoption, of amendments to the Constitution."33 The Court unanimously ruled that the amendinent had properly been adopted..$^{34}$

The Court's language in Hollingsworth might lead one to speculate that only congressional exercise of powers under article I-the article establishing the legislative branch and naning its legislative powersis subject to presidential veto. However, there seems to have been no suggestion by the Framers that congressional exercise of powers granted outside of article $I$ is not subject to presidential veto; ${ }^{35}$ and the

26. Id. art. I, \& 3, cl. 5 .

27. Id. art. II, $\S 2, \mathrm{cl} .2$. In each of the preceding cases the Constitution selects a House of Congress to serve as an instrument to check the powers of other departments of government.

28. Id. art. I, $\$ 7, \mathrm{cl} .2,3$, and $\S 5$, cl. 2.

29. Id. art. V.

30. 3 U.S. ( 3 Dall.) 378 (1798).

31. Id. at 379.

32. Id. at 381 .

33. Id. n.1.

34. Id. at 382 .

35. The Constitution bestows upon Congress a number of powers not found in article I. Congress may set the time for elections, U.S. CoNST. art. II, $\$ 1, \mathrm{cl} .4$; it may direct the places of trial for crimes committed not within any state, id. art. III, $\$ 2$, cl. 3; it may regulate the jurisdiction of federal courts, id. art. III, $\S 2, \mathrm{cl} .2$; it may declare the punishment for treason, id. art. III, $\S 3, \mathrm{cl} .2$; it may effectuate the full faith and credit clause, id. art. IV, $\S 1$; it may admit new states to the union, id. art. IV, $\S 3$, cl. 1; and it may "dispose of and make all needful Rules and Regulations respecting the Territory or other Property belonging to the United States," id. art. IV, \$ 3, cl. 2. For a suggestion that the property clause authorizes extra-legislative procedures, see 97 CoNG. REC. 5437 (1951) (statement of Mr. Vinson). 
possibility seems to have been laid to rest by the Supreme Court in United States v. California. ${ }^{36}$

In that case, involving a suit brought by the Attorney General concerning California's leasing of offshore oil parcels claimed by the federal government, the Court considered the effectiveness of a joint resolution, vetoed by the President, which ceded the land in question to the State. The Court stated:

And no more can we reach such a conclusion because both Houses of Congress passed a joint resolution quitclaiming to the adjacent states a three-mile belt of all land situated under the ocean beyond the low water mark .... . This joint resolution was vetoed by the President. His veto was sustained. Plainly, the resolution does not represent an exercise of the constitutional power of Congress to dispose of public property under Article IV, $\S 3, \mathrm{Cl} .2 .^{37}$

36. 332 U.S. 19 (1946).

37. Id. at 28.

It has been suggested by one pair of authors, discussing the possibility that the legislative veto unconstitutionally deprives the President of his veto power, that the first use of the legislative veto by Congress concerned the making of laws for territories of the United States-arguably an exercise of power under art. IV, § 3, cl. 2. Boner \& Stayton, The Plastic Code in Operation, Co-ordination in Government: A Legislative Responsibility, 39 Tex. L. REv. 20, 22 (1960). The ordinance for the governance of the territory of the United States northwest of the Ohio River of July 13,1787, states:

The governor and judges, or a majority of them, shall adopt aud publish in the district, such laws of the original states, criminal and civil, as may be necessary and best suited to the circumstances of the district, and report them to Congress, from time to time; which laws shall be in force in the district until the organization of the general assembly therein, unless disapproved of by Congress; but afterwards the legislature shall have authority to alter them as they shall think fit.

1 LAWs of THE UNITED States 475, 476 (July 13, 1787). This ordinance was passed not under the Constitution, but under the Articles of Confederation prior to the adoption of the Constitution. On August 7, 1789, Congress adapted the ordinance to the new government, reciting that im order that the ordinance have full effect, "it is requisite that certain provisions should be made, so as to adapt the same to the present Constitution of the United States." Act of Aug. 7, 1789, ch. VIII, § 1, 1 Stat. 50-51. The 1789 act provided for appointment of territorial officers by the President instead of by Congress as had been originally provided, and for the report of certain information to the President instead of to Congress. While the new act did not alter the language allowing disapproval by Congress of territorial laws, it is difficult to take this adoption of the old language as a conscious approval of congressional power to disapprove laws without opportunity for presidential veto. It should be noted, however, that subsequent provisions for territorial laws have contained very similar language. See, e.g., 48 U.S.C. § 1478 (1970). The Constitutional Convention of 1787 considered an analogous situation. The Virginia Plan (presented to the Convention only two months before enactment of the original Northwest Territory ordinance) contemplated that Congress should have the power to annul laws of the states, but gave the President the power to veto such congressional negation. $1 \mathrm{M}$. FARRAND, ReCords of tHe FEDERAI CONVENTION OF 1787, 21 (1966). The final version of the Constitution gave no such power over state law to Congress, and the reference to presidential veto of annulment was unnecessary.

The authors may have inisinterpreted footnote 17 in Sibbach v. Wilson, 312 U.S. 1, 15 (1941). In Sibbach the Court directly compared the statute authorizing congres- 
Thus, of the powers explicitly granted to the two Houses of Congress, only the power to propose constitutional amendments has been interpreted to be not subject to presidential veto. Significantly, this power is a special case set apart by the Constitution not only by the requirement of a two-thirds majority vote for original passage, but also by the detailed specification of further requirements for final passage.

\section{B. The Traditional Roles of Congress}

As the Constitution's plan establishing and distributing governmental powers unfolded and crystallized into a working government, the dividing lines between the executive and legislative spheres of power were not always apparent. In two important respects Congress began to develop practices and procedures which were outside the normal legislative process. It attempted to expand the techriques available for controlling the actions of the executive branch and also sought to develop means of exercising power itself in situations which were arguably administrative rather than legislative. As will be demonstrated by the following discussion, congressional initiatives did not go unnoticed by the executive, and on several occasions Presidents found it necessary to coinbat what they regarded as legislative encroachments. ${ }^{38}$

\section{Early Extra-Legislative Control of the Executive}

Undoubtedly the most recurring of the controversies between the executive and legislative branches imvolved the extent and mechanisin of congressional control over the power Congress creates in the executive. $^{30}$ The controversy began with the 1789 appointment of Alexander Hamilton as Secretary of the Treasury, and matured in subsequent

sional examination of the newly promulgated Federal Rules of Civil Procedure prior to their effectiveness to the acts allowing congressional annulment of territorial laws, and analogized both to the Reorganization Acts (which do allow legislative vetoes-see discussion accompanying note 143 infra). The authors seem to have been misled into believing that both the organic acts and the authorized examination of the Federal Rules of Civil Procedure were legislative veto statutes. The latter states: ". . . Such nnited rules shall not take effect until they shall have been reported to the Congress by the Attorney General at the beginning of a regular session thereof and until after the close of such session." Act of June 19, 1934, ch. 651, $\$ 2,48$ Stat. 1064. This is not a legislative veto provision and Congress can prevent such rules from taking effect only by force of persuasion, or by legislation. See Act of March 30, 1973, Pub. L. No. 93-12, 87 Stat. 9 (joint resolution signed by President preventing rules promulgated by Supreme Court from becoming effective until enacted by Congress). But see Act of Jan. 2, 1975, Pub. I. No. 93-595, $\$ 2,88$ Stat. 1926 (congressional enactinent of new federal evidence rules, authorizing amendinent by the Supreme Court, subject to rejection by simple resolution of either House).

38. See Warren, Presidential Declarations of Independence, 10 BosT. U.L. REv. 1 (1930).

39. See generally HARRIS, supra note 12 . 
debate over control of executive spending. ${ }^{40}$ Hamilton suggested that funds be appropriated under a few generalized headings. Congress accepted this advice, and Hamilton himself exercised many of the functions currently performed by congressional finance committees. Over the course of its first few sessions, Congress became convinced that it had relinquished too much of its fiscal prerogative, and began to appropriate with greater specificity. President Jefferson, in his first message to Congress, supported this trend:

In our care, too, of the public coutributions intrusted to our direction, it would be prudent to multiply barriers against their dissipation, by appropriating specific sums to every specific purpose susceptible of definition; by disallowing applications of money varying from the appropriation in object, or transcending it in amount; by reducing the undefined field of contingencies and thereby circumscribing discretionary powers over money. . . .41

Thus Congress controlled the powers it created by placing statutory and temporal limitations within the authorizing legislation.

The first manifestation of congressional desire to step out of its legislative role and directly control executive action actually occurred during the first session of Congress. In creating the office of Secretary of the Treasury, Congress provided that:

[I]t shall be the duty of the Secretary of the Treasury . . . to make report and give information to either branch of the legislature, in person or in writing (as lie inay be required), respecting all matters referred to him by the Senate or House of Representatives, or which shall appertain to his office. . . . ${ }^{42}$

Pursuant to this authority the House of Representatives directed the Secretary of the Treasury to conduct and report on several studies, and Secretary Hamilton comphed. ${ }^{43}$ Thus the first Congress seems to have established the practice of binding the executive by statute to provide information on subsequent legislative request.

A later device used to exercise direct control over the executive was the resolution. In $1848,{ }^{44}$ Congress determined that a claim by

40. Id. ch. 3.

41. 8 The Writings of Thomas JefFerson, 1801-1806, at 120-21 (P. Ford ed. 1897).

42. Act of Sept. 2, 1789, ch. XII, § 2, 1 Stat. 65-66 (1789). As recorded in the Annals of Congress part of the quoted passage reads: “. . . in person or in writing, (as he inay be required,) respecting ..."2 ANNals of Congress 2231 (appendix). See note 49 infra.

43. For example, on September 21, 1789, the House resolved "[t]hat the Secretary of the Treasury be directed to prepare a plan for that purpose [public credit] and report the same for the House at its next meeting." 1 ANNALS of CoNGress 2041 (1790).

44. Before this time, Congress had used resolutions to deal with matters involving legislative mechanics, and occasionally to express opinions. See 4 HINDS' PRECEDENTS OF THE HOUSE OF REPRESENTATTVES $\$ 3483$ (1907). 
Churchill Gibbs against the United States fell within the scope of a previously enacted statute, an act of July $5,1832,{ }^{45}$ and directed an executive department to liquidate the claim. Attorney General Reverdy Johnson stated in an opinion that deference should be shown the legislature, and that the resolution was binding on the executive. ${ }^{46}$

Only five years later Congress acted in like fashion on the petition of Isaac Bowinan, the two Houses passing resolutions directing liquidation under the same 1832 act. On this occasion, however, Attorney General Caleb Cushing reversed the ruling of his predecessor. ${ }^{47}$ Cushing determined that the practice of directing executive action by congressional resolution was one which "would afford easy ineans of striking the veto power and the rights of minorities out of the Constitution, and conferring on a bare inajority of the two Houses that legislative omnipotence which it was one of the great objects of the Constitution to guard against and avoid."48 Nevertheless, in the same opinion Cushing may have set the cornership for modern extra-legislative control practices. Referring to the act creating the Treasury Department, he suggested that a congressional order to a department pursuant to earlier legislation night be valid:

Of course, no separate resolution of either House can coerce a Head of Department, unless in soine particular in which a law, duly enacted, has subjected him to the direct action of each; and in such case it is to be intended, that, by approving the law, the President has consented to the exercise of such coerciveness on the part of either House. ${ }^{49}$

45. 4 Stat. 563 (1832).

46. 5 OP. ATT'Y GEN. 82 (1849).

47. 6 OP. ATT'Y GEN. 680 (1854).

48. Id. at 692 .

49. Id. at 683. As his sole support for this proposition the Attorney General quoted the Treasury Department act as rendering it "the duty of the Secretary of the Treasury to 'make report and give information to either branch of the legislature, in person or in writing, as he may be required, respecting all matters referred to him ....." Id. Compare note 42 supra, and accompanying text. The Attorney General's omission of parentheses enclosing "as he may be required," and rearrangement of commas perhaps overemphasizes congressional intent to exercise control over the executive. However, Mr. Cushing's position is supported by the mandatory language in subsequent House resolutions. See note 43 supra. While Secretary Hamilton submitted to the resolutions, he was at the same time in a position of almost coinplete dominance over the appropriation process, and was performing tasks soon to be exercised by Congress. See text following note 40 supra. The efficacy of the congressional intent cannot be said to have received a thorough test in the first Congress.

In any event, the Attorney General's induction from a congressional demand for information needed for its appropriation process-arguably within the legislative mechanics exception even though calling for an executive report-to a general congressional ability to provide for subsequent control of powers granted seems quite out of tone with the rest of his opinion. The quoted paragraph should be read in the context of the opinion and in light of the fact that the Attorney General was reversing a very recent opinion of a predecessor on an identical question. 
Not until the late 1800's did Congress begin to use the procedure suggested in Mr. Cushing's opinion. At first the technique was apparently restricted to directives or requests for surveys and reports on river and harbor improvements. On July 1.3, 1892, in an appropriation act for river and harbor projects, Congress authorized preliminary surveys and reports, but stipulated that no report was to be prepared or subinitted by the Secretary of War other than those authorized by law, and that no supplemental report was to be subimitted unless ordered by "resolution of Congress." 50 Similar river and harbor appropriations provisions were retained into the $1900{ }^{\prime} \mathrm{s} .{ }^{51}$

In the years following passage of the 1892 rivers and harbors appropriations act, there seems to have been soine congressional uncertainty concerning the resolutions authorized in that act. The issue was whether the Constitution required a joint resolution signed by the President, or whether a concurrent resolution would suffice. Despite passage in 1894 and 1895 of several concurrent resolutions under the act, ${ }^{52}$ a joint resolution requesting information concerning the harbor at Manitowoc, Wisconsin was introduced in the Senate on February 19,

50. Act of July 13, 1892, ch. 158, § 8, 27 Stat. 88, 116. The prior appropriation act on the same subject had provided that only reports authorized by law were to be submitted. Act of Sept. 19, 1890, ch. 907, § 118, 26 Stat. 426, 465.

51. E.g., Act of Aug. 18, 1894, ch. 299, $\$ 13,28$ Stat. 371-72; Act of June 3, 1896, ch. 314, § 4, 29 Stat. 234, 235; Act of Mar. 3, 1899, ch. 425, § 2, 30 Stat. 1149; Act of June 13, 1902, ch. 1079, 32 Stat. 331, 372; Act of Mar. 3, 1905, ch. 1482, § 2, 33 Stat. 1147; Act of Mar. 2, 1907, ch. 2509, § 2, 34 Stat. 1111. See 2 Hinds' PrECEDENTS OF THE HOUSE OF REPRESENTATIVES $\$ 1593$ (1907).

In 1900 a provision was added to one such appropriation act requiring that where the Secretary's preliminary study indicated that a particular improvement was inadvisable, he could proceed with further studies only at the direction of Congress. Act of June 6,1900 , ch. $790, \S 2,31$ Stat. 579. In 1902 another provision was added authorizing the Committee of Commerce of the Senate or the Committee on Rivers and Harbors of the House to direct that certain surveys and reports be made. Act of June 13,1902 , ch. 1079, $\S 3,32$ Stat. 331, 372. This appears to be one of the earliest authorizations for a committee directive directly to an administrator. See also Act of Mar. 3,1905 , ch. 1482, $\$ 9,33$ Stat. 1149. In 1895 Congress enacted a statute which, while not providing for legislative control of the executive, nevertheless authorized use of simple and concurrent resolutions of Congress to direct the expenditure of previously appropriated funds for the printing of the Congressional Journals. The relevant part of the statute provided:

Orders for printing extra copies shall be by simple, concurrent, or joint resolution. Either House may print extra copies to the amount of five hundred dollars by simple resolution; if the cost exceeds that sum, the printing shall be ordered by concurrent resolution, except when the resolution is self appropriating, when it shall be by joint resolution.

Act of Jan. 12, 1895, ch. 23, $\S 59,28$ Stat. 610 . This use of the concurrent and simple resolution would seem to fall within the category of legislative mechanics. The same statute was the first to require the printing of concurrent resolutions in the Statutes at Large. Id. $\$ 73,28$ Stat. $612,615$.

52. See note 59 infra. 
1896. ${ }^{53}$ Senator Hill questioned whether a joint resolution was necessary. The Senators who responded, including Senator George F. Hoar of Massachusetts, considered the 1892 act to require a joint resolution. $^{54}$ When the question was raised the following day, Senator Hoar indicated that he changed his mind and agreed that a concurrent resolution was sufficient. ${ }^{55}$ To expedite passage, the Manitowoc resolution was retained as a joint resolution, and the question was submitted to the Senate Judiciary Committee. After considering the matter for almost a year, the Committee, emphasizing past practices in its report, theorized that the constitutional requirenent of submission to the President of every vote for "which the concurrence of the Senate and the House of Representatives may be necessary," applies only to instances where the "necessity" is constitutional-that is, in case of exercise by Congress of its legislative power. A non-legislative resolution need not be presented. The matter was said to depend on "the nature or substance of the resolution and not its form." "56 Drawing its support froin Attorney General Cushing's opinion for the proposition that Congress could authorize by statute subsequent non-legislative resolutions, the report concluded that Congress had the right to so require information from the Departments without the President's consent. The report recommended that the word "resolution" in past appropriation acts be replaced by "concurrent resolution" in the future. ${ }^{57}$ This advice was followed."

For several years following release of the report of the Senate Judiciary Committee, concurrent resolutions were given limited use: they were used either for internal housekeeping inatters, such as ordering the printing of documents or correcting enrolled bills, or for directing the preparation of reports on various river and harbor projects, ${ }^{59}$ a matter which had been clearly labeled non-legislative by the coinmittee report. It was not long, however, before Congress sought to extend use of the resolution to other types of information gathering. In 1903, legislation creating the Department of Commerce and Labor provided that the Secretary of Commerce and Labor should "from time to time make such special investigations and reports as he may be re-

53. 28 CONG. REC. 1911-12 (1896).

54. Id.

55. Id. at 1959-60 (1896).

56. S. Rep. No. 1335, 54th Cong., 2d Sess. 8 (1897). See 4 Hinds' Precedents OF THE HOUSE OF REPRESENTATTVES \$\$ 3483-84 (1907).

57. S. REP. No. 1335, 54th Cong., 2d Sess. 9 (1897).

58. E.g., Act of Mar 3, 1899, ch. 425, § 2, 30 Stat. 1149.

59. E.g., 28 Stat. (Appendix) at 12 (June $1 \&$ 27, 1894), 13 (July 2, 1894), 14 (July 26, 1894), 20 (March 2, 1895); 30 Stat. 1795 (June 10, 1897), 1796 (Feb. 2, 1898), 1797 (Apr. 6, 1898), 1798 (Apr. 14, 1898), 1803 (three resolutions, Dec. 20 \& 21, 1898); 31 Stat. 1998 (Jan. 22, 1901), 2007 (March 2, 1901). 
quired to do by the President, or by either House of Congress . . . ." Under the authority of this Act, the House, subsequently resolved:

that the secretary of Commerce and Labor be, and he is hereby, requested to investigate the causes of the low prices of beef cattle in the United States since July 1, 1903, and the unusually large margins between the prices of beef cattle and the selling prices of fresh beef, and whether the said conditions have resulted in whole or in part from any contract, combination in the form of trust or otherwise, or conspiracy in restraint of commerce. ${ }^{61}$

These early uses of resolutions to direct executive action were, notwithstanding the broad scope of Attorney General Cushing's remark, restricted to the gathering of information presumably necessary for legislating, and were not unlike the provision in the 1789 Treasury Department Act. Within slightly over 10 years, however, congrcssional attempts at extra-legislative control were to begin in earnest.

\section{Direct Congressional Exercise of Power}

Almost immediately after Congress came into existence certain practices developed which could be termed exceptions to the rulc that Congress carry out only legislative functions. For example, Congress early assumed power to administer services necessary to the lcgislative function. This power, manifest in different forms, has remained in Congress up to the prescnt day. ${ }^{62}$ Another "historic exception" is the

60. Act of Feb. 14, 1903, ch. 552, § 8, 32 Stat. 825,829 (emphasis added).

61. H.R. Res. 203, 58th Cong., 2d Sess., 38 CoNG. Rec. 2958 (1904). See 2 HINDS' PRECEDENTS OF THE HOUSE OF REPRESENTATIVES $\$ 1594$ (1907).

62. For example, congressional committees have the power to hire and discharge professional and clerical staff. See, e.g., JEFFERSON's MANUAL aNd RULES OF THE HousB OF REPRESENTATIVES, 90th Cong., Rule XI, \& 737 (1967) thereinafter cited as JeFreRsoN's MANUAL]. Congress controls personnel in the Capitol police and the printing of the Congressional Record. 40 U.S.C. $\$ \S 206,206 a$ (1970); 44 U.S.C. ch. 7 (1970). Congress has exhibited a particular interest in control over government printing in general, and the Jomt Committee on Printing is directed to "use any measures it considers necessary to remedy ueglect, delay, duplication, or waste in public printing and binding and the distribution of Government Publications." 44 U.S.C. $\$ 103$ (1970). See discussion accompanying notes $92-96$ infra, and note 51 supra.

Congress also has the power to imprison a person who disrupts its proceedings for the remainder of a legislative session without judicial proceedings. See 6 CaNON's PRECeDENTS OF tHE House of Representatives, $\S \S 332-34$ (1936); 2 Hinds' Precedents OF THE HOUSE OF REPRESENTATIVES $\S \S 1597-1640$ (1907); JEFFERSON'S MANUAL $\S \S 293$. 99. See also In re Chapinan, 166 U.S. 661 (1897); Anderson v. Dunn, 19 U.S. (6 Wheat.) 204 (1821); but see Kilbourn v. Thompson, 103 U.S. 168 (1880). This power was first exercised by the House of Representatives in December, 1795 when two individuals, Randal and Whitney, attempted "to corrupt the integrity of certain meinbers." JEFFERSON'S MANUAL $§ 293$.

Finally, one of the most significant of congressional administrative powers is the exercise of control over the Library of Congress by the Joint Committee of the Library. 
administrative rule performed by members of Congress who serve on the Board of Regents of the Smithsonian Institution. ${ }^{63}$ It is the duty of the regents to administer in trust the bequest of James Smithson, or London, and the members of Congress, of course, share this responsibility. However, the Institution is technically not the property of the United States, ${ }^{64}$ and nuembership on the board arguably does not place one in a position of governmental power.

The placement of Congressmen on commissions, often working with menbers of the executive branch, is another extra-legislative use of legislators with some historical support. ${ }^{65}$ Such use, however, has often been questioned in Congress as possibly violative of the imcompatibility clause of the Constitution. ${ }^{66}$ On December 21,1898 , in response to President McKinley's appointment of a number of Congressmen to various commissions, the House instructed its Judiciary Committee to determine whether any of its mennbers had accepted any office

2 U.S.C. $\$ \S 132 a, 132 b$ (1970). The predecessor of the Library of Congress was established by the appropriation of $\$ 5000$ in 1800 . The appropriation provided:

That for the purchase of such books as may be necessary for the use of Congress .... and for fitting up a suitable apartment for containing them ... the sum of five thousand dollars shall be, and hereby is appropriated; and that said purchase shall be made by the Secretary of the Senate and the Clerk of the House of Representatives, pursuant to such directions as shall be given, and such catalogue as shall be furnished by a joint committee of both houses of Congress ....

Act of April 24, 1800, ch. 37, § 5, 2 Stat. 56.

The Library of Congress was more fornially established by an act of January 26, 1802. This act provided for books purchased under the previous act to be placed in a room in the Capitol, and for the President to appoint a librarian. The President of the Senate and the Speaker of the House were authorized to establish, and from time to time amend, regulations and restrictions as to the Library, and to fix the amount of security bond to be posted by the librarian. A joint committee of three members from each House was to have control of expenditure for books. Act of Jan. 26, 1802, ch. 2, § 6, 2 Stat. 129.

Presently, the librarian, appointed by the President with the advice and consent of the Senate, is directed to make necessary rules and regulations for the Library, and the security bond is set by law. 2 U.S.C. $\$ 136(1970)$. But expenditure to increase Library holdings is still in the hands of the joint committee. 2 U.S.C. $\$ 132 \mathrm{a}$ (1970).

63. The act creating the Smithsonian, Act of Aug. 10, 1846, clr. 178, 9 Stat. 102, also directed that the Board of Regents include three members of each House of Congress. 20 U.S.C. $\$ 42$. Also included on the board are the Chief Justice and the Vice President.

64. See 4 Hinds' Precedents of the House of Representatives $\$ 4346$ (1907).

65. The use by one department of the government of an individual from another for some special purpose was recently illustrated by the selection of the late Chief Justice to head the Warren Commission. Sucl selection has precedent dating back to 1794, when President Washington appointed Chief Justice Jay special envoy to Great Britain to negotiate a particular treaty. For a listing of instances prior to 1905 of such governmental crossing over, including use of Congressmen on commissions, see 39 CoNG. REC. 3849-51 (1905), quoted in 1 Hinds' Precedents of the House of Representatives $\S 493$ (1907). See note 1, supra.

66. See notes 293-94 infra and accompanying text. 
under the United States, and if so, whether such acceptance had vacated the seat of any member. The ensuing committee report, ${ }^{07}$ relying heavily on Mechem's treatise on public office and officers, ${ }^{08}$ concluded that "mere power to investigate some particular subject and report thereon, or to negotiate a treaty of peace, or on sonie commercial subject, and report without power to make binding on the government, does not constitute a person an officer." 69 The report determined that members of Congress had not vacated their seats by accepting positions on the commission to investigate and recommend legislation for the Hawaiian Islands. ${ }^{70}$ The criterion used in this decision-that a men1ber of Congress may be on a commission so long as it has authority only to investigate and report-has generally controlled the creation of commissions with congressional membership. ${ }^{71}$

In short, though the Framers and their successors through the 1800 's knew a Congress with fairly limited powers, Congress developed a number of roles which do not appear legislative when exammed in isolation. Thus, Congress executed laws related to the legislative process and directed the executive to obtain and transmit information. Congress also controlled what might be called legislative agenciessuch as the Joint Committee on the Library, admmistering the Library of Congress ${ }^{72}$ - which resenible administrative agencies. In each of these cases, however, the purpose of Congress was the facilitation of legislation rather than its execution. Thus the new duties did not represent an expansion of Congress' traditional role.

\section{The Growth of Extra-Legislative Congressional Power}

\section{The Turn of the Century-Early Developments}

Around the turn of the century, the two types of congressional activity challenged and upheld as valid legislative activities-legislative command of the executive pursuant to earker statutes, and legislative exercise of statutorily created powers-gradually developed into tech-

67. H. Rep. No. 2205, 55th Cong., 3d Sess. (1899).

68. F. Mechem, Public OfFices and Public Officers (1890). See text accompanying note 392 infra.

69. H. REP. No. 2205, 55th Cong., 3d Sess., part I at 49, quoted in 1 Hinds' PrEcEDENTS OF THE HOUSE OF REPRESENTATIVES $§ 493$ (1907).

70. Id.

71. See, e.g., Hearings on H.R. 236, H.R. 674, H.R. 2167, H.R. 3100, H.R. 5195, H.R. 10979, H.R. 10990, H.R. 1300I, H. Con. Res. 144, and H. Con. Res. 385 Relating to Amnesty Before the Subcomm. on Courts, Civil Liberties, and the Administration of Justice of the House Comm. on the Judiciary, 93d Cong., 2d Sess., Ser. 35, at 31-32 (1974) (statement of Mr. Ulinan).

72. See note 62 supra. 
niques for exercising power neither for the procurement of information for legislative purposes, nor otherwise for legislative ends. The first indications of the change involved the vesting of power in congressional committees to deal with limited problems, occasionally including the right to review decisions of administrative agencies. The earliest example, an act of January $12,1895,{ }^{73}$ dealt primarily with printing of congressional documents, but also gave a congressional committee control over some agency printing. The act created the Joint Committee on Printing and gave that committee power to take whatever ineasures it deeined necessary to reinedy delay and neglect in government printing, to administer bids for public printing, and to approve or disapprove contracts for the furnishing of paper for printing. ${ }^{74}$ The committee was given control over the Public Printer, ${ }^{75}$ an officer to be appointed by the President to administer the Government Printing Office. ${ }^{76}$ This officer was to handle both congressional documents and printing for the executive departments. ${ }^{77}$ There were also a series of enactments authorizimg either a commission with congressional members, or a committee of Congress (generally the Joint Library Committee) to select or approve the selection of land for inemorials to various historic figures, or to approve the design of certain public structures. ${ }^{78}$ While these practices merely utilized the procedures developed in earlier legislation and apparently were within the scope of Attorney General Cushing's earlier dictum, ${ }^{79}$ they marked a distinct break with previous legislative practice. They called for substantive congressional decisions not directed toward the enactment of legislation.

73. Ch. 23, 28 Stat. 601.

74. Id. $\S \S 1-6$.

75. E.g., id. $\$ 11$.

76. Id. $\$ 17$.

77. See id. $\$ \$ 61,73$. The act authorized the Commissioner of Patents to contract out printing under limitations prescribed by the Joint Committee. Id. $\S 43-73,28$ Stat. 620.

78. In 1909 the chairmen of the House and Senate Committees on the Library were named by statute as members of a commission to select a site in Washington, D.C., for a memorial to Alexander Hamilton. Act of Mar. 4, 1909, Pub. Res. No. 59, 35 Stat. 1170. Again in 1911 the chairmen of the same committees were placed on a commission authorized to procure a design for and enter a contract for construction of a memorial to the North American Indian. Act of Dec. 8, 1911, ch. 1, 37 Stat. 45, subject only to approval of the design by the recently created Commission of Fine Arts. Act of May 17, 1910, ch. 243, 36 Stat. 371. Later examples include Act of Mar. 4, 1913, ch. 147, \$ 21, 37 Stat. 884-85 (design of the National Archives); Act of Jan. 15, 1915, Pub. Res. No. 63, 38 Stat. 1222 (site and construction of memorial to General George Gordon Meade); Act of Aug. 31, 1916, ch. 423, 39 Stat. 671 (administration of construction of a memorial to John Ericsson); Act of Mar. 3, 1917, ch. 160, $\$ 7$, 39 Stat. 1046 (approve site and design of memorial to those who died in effort to save women and children aboard the sinking steamship Titanic).

79. See text accompanying note 49 supra. 


\section{Early Opposition and Continued Advance}

After World War I, Congress continued to make extra-legislative use of the resolution and the congressional committee. During this period, however, such congressional activity met with greater opposition, due to political differences between President Wilson and the Congress. For purposes of this Comment, opposition was shown in two important ways. First there was more debate on the constitutional issues than had previously taken place as the President's supporters attempted to block passage of the offending statutes. In addition, the President for the first time found it necessary to veto two measures which he considered to confer improper powers upon Congress.

One of the first challenges to the constitutionality of the use of concurrent resolutions during this period occurred during a 1919 debate on United States membership in the League of Nations. Some members of the Senate insisted upon a treaty provision allowing Congress to declare American withdrawal from the organization by concurrent resolution. Senator Walsh attacked this provision, arguing that it went beyond the concurrent resolution provisions sanctioned by the 1897 Serrate report. ${ }^{80}$ In response it was urged that Congress had the power to base termination of membership on any contingency it cared to choose, and enactunent of a concurrent resolution could be taken as such a contingency. ${ }^{81}$ Thus, passage of a resolution would automatically trigger the announcement of the intention to withdraw allowed by the treaty. ${ }^{82}$ In this view, the resolution would just be an event, no more a legislative act than the infornnation requests sanctioned by the earlier report. The argunent which seems to have prevailed, however, was that the measure would do no harm: at worst the President might have required his concurrence. The possibility that congressional action alone might have been effective, however, would not have survived if the tern "joint" were substituted for "concurrent." 83 Thus, the provision for the concurrent resolution was retained in the Senate version of the Treaty, but the issue was mooted when the United States failed to jom the League of Nations.

The use of concurrent resolutions for non-legislative substantive purposes did not die, however. Congress passed the Budget and Accounting Bill of 1920, which would have created the office of Comptroller General. ${ }^{84}$ The Comptroller was to be regarded as an officer

80. 58 CoNG. Rec. 8075 (1919).

81. Id. at 8077 .

82. Id. at 8074 .

83. Id. at 8121,8135 .

84. H.R. 9783, 66th Cong., 2d Sess. (1920). 
of the United States, ${ }^{85}$ but was to be removable by concurrent resolution of Congress after a hearing and the making of specified findings. The measure was vetoed by President Wilson, who objected to this use of the concurrent resolution, stressing that such use constituted an infringement upon a natural incident of his appoimtment power. ${ }^{86}$ Ignoring the debates of the first Congress over creation of the office of Secretary of the Treasury, ${ }^{87}$ Congressinen in the House argued in response that the President could appoint only to congressionally created offices, and that Congress could define and limit such offices as it desired;ss the passage of a resolution of removal was simply an event which terminated the tenure of the Comptroller. However, this modification of the contingency theory expressed in the Senate debates on the League of Nations was not sufficient to prompt the House to override the veto. $^{89}$

Wilson's veto seems to have had some impact on the practice of authorizing concurrent resolutions, for thereafter Congress discontimued their use even for requesting reports on river and harbor improvements-the subject of the 1897 report. The statutory language was transmuted into a provision for a joint resolution. ${ }^{90}$ While the statute books were by no neans cleansed of measures allowing Congress to request an investigation by resolution, ${ }^{91}$ many years passed before the device was to reappear other than as a nechanism to provide information to Congress.

Only three weeks before the President's veto of the Budget and Accounting Bill, he had taken a similar stand against a measure in the

85. 59 CoNG. Rec. 8612 (1920).

86. Id. at 8609 .

87. The power to remove officers of the United States, was debated at great length by the first Congress. See 1 ANNALS of CoNGress 473-608 (1789) and D. MORGaN, CONGRESS AND THE CONSTITUTION 49-57 (1966). It was concluded that this power must lie in the Executive under the Constitution, and therefore was not subject to legislative grant. In order that this be clearly understood, the first Congress, in creating the office of Secretary of Foreign Affairs, deleted the phrase "to be removable by the President," as indicative of a legislative grant of power. 1 AnNals of CoNGress 600-08 (1789). But the Congress retained a reference to the possibility that the Secretary be removed by the President. 1 Stat. 28, 29 (1789).

88. 59 CONG. REC. 8612 (1920).

89. The following year President Harding signed a bill calling for the reinoval of the Comptroller General by joint resolution. Act of June 10, 1921, ch. 18, $\$ 303,42$ Stat. 23-24.

90. Compare Act of June 5, 1920, ch. 252, § 2, 41 Stat. 1010, with Act of Sept. 22, 1922, ch. 427, § 12, 42 Stat. 1043 and Act of Mar. 3, 1925, ch. 467, \& 8, 43 Stat. 1191. See also Act of June 30, 1922, ch. 253, tit. 2, 42 Stat. 760 and Act of Mar. 2, 1923, ch. 178, tit. 2, 42 Stat. 1420.

91. See, e.g., Act of Nov. 9, 1921, ch. 119, § 19, 42 Stat. 216; Act of Mar. 3, 1925, ch. 468, 43 Stat. 1203. 
Legislative, Executive, and Judicial Appropriation Bill, ${ }^{92}$ which would have bestowed substantive control powers on a joint committee. This bill would have established in the Joint Committee on Printing a veto power over certain types of government publications. Seeing the prospect of committee control over communication between the executive branch and the public, President Wilson rejected the bill as an invasion of the executive function. ${ }^{93}$

Yet Wilson was not consistent in his opposition to the vesting of substantive power in congressional committees. Only the year before the President had signed, apparently without misgiving, a bill establishing a limited version of the same power. ${ }^{94}$ That act had required that all publications within the stated category receive legislative authorization of Congress before being printed, but empowered the Joint Committee, at its discretion, to authorize continued printing until the end of the legislative session. Perliaps the difference in presidential attitude can be attributed to the way in which the powers given by the earlier bill had been used. At the time the President vetoed the later bill, which would have made tle Joint Committee, rather than Congress, the autlorizing body, the Committee liad already put a stop to 106 government publications. ${ }^{95}$ However, the provision for committee control of printing seems no more extreme than other powers given the Joint Committee at least as early as $1895 .{ }^{.6}$

Unlike the use of concurrent resolutions, the flow of committee veto provisions seems to have been unabated by the President's veto. However, committee power remained restricted to relatively minor roles. In the years following the veto, both the Joint Committee on the Library and commissions including the cliairmen of the House and Senate Committees on the Library, continued to select or approve sites and designs for meinorials in the Capital; 97 the Joint Committee on

92. H.R. 12610, 66th Cong., 2d Sess. (1920), set forth in pertinent part at 59 Cong. Rec. 7026 (1920) (message from the President).

93. 59 CONG. REC. 7026 (1920).

94. Act of Mar. 1, 1919, ch. 86, \&11, 40 Stat. 1270.

95. 59 CoNG. REC. 4803 (1920) (remarks of Senator Smoot). The 1919 act also repeated an 1895 provision granting the committee power to take whatever measures necessary to promote efficiency in government printing. Act of Jan. 12, 1895, ch. 23, 8 2, 28 Stat. 601.

96. Compare section 10 of the 1919 act, which placed powers in the hands of individual Congressmen. See note 113 supra, and accompanying text. The act, signed by President Wilson, gave control over allocation of space in government buildings in the Capital to the Public Bnildings Commission. Act of Mar. 1, 1919, ch. 86, $\$ 10$, 40 Stat. 1269-70. Four of the Commission's seven members were to be inembers of Congress selected by the President of the Senate and the Speaker of the House of Representatives.

97. E.g., Act of Aug. 15, 1921, ch. 66, 42 Stat. 170; Act of Dec. 16, 1921, ch. 8, 42 Stat. 349; Act of April 25, 1922, ch. 142, 42 Stat. 499-500; Act of Mar. 3, 1923, ch. 234, 42 Stat. 1444; Act of Mar. 12, 1924, ch. 53, 43 Stat. 21; Act of June 7, 1924, ch. 369, $₹$ 14, 43 Stat. 666; Act of June 7, 1924, ch. 370, $\$ 2,43$ Stat. 666; Act of 
Printing continued to be given substantive powers; 98 and certain land acquisitions for diplomatic use abroad were made subject to approval of a commission, a majority of the members of which were Congressmen. ${ }^{00}$ When appropriations were made for rental of office space, the expenditures were made subject to the discretion of the Public Buildings Commission, which could provide space in government buildings imstead of authorizing the expenditures. ${ }^{100}$ The Commission was also given power to approve leasing or improvement of buildings ${ }^{101}$ or acquisition of buildimgs and building sites ${ }^{102}$ in the Capital.

Although these uses of committees and commissions with congressional membership appear to go beyond the "investigate and report" limitation imposed by the 1898 House report and are not designed as steps in the legislative process, the substantive effects of the provisions seem relatively insignificant. The selection of sites for and design of monuments in the Capital are functions not unlike that exercised by the Regents of the Smithsomian Institution, while the roles of the Joimt Committee on Printing and the Public Buildings Commission seem peculiarly intra-governmental in cliaracter. Only marginally did these bodies exercise those "sovereign functions of government"103 cliaracteristic of governmental officers.

In 1922, the extension of non-legislative governmental power to Congressmen-at the imstance of President Harding, rather than of Congress-once again became the subject of serious congressional debate. On February 24 of that year, the Senate submitted to its Committee on the Judiciary a directive to investigate the constitutionality of the presidential appoimtment of Senator Reed Smoot and Congressman Theodore Burton to a Federal Commission created by the Act of February 9, 1922. ${ }^{104}$ The powers of this Commission, which was authorized to "refund or convert, and extend the time of payment of

June 7, 1924, ch. 372, 43 Stat. 667; Act of Jan. 23, 1925, ch. 88, §§ 3-4, 43 Stat. 788. These provisions required no further action of Congress. Once the committee had taken the requisite action, construction could begin.

98. Act of May 11, 1922, ch. 189, $\S 1,42$ Stat. 541 (regulation of printing of government documents for sale); Act of June 7, 1924, ch. 354, $\$ 1,43$ Stat. 658 (conmittee einpowered to authorize wage levels in the Government Printing Office, and to act as a final appellate body when the Public Printer and a trade committee were unable to agree on wage levels).

99. Act of Mar. 2, 1921, ch. 113, 41 Stat. 1214.

100. E.g., Act of June 12, 1922, ch. 218, 42 Stat. 642; Act of May 28, 1924, ch. 204, tits. 1-2, 43 Stat. 214, 216, 218; Act of June 5, 1924, ch. 266, 43 Stat. 433.

101. Act of July 1, 1922, ch. 259, 42 Stat. 809; Act of May 24, 1924, ch. 203, 43 Stat. 203.

102. Act of May 25, 1926, ch. $380, \S 6,44$ Stat. 634 .

103. F. MECHEM, PUBLIC OFFICE AND OfFICERS $\$ 4$ (1890).

104. Ch. $47, \S 1,42$ Stat. 363 . Unlike statutes providing an extra-legislative role for Congressmen, this act did not require the appointment of legislators. 
... obligation[s] of any foreign governnent held by the United States . . ."105 went beyond the normal investigative function. The Committee, after analyzing the purpose of the officer eligibility clause of the Constitution, ${ }^{106}$ concluded that menibers of the Commission were officers within the meaning of the clause. The report stressed the danger of patronage and undue executive influence on legislation, and declared the two individuals to be ineligible for the respective positions. ${ }^{107}$

Nevertheless, on March 8, 1922, the President transmitted to the Senate, pursuant to its request, an opinion on the matter by Attorney General Daugherty. The Attorney General disagreed with the Judiciary Committee, arguing that the Congressmen's duties as commissioners would not be incompatible with their duties as nenibers of Congress, but indeed would be "auxiliary" thereto and would allow inembers to transmit from Congress any "further consideration[s]" necessary to the adjustment of foreign obligations. ${ }^{108}$ Eniphasizing the limited tenure, restricted object, and lack of emoluments of the position, the Attorney General stated that the appointments did not "offend ... the Constitution." 109 The Senate promptly confirmed the appoimtments.

After the Harding appointments, Congress, with occasional reluctance, continued to use congressional committees, or commissions with congressional membership, for extra-legislative purposes. ${ }^{110}$ There

105. Id. This statement of commission authority was also included in the name of the bill.

106. U.S. CoNsT., art. I, $\S 6$, cl. 2. See text preceding note 294 infra.

The Committee deliberately and explicitly ignored judicial definitions of the term "officer" which had been promulgated in a different context. One of the better known definitions can be found in United States v. Hartwell, 73 U.S. (6 Wall.) 385 (1867): "An office is a public station, or employment, conferred by the appointment of government. The term embraces the ideas of tenure, duration, emolument, and duties." Id. at 393. In Hartwell the Court construed the term as employed in a criminal statute regulating the conduct of officers. Contrary to the practice in interpreting criminal statutes, the Committee held that as used in defining congressional power the term should be interpreted broadly. S. REP. No. 563, 67th Cong., 2d Sess. (1922), quoted in 62 CoNG. ReC. 5259-60 (1922).

107. S. Rep. No. 563, 67th Cong., 2d Sess. (1922), set forth in 62 CoNG. ReC. 5257-60 (1922), quoted in 6 CANNON's PRECEDENTS OF THE HOUSE OF REPRESENTATTVES $\S 64$ (1935).

108. 6 Cannon's Precedents of the House of Representattves $\$ 64$ at 74-75 (1935).

109. Id. at 75.

110. In creating the United States Coal Commission only a few months after the Harding appointments, Congress expressly forbade appointment of Congressmen to membership. Act of Sept. 22, 1922, ch. 412, 42 Stat. 1023. Two years thereafter, however, congressional membership was authorized on the National Capitol Parks Commission, which was given authority to acquire land by purchase or condemnation. Act of June 6, 1924, ch. 270, $\$ \S 1-2,43$ Stat. 463. Although this provision allowed Congress- 
was little presidential opposition until 1937, when President Roosevelt ${ }^{111}$ —on the advice of his Attorney General ${ }^{112}$ - vetoed a joint resolution creating a New York World's Fair Commission, thereby returning the congressional committee to its traditional limited use of investigating and reporting. ${ }^{113}$

\section{The Modern Era \\ a. Reorganization and Springer}

Despite the incidence of congressional inembership on commissions the 1920's, Congress apparently did not resume serious attempts at extra-legislative control over administration activities until the early 1930's. The Legislative Appropriation Act of $1932^{114}$ was the first in a series of reorganization acts providing for such control..$^{115}$

men to expend for public purposes money appropriated by themselves and their colleagues, it was not unlike functions served by the Regents of the Smithsonian Institution or the Library Committee. In 1926, however, Congress created the Foreign Service Building Committee, a majority of which was to be taken from the ranks of Congress. Act of May 7, 1926, ch. 250, $\$ 2,44$ Stat. 403. Acquisition of land in foreign countries by the Secretary of State for the foreign service was to be made only with the concurrence of the Commission. Id. $\$ 1$.

111. H.R. Doc. No. 252, 75th Cong., 1st Sess. 1-2 (1937).

112. 39 OP. ATT'Y GEN. 61 (1937). Attorney General Cummings advised the President that the jomt resolution authorizing a Commission composed chiefly of members of Congress to appoint and prescribe the duties of a United States Commissioner General, oversee expenditure of funds appropriated for the Commission, and administer the powers granted by the resolution, invaded the province of the Executive. Id. at 62 . The Attorney General drew heavily on Springer v. Philippine Islands, 277 U.S. 189 (1928), and upon an opinion of forner Attorney General Mitchell, 37 OP. ATT'Y GEN. 56 (1933), condemning a committee veto provision subsequently vetoed by President Hoover. See discussion accompanying notes 121-36 infra.

113. Congressmen continue to be utilized on commissions, primarily for purposes of study and report. Recent acts establishing commissions and providing for congressional membership thereon include the following: Act of July 24, 1970, Pub. L. No. 91-354, § 2(a), 84 Stat. 468; Act of Sept. 22, 1970, Pub. L. No. 91-405, § 104, 84 Stat. 846; Act of Oct. 15, 1970, Pub. L. No. 91-452, § 1202, 84 Stat. 960; Act of Oct. 27, 1970, Pub. L. No. 91-513, § 601, 84 Stat. 1280; Act of Dec. 31, 1970, Pub. L. No. 91605 , § 123, 84 Stat. 1727; Act of Juue 23, 1972, Pub. L. No. 92-318, $\$ 140$ (b)(1), (g)(1), 86 Stat. 282; Act of July 13, 1972, Pub. L. No. 92-352, § 602, 86 Stat. 497; Act of Oct. 13, 1972, Pub. L. No. 92-484, § 4, 86 Stat. 798; Act of Oct. 13, 1972, Pub. L. No. 92-489, § 2, 86 Stat. 807; Act of Oct. 18, 1972, Pub. L. No. 92-500, 86 Stat. 875; Act of Sept. 30, 1974, Pub. L. No. 93-426, § 5, 88 Stat. 1166; Act of Dec. 19, 1974, Pub. L. No. 93-526, \& 202, 88 Stat. 1695; Act of Dec. 27, 1974, Pub. L. No. 93556, § 4, 88 Stat. 1789; Act of Dec. 31, 1974, Pub. L. No. 93-568, 88 Stat. 1855; Act of Jan. 2, 1975, Pub. L. No. 93-580, 88 Stat. 1910.

114. 47 Stat. 382.

115. Statutes calling for disapproval by simple or concurrent resolution of plans for reorganization submitted to Congress include: Legislative Appropriation Act of 1932, ch. 314, § 407, 47 Stat. 414 (simple resolution disapproval);

Reorganization act of 1939 , ch. $36, \S 5,53$ Stat. 562 (concurrent resolution disapproval); 
The Act authorized the President to consolidate executive agencies and functions by Executive Order. The order was to be ineffective for 60 days, during which period either House of Congress was empowered to "pass a resolution disapproving of such Executive Order, or any part thereof," in which case the order was to be "null and void to the extent of such disapproval." ${ }^{116}$ Thus the Act not only allowed disapproval of the President's proposal by a single House, but it purported to allow selective disapproval. ${ }^{117}$ The Act, which had been approved by the President, was brought under constitutional siege by the Attorney General the following year. In advising the President to veto the Urgent Deficiency Bill, ${ }^{118}$ which contained a committee veto, Attorney General Mitchell said of the Legislative Appropriation Act:

It must be assumed that the functions of the President under this act were executive in their nature or they could not have been constitutionally conferred upon him, and so there was set up a method by which one House of Congress might disapprove Executive action. No one would question the power of Congress to provide for delay in the execution of such an administrative order, or its power to withdraw the authority to make the order, provided the withdrawal takes the form of legislation. The attempt to give to either House of Congress, by action which is not legislation, power to disapprove administrative acts, raises a grave question as to the validity of the entire provision in the Act of June 30, 1932, for Executive reorganization of governmental functions. ${ }^{110}$

The primary target of the Attorney General's opinion, however,

Reorganization Act of 1945, ch. 582, § 6,59 Stat. 616 (concurrent resolution disapproval);

Reorganization Act of 1949, ch. 226, § 6, 63 Stat. 205 (simple resolution disapproval);

Defense Reorganization Act of 1958, Pub. L. No. 85-599, §3, 72 Stat. 514-15 (plan submitted by Secretary of Defense, simple resolution disapproval);

Arms Control and Disarmament Act, Pub. L. No. 87-297, § 47, 75 Stat. 638 (1961) (simple resolution disapproval);

Act of Mar. 24, 1972, Pub. L. No. 92-261, § 5, 86 Stat. 107 (simple resolution disapproval).

116. 47 Stat. 414. Under this Act President Hoover submitted several reorganization plans in December 1932. All were disapproved. H.R. Res. 334, 72d Cong., 2d Sess., 76 CoNG. REC. 2126 (1933).

117. This power was never exercised by either House.

118. H.R. 13975 72d Cong., 2d Sess. (1933).

119. 37 OP. ATT'Y GEN. 56, 63-64 (1933). Before the Attorney General issued his opinion on the Urgent Deficiency Bill, Congress had provided for removal by concurrent resolution of members of the T.V.A. board. 16 U.S.C. $\$ 831 \mathrm{c}(\mathrm{f})(1970)$. This provision, similar to that vetoed by President Wilson in 1920, was later construed in Morgan v. T.V.A., 115 F.2d 990 (6th Cir. 1940), not to preclude removal by the President. The court, citing Springer v. The Philippine Islands, 277 U.S. 189 (1928), suggested that the Act would be of questionable validity if concurrent resolution were the only means of removal. 115 F.2d at 993. 
was the provision ${ }^{120}$ that would have empowered the Joint Committee on Internal Revenue Taxation to veto individual federal tax refunds in excess of $\$ 20,000$. The principal support for the objection to this provision, and to the provision for congressional disapproval in the reorganization act, was Springer v. The Philippine Islands, ${ }^{121}$ which the Attorney General had successfully argued as Solicitor General before the Supreme Court some five years before. ${ }^{122}$ This decision, based not on the Constitution but on the separation of powers provisions of the Philippine Organic Act, remains virtually the only federal judicial statement on limits to the governmental powers of legislators.

Springer was a quo warranto action wherem the Governor General of the Philippime Islands contended that an election of directors of two largely government owned corporations, the National Coal Company and the Philippine National Bank, had been illegal. The vote of government owned stock in each of these corporations was vested by statute in a committee consisting of the Governor General, the President of the Senate, and the Speaker of the House. ${ }^{123}$ The applicable law was the Philippine Organic Act of $1916^{124}$ establishing a government of three branches modeled after that of the United States, and providing that "all executive functions of the government must be directly under the Governor General or within one of the executive departments under the supervision and control of the Governor General."125 This Act bears a relation to the governmental affairs of the Philippines "not unlike that borne by a State constitution to the state,"128 and the Court, as a matter of interpretation and construction, dealt with the Act as if it were a State constitution. The Court began its analysis by noting that while the constitutions of some of the states "expressly provide in one form or another that the legislative, executive and judicial powers of the government shall be forever separate and distinct from each other,"127 that of the United States does not. Over the objection of Justice Holmes, joined by Justice Brandeis, ${ }^{128}$ the Court, citing Kil-

120. The bill was vetoed by President Hoover on the basis of the Attorney General's advice. 76 CONG. REC. $2445-46$ (1933).

121. 277 U.S. 189 (1928).

122. For someone with access to Mitchell's papers from this period, it would be interesting to learn whether the Springer case was brought to create a precedent which could later be used to attack extra-legislative congressional activity.

123. 277 U.S. at 198. The Philippine legislature had included similar provisions in the acts creating the National Petroleum Company, the National Development Company, the National Cement Company, and the National Irou Company. Id. at 199.

124. Act of Aug. 29, 1916, ch. 416, 39 Stat. 545.

125. Id. $\$ 22$.

126. 277 U.S. 189,200 (1928).

127. 277 U.S. at 201.

128. Id. at 209. 
bourn $v$. Thompson, ${ }^{129}$ stated that the principle expressed in the State constitutions was nevertheless identical to that controlling the Federal Government, and that this was the standard applicable to Springer. ${ }^{130}$ The consequence of this holding was that the Court's discussion, while actually concerued with Philippine law, serves also as an interpretation of the United States Constitution, albeit as dictum.

A significant feature of this case was the Court's definition of the legislative role: "[l]egislative power, as distinct from executive power" is "the authority to make laws, but not to enforce thein or appoint the agents charged with the duty of such enforcenent."131 The Court noted that the President of the Senate and the Speaker of the House were not serving in a legislative capacity on the committee, nor did their function have a judicial aspect. This sufficed in the present context for the Court to conclude that meinbers of the committee functioned in an executive capacity. ${ }^{132}$ While they were not appointed, they had these executive positions by reason of their positions in the legislature. The Court added that if the legislature, which was denied the appointment power, were allowed to engraft executive duties on legislative office, this would "usurp the power of appointment by indirection."188 Without deciding whether committee neinbers were public officers in a strict sense, the court considered them to be "public agents at least, charged with the exercise of executive functions and, therefore, beyond the appointing power of the legislature."13:t Read narrowly, the case lolds that the legislature can not place legislators, by appointment or otherwise, in positions where they would wield executive power. A broader niessage is also clear: the legislature is limited to lawmaking; it cannot enforce or execute the laws.

The Attorney General's invocation of Springer, and President Hoover's subsequent veto of the Urgent Deficiency Bill inarked a brief period of congressional retreat. Following the Hoover veto, Congress again considered a reorganization proposal. Attempts to include legislative veto provisions in the Bill were made in both Houses but failed;

129. 103 U.S. 168 (1880).

130. 277 U.S. at 201.

131. Id. at 202.

132. Id.

133. 277 U.S. at 202.

134. Id. at 203. Springer and Attorney General Mitchell's opinion based thereon, have constituted the bulwark of later attacks on the creation of extra-legislative congressional powers. See generally the sources subsequent to 1933 cited in note 9 supra.

The Springer Court went on to compare a Colorado case, Stockman v. Leddy, 55 Colo. 24, 129 P. 220 (1912). In Stockman the State legislature had established a commission to investigate and determine steps necessary to protect the State's water rights, but apparently not with an eye to legislation. The Colorado court found the act creating the study commission to be unconstitutional. If the Supreme Court's apparent approval of Stockman is taken seriously, it would seem to cast doubt even on some of 
debate indicated acceptance of the Attorney General's proposition that such power was properly exercised only with the concurrence of both Houses and opportunity for presidential veto. ${ }^{135}$ Title IV of the Treasury and Post Office Appropriation Act of $1934^{136}$ provided for a 60day delay in effectiveness, but Congress could disapprove the reorganization order during this period only by legislation..$^{137}$

This congressional reticence was short lived, however. In 1938, Congress attempted to pass another reorganization act. President Roosevelt actively supported a version which would allow effective disapproval of his proposals only by proper passage of a joint resolution, commenting: "Sucl1 a [concurrent] resolution cannot repeal Executive action taken in pursuance of a law." 138 The House, however, insisted upon inclusion of an authorization for disapproval by concurrent resolution, and the bill died in committee. ${ }^{139}$ Congress attacked reorganization with renewed vigor the following year. Pouncing upon a contemporary Suprene Court decision, Currin v. Wallace, ${ }^{140}$ supporters of a concurrent resolution provision in the 1939 reorganization bill ${ }^{141}$ analogized a congressional vote to the farmer vote allowed in Currin, considering it a mere contingency necessary to effectuate prior legislation. ${ }^{142}$ After much debate, the Reorganization Act of 1939, with provision for the rejection of the President's proposals by concurrent resolutions, ${ }^{143}$ was finally passed and signed by the President.

the more accepted congressional uses of commissions. Springer, however, distinguished the use of Congressmen on the Board of Regents of the Smithsonian Institution, attributing that use to the "peculiar character of the institution." 277 U.S. at 204.

135. 76 CONG. REC. $3537-40$ (1933).

136. Act of Mar. 3, 1933, cl. 212, $\S 407,47$ Stat. 1519. For a detailed discussion of the reorganization acts see Ginnane, supra note 13, at 576-82; HARRIs, supra note 12, at 206-10.

137. Act of Mar. 3, 1933, ch. 212, § 407, 47 Stat. 1519.

138. 83 CONG. REC. 4487 (1938).

139. See 83 CONG. REC. 5003-11, 5123-24 (1938).

140. 306 U.S. 1 (1939).

141. H.R. 4425, 76th Cong., 1st Sess. (1939).

142. See H.R. ReP. No. 120, 76th Cong., 1st Sess. 6 (1939). For a discussion and references to Congressional debate, see Ginnane, supra note 13, at 579-80; Millet \& Rogers, The Legislative Veto and the Reorganization Act of 1939, 1 PUB. ADMm. Rev. 176 (1941).

143. 53 Stat. 562 . Since the 1939 Act, legislative veto provisions have persisited in governmental reorganization authorizations. As it was originally reported by the Senate Committee on the Judiciary, the Reorganization Act of 1945 would have allowed disapproval by simple resolution, a provision identical to that to which Mr. Mitchell had objected. The Committee report urged: "Such a delegation of legislative power does not operate to deprive either House of the Congress of its constitutional right to have no change made in the law relating to organization of the Government without the assent of at least a majority of its Members present and voting." S. REP. No. 638, 79th Cong., 1st Sess. 3 (1945). Nevertheless, the 1945 act finally passed maintained the 1939 provision for concurrent resolution. Act of Dec. 20, 1945, ch. 582, \& 6, 59 Stat. 616. 


\section{b. World War II and Following-The Concurrent Resolution and Presidential Acquiescence}

The 1939 Reorganization Act heralded the beginning of an almost explosive increase in the use of concurrent resolution provisions as a ineans of controlling executive powers and actions. During the War years and into the early 1950's the device was used primarily to allow Congress to terminate statutory power given to the President or otherwise effectively repeal a statute. Congress' assumed powers ranged from the ability to repeal daylight savings time ${ }^{144}$ to the termination of the President's power under the Lend Lease Act. ${ }^{145}$

For the most part, early resolution provisions such as those establishing the right to repeal statutory powers, gave Congress only broad, generalized power over the executive. But there were exceptional situations where Congress reserved the power to exercise a much more detailed control over administrative decisions. One of the nnost noteworthy of these exceptions is the Alien Registration Act of $1940^{140}$ and subsequent related acts. ${ }^{147}$ These acts generally authorize the Attorney General to suspend deportation of particular aliens otherwise eligible for deportation. For certain classes of aliens, the acts require that

In 1949 Congress provided that a reorganization plan submitted by the President could be disapproved by a majority of the membership of either House. Act of June 20 , 1949, ch. $226, \S 6,63$ Stat. 205. While this legislation was under consideration, President Truman had recommended continuation of the concurrent resolution provision, H.R. REP. No. 23, 81st Cong., 1st Sess. 2 (1949), and the Attorney General submitted to Congress a memorandum disagreeing with former Attorney General Mitchell's "dictum" concerning the Reorganization Act of 1933. The Attorney General suggested that such legislation was in the nature of a contract between the President and Congress. The President, in signing the Act, undertook to consult with Congress before utilizing the authorized power, and to carry out a reorganization plan only if members of Congress did not object. S. Rep. No. 232, 81st Cong., 1st Sess. 20 (1949). In 1957 the language of the 1949 Act requiring vote of a majority of the membership was removed, so that a simple majority of those voting would suffice for disapproval. Act of Sept. 4, 1957, Pub. L. No. 85-286, 71 Stat. 611.

The Defense Reorganization Act of 1958, Pub. L. No. 85-599, 72 Stat. 514, seems to be the only reorganization act in recent years to have evoked a presidential response. That Act authorized the Seeretary of Defense to submit plans for reorganizing the military directly to Congress, without providing for presidential oversight. The Secretary's plan was subject to disallowance by vote of either House. 1d. $\$ 3,72$ Stat. 515. In signing the Act President Eisenhower made clear that he had instructed the Secretary to subunit to him any reorganization plans. HARRus, supra note 12, at 210.

144. Act of Jan. 20, 1942, ch. 7, § 2, 56 Stat. 9.

145. Act of Mar. 11, 1941, ch. 11, \& 3(c), 55 Stat. 32. For a discussion of the statutory provisions of this era, see Ginnane, supra note 13, at 582-92; White, Executive Responsibility to Congress Via Concurrent Resolutions, 36 AM. Pol. ScI. REv. 895 (1942). For a compilation of statutes authorizing control by resolution, see Appendix A.

146. Ch. 439,54 Stat. 67.

147. Act of July 1, 1948, ch. 783, 62 Stat. 1208; Act of June 27, 1952, ch. 477, \$ 244(5)(b), (c), 66 Stat. 216. 
the deportation proceed unless the suspension is approved by concurrent resolution. In other cases, Congress can disapprove particular suspensions by simple resolution and thus order deportation. Another exception, the Federal Airport Act ${ }^{148}$ allows congressional disapproval of particular airport projects, a function characteristic of Congress' later use of the committee veto. Following a decline in use of simple and concurrent resolution provisions in the 1960 's, the 1970's have seen a resurgence of the devices in a much broader range of use. ${ }^{149}$ The measures have been used to control specific executive activities, and have been increasingly used to retain congressional control over administrative rulemaking. ${ }^{150}$

Prior to World War II presidential opposition had been important in limiting use of concurrent resolutions. During the period between the World Wars, Congress had begun to show increasing imterest in the concurrent resolution as a means of exercising non-legislative power. Yet, each time Congress had attempted to make use of the device, it had met with opposition. President Wilson had vetoed the provision permitting removal of the Comptroller General, ${ }^{151}$ and criticism of a prior reorganization act by Attorney General Mitchell, advising Hoover to veto the Urgent Deficiency Act, had caused Congress to remove a concurrent resolution provision from the 1934 act. ${ }^{152}$ President Roosevelt made no such stand against the device. Although he had indicated a dislike for such provisions in his 1938 comments to Congress on the proposed reorganization act, ${ }^{153}$ he signed the Lend Lease Act and other concurrent resolution provisions in silence.

Only subsequent to the work on control of administration by resolutions and committees by Robert W. Ginnane, ${ }^{154}$ then of the Solicitor General's office, was Roosevelt's attitude on these provisions revealed. In an unprecedented but hittle noted article in Harvard Law Review, ${ }^{155}$ Justice Jackson, inspired by Ginnane's work, published "a presidential legal opimion" submitted for safekeeping by the President to Mr. Jackson during the latter's tenure as Attorney General. ${ }^{156}$

The President's confidential opimion was formnlated in response

148. Ch. 251, § 8, 60 Stat. 174.

149. See note 145 , supra.

150. See Ginnane, supra note 13 , at 577.

151. See note 103 supra.

152. See note 123 supra.

153. See note 138 supra.

154. See note 13 supra.

155. Jackson, A Presidential Legal Opinion, 66 HaRv. L. Rev. 1353 (1953). The failure of a number of commentators to note this work may be due to the failure of Shepard's to include it among the sources citing Ginnane's article.

156. The text of the President's memorandum is reproduced in Justice Jackson's article. Id. at 1357-58. 
to congressional passage of the Lend Lease Act, which Mr. Roosevelt considered "constitutionally objectionable but politically necessary."157 The concurrent resolution provision in the Lend Lease Act had been sponsored by the President's supporters as an inducement for Congress to grant extraordinary powers. Roosevelt, who apparently had not assented to the provision, shared the view of his political enemies that the provision was unconstitutional; but le felt that public relevation of his views would result in loss of vitally needed support. ${ }^{168}$ At the same time the President foresaw the possibility of having to challenge the constitutionality of the provision and force Congress to override his veto in order to revoke his powers. "[H]e wanted a record that his constitutional scruples did not arise only after the shoe began to pimch, and, so far as possible, to excuse his approval and counteract its effect. He did not want the precedent created by lis yielding to ripen into a custoin which would impair the powers which properly appertained to his great office." 159

Notwithstanding Mr. Roosevelt's privately expressed doubts, his acquiescence in the use of concurrent resolutions during the war was continued by President Truman and his successors. Use of resolutions, simple and concurrent, has spread beyond the termination of statutory authority, and has become fairly common, with only occasional presidential protest. ${ }^{160}$

157. Id. at 1353 .

158. Id. at 1356-57.

159. Id. at 1357 .

160. For an indication of the uses made of concurrent and simple resolutions, see the compilation in Appendix A. President Eisenhower criticized but signed a defense reorganization act which contained a provision for disapproval by resolution, see note 142 supra, and President Nixon vetoed the War Powers Resolution, 87 Stat. 555 (1973), claiming its provision for a concurrent resolution to direct the President to disengage from hostilities not entered into with statutory authority was unconstitutional. 9 WEEKLY COMP. PRES. Doc. 1285 (Oct. 24, 1973). Congress overrode the President's veto. 119 CoNG. REc. H9641-61, S20093-116 (daily ed., Nov. 7, 1973). Later, President Nixon approved without comment the Emergency Petroleum Allocation Act of 1973, Pub. L. No. 93-159, 87 Stat. 627, which allowed Congress to veto proposed changes in Federal regulations concerning oil products. It was reported that the President disapproved of a provision for congressional disapproval of energy conservation plans ordered pursuant to a subsequent energy bill, H.R. 11450, 93d Cong., 1st Sess. (1973). See N.Y. Times, Dec. 20, 1973, at 1, col. 6.

However, it appears that his objections in this case were not founded on principle. While the President objected to the particular disapproval provisions adopted by the conference committee, he had in fact sought authority to institute emergency plans subject to congressional veto by simple resolution within 15 days. See 31 Cong. QUART. 3335, 3355 (1973). When the President eventually vetoed the corresponding Senate bill, S. 2589 , the provisions for legislative veto were not among his enumerated reasons. 120 CONG. REC. S2883 (daily ed., Mar. 6, 1974).

In his veto of the Atomic Energy Act Amendments of 1974, H.R. 15323, 93d Cong., 2d Sess. (1974), President Ford objected to a new use of the concurrent resolu- 


\section{c. The Postwar Rise of the Committee Veto and Presidential Opposi- tion}

In marked contrast to executive acquiescence to the use of resolutions, Presidents since Roosevelt have vigorously opposed use of the committee veto. Formal committee control over administration had been disapproved by Presidents Wilson and Hoover, and President Roosevelt's opposition to such measures was clear from his veto of the New York World's Fair Commission. ${ }^{161}$ Yet, like the concurrent resolution, modern use of committee control seems to find its roots in World War II during the Roosevelt Administration. Control by committee developed more slowly than did control by resolution, but it has flourished nevertheless. ${ }^{162}$

While the primary purpose of resolutions was to give broad powers of control over the executive to Congress, committee control was used predominantly to supervise spending for particular projects. Committees often were given final say in public construction projects and in disposal or acquisition of military property. The earliest of these provisions, enacted during World War II, did not establish formal committee veto power; rather it facilitated control at an informal level. Such "informal committee vetoes," which have persisted and remain quite common, typically were established by a statute authorizing administrative action, but requiring the administrator to report to a committee in advance of any proposed action. Often there was a specified waiting period before the proposed action could be taken. Thus the Act of March 26, 1943, passed during Roosevelt's administration, re-

tion. In that bill the President was asked to sign "into law" an act which would take effect at a later date, and then only if Congress had not announced by concurrent resolution that it should not take effect at all. The President termed the provision "merely the expression of an intent to legislate," and stated:

The presentation of a bill to me pursuant to Article $\mathrm{I}$, section 7 of the Constitution amounts to a representation by Congress that, as far as it is concerned, the legislation is ready to become effective, subject perhaps to some extrinsic condition precedeut, but not to further congressional deliberation. Here, however, Congress in effect requests my approval before it has given its own.

In this instance, the clear constitutional infirmity of the bill not only affects my powers and duties but directly endangers substantial and important private rights. ... .

10 WERKLy COMP. PRes. Docs. 1279 (Oct. 12, 1974).

In January $1975 \mathrm{Mr}$. Ford signed into law a simple resolution provision which would give either House of Congress power to override not an executive action, but amendments to the Federal Rules of Evidence which might be promulgated by the Supreme Court. Act of Jan. 2, 1975, Pub. L. No. 93-595, § 2, 88 Stat. 1926. A number of other provisions for congressional resolution have escaped comment by Mr. Ford. See Appendix A.

161. See note 131 supra.

162. For a compilation of statutes in which Congress has bestowed formal powers on a committee, see Appendix B. 
quired that "the Secretary of the Navy shall report to the Senate and the House Naval Affairs Committees all . . . prospective acquisitions" of land under the authority of the act. ${ }^{163}$ In theory, disapproval of the proposed actions could only be effectuated by legislation, ${ }^{104}$ but in practice there is little doubt that this provision gave the committees veto power over acquisitions. ${ }^{165}$

Informal coinmittee veto provisions in the form of "report and wait" clauses remain more numerous than instances of formal committee veto power. On occasion, lowever, Congress has not been satisfied with the informal provisions, and has pressed for acceptance of formal committee powers. In 1944 the reporting provision in an act authorizing acquisition of naval property was changed to a requirement that the Secretary of the Navy "come into agreement" with the committees before acquisition or disposal of property. ${ }^{166}$ This "come into agreement" clause passed President Roosevelt without apparent note, but a short time later Roosevelt protested a related provision requiring consultation with the Senate and House Naval Affairs Committees regarding the details of a proposed contract dealing with Naval oil reserves before execution thereof. The President, contending that the provision for consultation would vest Congress with "what amounts to executive powers over the administration of the Naval petroleum reserves,"107 stated:

I would have considered [this requirement] unwise enough if it had merely placed the executive function of advising and consulting on contracts and leases in the hands of the two Houses of the Congress. But to go further and to delegate, as it were, this function to two committees of the Congress is, in my opimion, to disregard principles basic to our form of government.

Efficient and economical administration can be achieved only by vesting authority to carry out the laws in an independent executive and not in legislative committees. This act, in my opinion, impinges

163. 57 Stat. 52. The Act was approved by President Roosevelt without comment.

164. See 89 CoNG. REC. 1218 (1943) (remarks of Reps. O'Connor and Maas).

165. See id. at 1229 (remarks of Rep. Maas). A provision requiring an administrator to report a proposed action to Congress and wait a specified period before so acting is clearly proper if its purpose is to allow time for a legislative response by Congress. This procedure has been followed in the case of the Federal Rules of Evidence and the Federal Rules of Civil Procedure. See Act of Mar. 30, 1973, Pub. L. No. 93-12, 87 Stat. 9. Much more problematical is the use of "report and wait" provisions where the intent and practice is not to allow time for legislation, but to allow an effective committee veto. Though "report and wait" provisions are currently much more numerous than formal committee veto provisions, this section will concentrate on the formal provisions. The informal provisions are discussed again in section IV.

166. Act of Apr. 4, 1944, ch. 162, 58 Stat. 189, 190.

167. 90 CONG. REC. 6154 (1944) (quoting Mr. Roosevelt's remarks as reproduced in a New York Times article of June 18, 1944). 
deeply upon this fundamental principle of good government embodied in the Constitution. ${ }^{168}$

Roosevelt nevertheless signed the bill. ${ }^{169}$

There were no confrontations over the committee veto during the early years of the Truman administration. In 1949, however, Congress sought to regain some of the control over government printing which it had exercised under the 1919 act $^{170}$ before losing it through the development of alternative reproduction techniques. The act closing the loophole ${ }^{171}$ through which the administration had escaped control was signed by Mr. Truman, who later objected to "the invasion of the rights of the Executive branch by a legislative committee."172 In 1950 the President submitted substitute legislation on which Congress took no action. ${ }^{173}$

Another act passed in 1949 required the military to "come into agreement" with the Armed Services Committees before acquiring land for use as a guided missile proving ground. ${ }^{174}$ This passed without apparent note; but a 1951 military construction authorization bill ${ }^{175}$ covering a much broader range of real estate transactions raised greater controversy and finally brought the constutionality of committee control into debate. In defending a "come into agreenent" provision in this bill, Representative Carl Vinson had in 1949 stated:

Well, I think it is a fine control. I want this committee to have something to do with running the departments instead of the departments just telling the committee what they are going to do . . . .

[W] hen we are guiding the destinies of the Navy we felt that the committee should have a hand in a great many things. ${ }^{176}$

President Trnman vetoed the bill, coinplaining of the administrative inefficiencies it would foster, and adding:

I am concerned by what appears to me to be a gradual trend on the part of the legislative branch to participate to an ever greater extent in the actual execution and administration of the laws. Under our system of government it is contemplated that the Congress will enact the laws and will leave their administration and execution to the executive branch. ${ }^{177}$

168. Id.

169. Act of June 17, 1944, ch. 262, 58 Stat. 280, 281.

170. See note 94 supra.

171. Act of July 5, 1949, ch. 296, 63 Stat. 405.

172. HARRIS, note 12 supra, at 218.

173. Id.

174. Act of May 11, 1949, ch. 98,63 Stat. 66 .

175. H.R. 3096, 82d Cong., 1st Sess. (1951). This provision covered transactions involving more than $\$ 15,000$.

176. Hearings on the Organization of the Armed Services Committee before the House Committee on Armed Services, 81st Cong., 1st Sess. 10 (Jan. 25, 1949).

177. 97 CONG. Rec. 5374-75 (1951). 
During the debate preceding the 312 to 68 House override, Representative Vinson defended the provision as a mere delegation of authority which could as well be made to a congressional committee as to a bureau. Vinson argued further that such power was authorized by article $I V$, section 3 of the Constitution, granting Congress the power to "dispose of and make all needful rules and regulations respecting property belonging to the United States."178 In opposition to the provision, several congressmen attacked the constitutionality of committee control. Representatives Miller and Tacket complained that the provision allowed Congress to administer the laws it enacts, ${ }^{170}$ while Wright Patman argued that if the disapproval power to be vested in the committees was a legislative function it could be performed only by the two Houses; if it was an executive function it could not be performed by a legislative comittee. ${ }^{180}$ Despite the overwhelming House override, the Senate took no action on President Truman's veto.

The President's victory was short-lived, however. Only a few months after the successful veto, a provision was attached to another military construction bill identical to that vetoed, but applicable only to transactions in excess of $\$ 25,000 .{ }^{181}$ Because of the urgent need for the legislation, the President signed the bill. ${ }^{182}$ The following year an act requiring cominittee approval of the cost of military construction projects and related real estate transactions was signed into law without comment. ${ }^{183}$ The President, however, pocket vetoed a bill which would have required the Postmaster General to "conte into agreement" with the Senate and House Public Works Committees as a condition precedent to consumating lease-purchase contracts for construction of post offices. ${ }^{184}$ On one occasion during the Truman administration the legislature succeeded in giving formal veto power over administrative action to a single member of Congress. The Supplemental Appropriation Act for $1953^{185}$ gave the regulations of the Bureau of the Budget relating to housing allowances the effect of law, and provided that these regulations could be amended only with the approval of the Chairman of the House Appropriations Committee. The provision was later repealed at the urging of President Eisenhower. ${ }^{186}$

178. Id. at 5437 (1951).

179. Id. at 5437-41 (1951).

180. Id. at 5443 (1951).

181. Act of Sept. 28, 1951, ch. 434, $\$ 601,65$ Stat. 336, 365.

182. HARRIS, supra note 12, at 222.

183. Act of July 14,1952 , ch. $726, \S 407,66$ Stat. 606,625 .

184. 98 CoNG. REC. 9756 (1952) (presidential letter explaining the veto of H.R. 6839, 82d Cong., 2d Sess.).

185. Act of July 15, 1952, ch. 758, § 1413, 66 Stat, 637, 661.

186. See HARRIS, supra note 12 , at 225. 
By the end of the Truman administration, use of the formal committee veto had established a foothold in a very narrow area of the law-control over the acquisition and disposition of military property. ${ }^{187}$ When President Eisenhower took office, however, he reinvigorated presidential opposition to committee control, making no exception for the disposal of military real estate. Supported by the Task Force on Real Property Management of the second Hoover Commission, ${ }^{188}$ Eisenhower steadfastly opposed committee control over real estate transactions authorized by Congress. In 1954 the President was sustained in his veto of a bill which would have authorized the transfer of federal lands within Camp Blanding Military Reservation to the state of Florida upon agreement between the Secretary of the Army and the Armed Services Committees. The President stated:

The practical effect would be to place the power to make such agreement jointly in the Secretary of the Army and the members of the Committee on Armed Services. In so doing, the bill would violate the fundamental constitutional principle of separation of powers prescribed in articles I and II of the Constitution which place the legislative power in the Congress and the executive power in the executive branch.

The making of such a contract . . . is a purely executive or administrative function ..... [Congress] may not delegate to its members or committees the power to make such contracts, either directly or by giving to them a power to approve or disapprove a contract which an executive officer proposes to make. Moreover such a procedure destroys the clear lines of responsibility which the Constitution provides. ${ }^{189}$

After the veto of the 1954 Camp Blanding Bill, Eisenhower continued to resist new committee control provisions dealing with real estate transactions. ${ }^{190} \mathrm{He}$ also took the offensive against a committee

187. Introduced in the waning phase of World War II, the device, according to Professor Harris, was applied predominantly to the disposition of installations and land no longer needed:

The requirement of advance approval by congressional subcommittees enables members of Congress to resist the closing of military installations in their districts, and it cannot be doubted that the effect is to force the retention of installations that in the interest of economy should be closed.

HARRIS, supra note 12 , at 223.

188. Commission ON ORganization of the Executive Branch of the Government, Real Property Management 35-36 (1955); TASK Force Report, ReaI PropERTY MANAGEMENT 92-94 (1955).

189. 100 CONG. REC. 7135 (1954).

190. In 1956 Congress attached "come into agreement" provisions to legislation authorizing the construction of military housing and facilities for the Talos Missile program. The President vetoed the bill. 102 Cong. Rec. 12958-59 (1956). Congress was forced to utilize a "report and wait" provision to accomplish its purpose. Act of Aug. 3, 1956, ch. 939, \& 419, 70 Stat. 991, 1018-19. 
control provision he had inherited from his predecessor, the "come into agreement" provision of the Military Construction Act of $1951 .{ }^{101}$ Following the recommendation of the Hoover Commission, ${ }^{102}$ the President sought to have this section of the law repealed. After several unsuccessful attempts, Eisenhower finally threatened to direct the Secretary of Defense to "disregard the section unless a court of competent jurisdiction determines otherwise."103 To avoid the threatened confrontation, Congress replaced the offending provision with a "report and wait" requirement. ${ }^{104}$

Despite Eisenhower's resistence to formal committee control over land transactions, Congress attempted to expand committee power into other admimistrative areas. Following the 1952 elections, the administration initiated a "decompetition program" intended to end Department of Defense participation in various "enterprises" through which the government competed with private business. This program threatened to close military commercial facilities and create unemployment in the districts of several influential Congressmen. ${ }^{105}$ To prevent this, Congress attached a rider to a defense appropriation bill requiring cominittee approval of such closings. ${ }^{108}$ Relying primarily on Springer and Attorney General Mitchell's 1933 opinion, ${ }^{107}$ Attorney General Brownell advised the President that the rider was unconstitutional but separable from the rest of the act. ${ }^{108}$ Although he signed the bill, Eisenhower announced that the executive branch would regard the rider as invalid unless determined to be otherwise by a court of competent jurisdiction. ${ }^{100}$ Nevertheless, the Comptroller General assured the Congress that he would enforce the law and disallow any expenditure pursuant to the act which did not gain committee approval. The consequence of disallowance was that the signer of an unauthorized check became personally liable for payment. The Defense Department adhered to the committee approval provision. ${ }^{200}$ The following year the provision

191. See note 181 supra and accompanying text.

192. See note 188 supra. Acting Attorney General Rogers also advised the President that the provision was unconstitutional. 41 OP. ATT'Y GEN. 300 (1957).

193. Budget Message of the President for Fiscal 1961, H.R. Doc. No. 255, 86th Cong., 2d Sess. M18 (1960).

194. Act of June 8, 1960, Pub. L. No. 86-500, $\$ 2662,74$ Stat. 166, 186-87. See H.R. REP. No. 1307, 86th Cong., 2d Sess. 43-45 (1960).

195. The most fateful of the threatened closings was undoubtedly that of the "ropewalk" in Boston. This factory of rope and sable for the Navy since 1834 was loccated in the district of House Majority Leader McCormack. See discussion in HARRIS, supra note 13 , at 226-30.

196. 69 Stat. 301,321 (1955).

197. See note 119 supra.

198. 41 OP. ATT'Y GEN. 230 (1955).

199. Public Papers of the Presidents: DWight D. Eisenhower, 1955, at 688.

200. HARRIS, supra note 13, at 229. 
which had given veto power to the House Appropriations Committee was dropped in anticipation that corresponding power would be given to the Armed Services Committees. The new bill failed to pass the Sentate, and the provision died. ${ }^{201}$

Congress was more successful in asserting commitee control over public construction projects, despite initial opposition on constitutional grounds from within Congress itself. In 1954, the Senate Public Works Committee attempted to insert into a bill a "come into agreement" requirement for the construction of post offices. This same requirement had earlier met a pocket veto from President Truman. ${ }^{202}$ The "come into agreement" clause met vigorous opposition, primarily from Senator Dirksen, who stated:

[T] $]$ is measure, in its present form, would . . . vest in two committees of the Congress a function which the Constitution does not sanction. It gives two committees a veto over actions of the executive branch which have been authorized by congressional enactment. Nowhere in the Constitution is mention made of committees of the Congress. . . . [T] he only authorized Congressional action is action by both Houses of Congress and not by its committees. ${ }^{203}$

In response to the Senator's opposition, a new form of committee control was devised. The bill finally signed by the President ${ }^{204}$ specified that no funds should be appropriated for annual payments in excess of $\$ 20,000$ on any post office lease-purcliase contract unless prior approval had been given by the Public Works Committee. ${ }^{205}$ Thus the restriction was directed not at the executive, but at Congress. A similar provision for committee approval of "works of improvement" prior to appropriation was included in the Watershed Protection and Flood Prevention Act of $1954,{ }^{206}$ and was signed without comment. Spurred by presidential acceptance, this device quickly caught on in the area of public construction. ${ }^{207}$

201. Id. at 230. The provision had originally been attacked as unconstitutional by none other than Carl Vinson, the leading proponent of the committee veto in the Armed Services Committees. Id, at 228.

202. "I . . . question the propriety and wisdom of giving committees the veto power over executive functions . . . ." 98 CONG. REc. 9756 (1952).

203. 100 CoNG. REC. 5095 (1954).

204. According to Professor Harris, Eisenhower signed the bill on the advice of his Attorney General that the provision was within the power of Congress. HARRus, supra note 13, at 231. Some time later the Attorney General approved the provision in retrospect. 41 OP. ATT'Y GEN. 300, 305 (1957).

205. Act of July 22,1954 , ch. $560, \S 411,68$ Stat. $518,519$.

206. Act of Aug. 4, 1954, ch. 656, § 2, 68 Stat. 666 .

207. Examples of "no appropriation" provisions may be found in the following acts: Act of May 22, 1970, Pub. L. No. 91-265, $\$ 7,84$ Stat. 263 (amend the National Traffic and Motor Vehicle Safety Act of 1966-no appropriation for research and test 
The "no appropriation" provision was not always considered adequate in practice, however. While an appropriation by Congress in the face of a "no appropriation" provision would presumably repeal the latter to the necessary extent, an appropriation bill including an unapproved project would be subject to point of order on the floor. ${ }^{208}$ Thus, failure to obtain approval of any one of the inany projects in an appropriation bill for which approval might be required could halt the progress of the entire bill. To deal with this problem, Congress in the Small Project Reclamation Act of $1956^{209}$ once again provided for committee action subsequent to final congressional action. The Act authorized an admimistrator to negotiate a contract, but allowed committee disapproval of the negotiated contract prior to its execution. The President signed the Act, but announced that he would not carry out its provisions until the committee veto was reunoved. ${ }^{210}$ During its next session Congress replaced the formal committee veto with a "no appropriation" provision. ${ }^{211}$

Later, Congress included a "no appropriation" provision in the Public Buildings Act of 1959, but it too proved awkward in practice. The Act provided that "no appropriation shall be made to construct any public building . . . if such construction . . . has not been approved by resolutions adopted by the Committee on Public Works of the Senate and House of Representatives, respectively." ${ }^{212}$ The required procedure led the General Services Administration into embarassing difficulties as points of order on appropriation legislation were sustained, halting the consideration of necessary bills. The General Services Admimistration appealed to the Senate, asking that the annual appropriation under the authority of the Public Buildings Act be amended to allow committee approval subsequent to appropriation-the standard form of

facilities before committee approval); Agricultural Act of 1970, Pub. L. No. 91-524, $\S$ 801(9), 84 Stat. 1380-81 (no appropriation for agreement regarding retirement of cropland where federal cost exceeds $\$ 250,000$ unless approved by committee); Public Buildings Amendments of 1972, Pub. L. No. 92-313, 86 Stat. 217 (no appropriation for certain public building expenditures without committee approval); Consumer Product Safety Act, Pub. L. No. 92-573, \& 32(b)(1), 86 Stat. 1233 (no appropriation for planning or construction expenditure in excess of $\$ 100,000$ for research and testing facilities without committee approval).

208. See Hearings before the Subcommittee of the Senate Committee on Appropriations, Independent Offices Appropriation 1961, 86th Cong., 2d Sess., 153 (1960).

209. 70 Stat. 1045.

210. Public Papers of the Presidents: Dwigrt D. Eisenhower, 1956, at 648. The President's objection was noteworthy in that it was the first to suggest that the unconstitutionality of an act resulted not only from its invasion of the sphere of the executive, but also as an invalid delegation of legislative power to a committee.

211. Act of June 5, 1957, Pub. L. No. 85-47, 71 Stat. 4\&, 49.

212. Pub. L. No. $86-249, \& 7,73$ Stat. 479,480 (1959). 
the formal committee veto. ${ }^{213}$ Congress adopted this suggestion, ${ }^{214}$ and by 1964 the committee veto provision in appropriations under the Public Buildings Act of 1959 lad become boilerplate and was regularly given presidential approval without hesitation. ${ }^{215}$

213. "Acceptance of this principle should tend to avoid points of order . ..." Hearings Before the Subcommittee of the Senate Committee on Appropriations, Independent Offices Appropriation 1961, 86th Cong., 2d Sess. 153 (1960).

In Maiatico v. United States, 302 F.2d 880 (D.C. Cir. 1962), the court considered whether a particular acquisition required committee authorization. Neither the court nor the Governnent questioned the validity of the provision. The court rejected the Government's contention that the acquisition was authorized by subsequent appropriations legislation. The decision prompted Congress in 1962 to ratify prior transactions which had not followed the strictly authorized procedure. Act of Oct. 3, 1962, Pub. L. No. 87-741, 76 Stat. 716, 727. See H.R. REP. No. 2050, 87th Cong., 2d Sess. 1213 (1962).

214. Act of July 12, 1960, Pub. L. No. 86-626, 74 Stat. 425, 431.

215. See Act of July 12, 1960, Pub. L. No. 86-626, 74 Stat. 425, 431; Act of Sept. 8, 1960, Pub. L. No. 86-722, 74 Stat. 821, 826; Act of Aug. 17, 1961, Pub. L. No. 87141, 75 Stat. 342, 352; Act of Oct. 3, 1962, Pub. L. No. 87-741, 76 Stat. 716, 727, 728; Act of Dec. 19, 1963, Pub. L. No. 88-215, 77 Stat. 425, 436, 437; Act of Aug. 30, 1964, Pub. L. No. 88-507, 78 Stat. 640, 655; Act of Aug. 16, 1965, Pub. L. No. 89-128, 79 Stat. 520, 530-31; Act of Sept. 6, 1966, Pub. L. No. 89-555, 80 Stat. 663, 674; Act of Nov. 3, 1967, Pub. L. No. 90-121, 81 Stat. 341, 348-49; Act of June 19, 1968, Pub. L. No. 90-350, 82 Stat. 190, 194; Act of Oct. 4, 1968, Pub. I. No. 90-550, 82 Stat. 937, 944; Act of Sept. 26, 1969, Pub. I. No. 91-74, 83 Stat. 116, 120; Act of Nov. 26, 1969, Pub. L. No. 91-126, 83 Stat. 221, 228-29; Act of Sept. 26, 1970, Pub. L. No. 91-422, 84 Stat. 872, 876; Act of Dec. 17, 1970, Pub. I. No. 91-556, 84 Stat. 1442, 1448 1449; Act of July 9, 1971, Pub. I. No. 92-49, 85 Stat. 108, 119, 121; Act of July 13, 1972, Pub. I. No. 92-351, 86 Stat. 471, 484.

Not until 1972 was presidential objection to the procedure under the Public Building Act raised. In signing the Second Supplemental Appropriations Act of 1972, Pub. L. No. 92-306, 86 Stat. 163, President Nixon announced that he had been advised by the Attorney General that the "coming into agreement" provision contained in an appropriation under the Public Buildings Act of 1959 was unconstitutional, and that he would submit a budget amendment to renedy the constitutional problen1. The President stated:

... The bill appropriates definite sums for three public buildings projects but conditions the availability of the appropriation on the approval by the committee on public works of revised prospectuses for these buildings.

Under the Public Buildings Act of 1959, no appropriations may be nuade for public building projects until the public works committees have approved GSA's prospectuses for such buildings. The Congress regards this "no appropriation may be made" provision, I understand, as internal Congressional rule-n1aking not affecting the executive branch, and this Administration has acquiesced in that construction.

On the other hand, H.R. 14582 makes an appropriation to the General Services Administration but then conditions its use by GSA on that agency's getting the approval of the public works committees on revised prospectuses. This reversal of the normal Public Buildings Act procedure is found by the Attorney General to be an unconstitutional "coming into agreement" provision.

8 WeEkLY COMP. Pres. Docs. 938 (May 28, 1972). Only three weeks later Congress amended the Public Buildings Act itself to include a committee veto. Act of June 14, 1972, Pub. L. No. 92-313, 86 Stat. 216, 220. Again the President responded, announcing that the provisions he regarded as unconstitutional would be disregarded. 8 WEEkLY COMP. PRes. Docs. 1076 (June 16, 1972). 
There was little controversy over committee exercise of substantive powers during the Kennedy administration. Without objection, Kennedy approved "no appropriation" provisions ${ }^{210}$ as well as provisions for "consultation" concerning naval oil shale-statutory language remarkably similar to that earlier the subject of President Roosevelt's displeasure. ${ }^{217}$ President Kennedy also approved the Trade Expansion Act which, while not containing a committee veto provision, required the President to appoint members of Congress as delegates to certain trade negotiations. ${ }^{218}$ Kennedy even proposed a formal committee veto over an agricultural program. In his budget message of 1961 the President proposed that the administration be authorized to formulate an agricultural program which, following approval of two-thirds of the affected farmers, would be subject to committee veto. ${ }^{210}$ The proposal was not adopted by Congress.

On only one occasion did Kennedy object to a committee control provision. The Foreign Aid and Related Agency Appropriation Act of 1963 allowed committee veto of proposed uses of appropriated but unobligated funds. ${ }^{220}$ In a memoranduin to the admistrator of the Agency for International Development, Kennedy noted that he had been advised by the Attorney General that the provision was unconstitutional. Expressing concurrence with the views of Roosevelt, Truman, and Eisenhower on the formal committee veto, Kennedy directed the admimistrator to treat the provision as a simple "report and wait" requirement. ${ }^{221}$

Like Eisenhower, President Johnson actively opposed the use of formal committee vetoes, though he never commented on their use in the Public Building Act appropriations discussed earlier. ${ }^{222}$ Johnson also opposed the "no appropriation" device and, in some cases, forms of informal committee approval, all of which Eisenhower had tolerated. One example of Johnson's reaction to a formal committee veto involved the Agricultural Trade Development and Assistance Act of 1964. This

However, later the same year, Mr. Nixon signed without comment another amendment to the Public Buldings Act containing a committee veto provision for approval of details of the Dwight D. Eisenhower Memorial Bicentennial Civic Center. Act of Oct. 21, 1972, Pub. .L. No. 92-520, 86 Stat. 1019, 1021.

216. E.g., Act of Aug. 9, 1962, Pub. L. No. 87-578, 76 Stat. 335, 338 (appropriation of Indian funds); Act of Sept. 27, 1962, Pub. L. No. 87-703, 76 Stat. 605, 608 (approval of agricultural loans to local agencies).

217. Act of Oct. 11, 1962, Pub. L. No. 87-796, 76 Stat. 904.

218. Act of Oct. 11, 1962, Pub. L. No. 87-794, $\$ 243,76$ Stat. 878.

219. Public Papers of the Presidents: JoHn F. Kennedy, 1961, at 192, 196. See note 13 supra.

220. Act of Oct. 23, 1962, Pub. L. No. 87-872, 76 Stat. 1163, 1164 (1962).

221. Public Papers of the Presments: John F. KenNedy, 1963, at 6.

222. See note 215 supra. 
Act authorized the Senate Committee on Agriculture and Forestry and the House Committee on Agriculture to exercise veto power over certain grants of foreign currency proposed by the administration and otherwise authorized by law. ${ }^{223}$ While President Johnson signed the Act, he also expressed constitutional objections to the veto provision and announced that he would treat it as an accounting provision only. ${ }^{224}$

President Johnson also resisted no appropriation provisions on several occasions. Three nronths before expressing his objections to the Agricultural Trade Developnent and Assistance Act of 1964, he requested deletion of a "no appropriation" provision in the Water Resources Research Act of $1964,{ }^{225}$ but acknowledged that the Act was so phrased as not to be technically unconstitutional. ${ }^{226}$ The following year, Johnson vetoed the Pacific Northwest Disaster Relief bill, ${ }^{227}$ which also contained a "no appropriation" provision. We analogized the provision to a "coine into agreeinent" requirenent, stating: "I must oppose the tendency to use any device to imvolve congressional commitees in the administration of programs and the implenientation of laws." ${ }^{28}$ The President indicated that he would sign the bill immediately upon deletion of the objectionable provision. ${ }^{229}$

Later in 1965, Johnson signed the Ommibus Rivers and Harbors bill ${ }^{230}$ in spite of a provision that "No appropriation shall be made to construct, operate, or maintain any such project [certain water resource developinent projects] if such project has not been approved by resolutions adopted by the Committees on Public Works of the Senate and House of Representatives, respectively." "231 Instead of vetoing the bill, which he termed an "infringement upon the office of the Presi-

223. Act of Oct. 8, 1964, Pub. L. No. 88-638, § 8, 78 Stat. 1035, 1036 (1964).

224. Public Papers of the Presidents: Lyndon B. Johnson, 1963-1964, at 124951.

225. Act of July 17,1964 , Pub. L. No. $88-379$, $\$ 104,78$ Stat. 329,331 . The statute was later amended to replace the "no appropriation" provision with a "report and wait" provision. Act of Apr. 19, 1966, Pub. L. No. 89-404, § 200, 80 Stat. 129, 130.

226. Public Papers of the Presidents: Lyndon B. Johnson, 1963-1964, at 86162.

227. S. 327, 89th Cong., 1st Sess. (1965).

228. 111 CoNG. ReC. 12639 (1965).

229. Id. This bill, greeted with a more strident tone by the President than was the Water Resources Research Act, is perhaps distinguishable from the latter. The earlier act had authorized an appropriation but had limited that authorization by requiring committee approval before actual appropriation was to be made. The relief act, on the other hand, utilized a "back-door spending" device. It purported to authorize the executive to perform certain work, but disallowed any appropriation for such work except as approved by a particular committee prior to a specified date. Id.

230. S. 2300, 89th Cong., 1st Sess., 79 Stat. 1073 (1965).

231. Public Papers of the Presdents: Lyndon B. Johnson, 1965, at 1082-83. 
dency," the President noted that it was a grant of authority not requiring that action be taken, and stated that no action would be taken prior to the provision's repeal. ${ }^{232}$ Congress declined to act on the President's request for repeal, and funds appropriated under the bill remained impounded until released by President Nixon in 1969. ${ }^{238}$

Johnson also seems to have been the only President to have opposed the "report and wait" requirement-in practice an informal committee veto provision. The Military Construction Authorization Act of $1966^{234}$ required that the President report any proposed closing of a military base, and that the proposed action be delayed for a period of 120 days following such report. There was no authorization for the Committee to disapprove the base closing. Citing the administrative inefficiencies attendant to such mandatory delay, the President vetoed the bill. ${ }^{235}$ Alhough Johnson recognized the technical distinction between this reporting provision and a formal committee veto, he concluded that the difference did not diminish the infringement of executive duties:

... Attorneys General in unbroken succession since at least the time of President Wilson have advised their Chief Executives that socalled "come-into-agreement" clauses, requiring approval of executive action by legislative committees, are unconstitutional. Although Section 611 is not literally a "come-into-agreennent" clause, its limitations upon effective executive action, in the critical area of national defense, go substantially further than any bill heretofore enacted and approved by any President. ${ }^{236}$

The President indicated that he would sign a corresponding bill with a "reasonable reporting provision," as he later did. ${ }^{237}$

Thus, unlike his predecessors, President Johnson seems to have been directly concerned with the role being assumed by congressional committees even in the exercise of informal powers. Like Professor Harris, ${ }^{238}$ Johnson viewed a "no appropriation" provision as being practically equivalent to a "come into agreement" requirement in that the two devices give roles to committees which infringe upon executive responsibility. Johnson's stand on the "no appropriation" provision was

232. Id. at 1083.

233. Fisher, The Politics of Impounded Funds, 15 ADMIN. ScI. QUART. 361, 374

(1970). See text accompanying notes 239-41 infra.

234. H.R. 8439, 89th Cong., 1st Sess. (1965).

235. PUBLIC PAPERS OF THE PRESIDENTS: LYNDON B. JoHNSON, 1965, at 907.

236. Id. at 908.

237. Act of Sept. 16, 1965, Pub. L. No. 89-188, 79 Stat. 793, 818-19. Sec also Act of Aug. 1, 1964, Pub. L. No. 88-390, § 501, 78 Stat. 341, 358; Act of Sept. 16, 1965, Pub. L. No. 89-188, 79 Stat. 793, 811; Act of Sept. 12, 1966, Pub. L. No. 89-568, $§$ 613, 80 Stat. 739, 757. See 2 WeEsLy Comp. Pres. Docs. $1278-79$ (Sept. 12, 1966).

238. HARRIS, supra note 12, at 230-33. 
soon reversed, however, in a presidential about face which received little public notice. ${ }^{239}$ On April 1, 1969, the Department of Agriculture issued a press release noting the prior constitutional objections to the Rivers and Harbors Act which had led Johnson to impound funds ${ }^{240}$ rather than comply with the Act. The release quoted a memorandum from President Nixon to Secretary Hardin, dated March 27, 1969, which declared that "this Administration will interpose no objection to the procedures involved in the accomplishment of watershed projects under this Law."241

Neither President Nixon nor President Ford has substantially affected the trend toward use of the cominittee veto and the congressional resolution. For some time following his acceptance of the "no" appropriation" provision, President Nixon's position on committee control provisions was unclear. Nixon regularly signed "no appropriation" and "report and wait" provisions, and several formal cominittee veto bills received his signature without comment. ${ }^{242}$ In 1972, however, Nixon made clear that his approval of the "no appropriation" provision signified no more than a return to the position of President Eisenhower. ${ }^{243}$ Like Eisenhower, Nixon demanded a procedural limit on the extent to which Congress and its committees could interfere witl executive affairs. ${ }^{244}$ Nevertheless, during the Nixon administration, use of the formal committee veto made significant advances. Though President Ford has spoken out on a somewhat unique use of the concurrent resolution, ${ }^{245}$ he has taken a stand on neither the committee veto nor the more common uses of congressional resolutions. The use of extralegislative control devices has increased nrarkedly during the first months of the Ford administration, yet President Ford has repeatedly signed the measures without protest. ${ }^{246}$

\section{III}

\section{CONGRESS IN THE EYES OF THE FRAMERS}

As outlined in Section II, congressional creation of statutory power enabling Congress or its committees to retain jurisdiction over subjects

239. See Doane's Agricultural Reports, May 8, 1969, at 31.

240. Dep't of Agriculture, Release No. USDA 1015-69, April 1, 1969.

241. Id.

242. The provision sisnged by Mr. Nixon are included in the list of committee veto statutes at note 162 supra.

243. See the 1972 presidential comments on Public Buildings legislation cited in note 215 supra.

244. Mr. Nixon also voiced long silent presidential opposition to the use of congressional resolutions to control the executive. See note 160 supra.

245. See note 160 supra.

246. See notes 145,162 supra. 
of legislation evolved late in the history of the Republic, and was repeatedly contested by the executive branch. Initially, such power was assumed only when activities of Congress or its committees were directed to the formulation or enactment of laws. The modern practice, by contrast, is not so limited. The fact that the historical precedent for the current use of congressional extra-legislative power was strictly confined in scope and einerged only after considerable debate over congressional control of executive power, ${ }^{247}$ suggests that the present practices would have been regarded as improper by the Framers and their early successors. Likewise, no support for extra-legislative control of the executive can be derived by analogy from the non-legislative roles granted to Congress by the Constitution; ${ }^{248}$ these functions are explicitly stated, and the ways in which they may be exercised are narrowly specified. ${ }^{249}$

The purposes of the Framers themselves provide a test of constitutional validity that is more reliable than is historical precedent or analogy. This section will therefore examine the constitutional debates relating to the separation of powers provisions of the Constitution. The debates suggest that the Framers envisaged two distinct categories of restriction: (1) limitation of the individual powers of legislators; and (2) limitation of the institutional power of Congress. From these intended limitations we derive four criteria for judging the constitutionality of particular instances of extra-legislative control. In Section IV these criteria will be used to analyze the potential effects of extralegislative practices and to formulate conclusions about their constitutionality.

\section{A. Control of the Legislative Branch of Government}

The purpose of the Framers of the Constitution, who gathered in secret convention in May, 1787, was to formulate a new plan of governinent to replace the faltering Confederation. The principle was early established that the new government was to be one of independent powers rather than one with powers delegated by the sovereign states, reflecting the view that the weakness of the Confederation was its subordination of national government to the individual states. The critical focus of the Constitutional Convention then became the containment of the new federal power througl substantive and procedural limitations.

The confinement of congressional power was a fundamental part of the Framers' attempt to delimit federal authority as a whole. There

247. See generally Section II of this Comment.

248. Cooper and Cooper, for example, in defending the legislative veto draw support from the impeachment power and other special powers granted Congress by the Constitution. Cooper \& Cooper, supra note 13, at 473, 478.

249. See note 35 supra. 
was general acceptance of the notion expressed shortly before the Convention by John Adams, "that the legislative power is necessarily sovereign and supreme over the executive . . ."250 This thought was later echoed by Alexander Hamilton: "The tendency of the legislative authority to absorb every other has been fully . . . illustrated . . . . In governments purely republican, this tendency is almost irresistible."251 This tendency in mind, Madison warned: "[M]t is against the enterprising ambition of this [legislative] department that the people ought to indulge all their jealousy and exhaust all their precautions."252 Indeed, of all the problems that faced the Convention, the role and structure of the new legislature seems to have been foremost in the minds and debates of the delegates. ${ }^{253}$

Because of the Framers' strong concern for the tendency of the legislative branch to encroacl on the Executive, procedural powers assumed by Congress though not explicitly given it by the Constitution inust be critically analyzed. The separation of powers principle as formulated in the Constitution lends no easy determination of the validity of a statute granting Congress a non-legislative role. Unlike nnany state constitutions with broad negative injunctions against the mixing of governmental functions, ${ }^{254}$ the Federal Constitution is drafted largely in terms of affirmative grants of power. The respective roles of each branch have been defined in significant part by an accommodation of affirmatively granted functions resulting in "de facto" limitations on the powers of each branch. ${ }^{255}$ Therefore, even if simple labeling of a par-

250. J. ADAMS, A Defense of the Constitutions of GovernMent of the UNITED STATES of AMERICA 362 (3d ed. 1797) [hereinafter cited as ADAMS]. John Adams was in England at the time of the Convention. His book was written in response to an attack on the forms of government springing up in the American states made by Turgot. The work was published first in London, then in the United States. It was widely read by, and exerted considerable influence on the delegates to the Convention. C. Warren, The Making of the Constitution, 155-57, 815-18 (1929); 3 M. FARRAND, THE ReCORDS OF tHE FEDERAL CONVENTION of 1787, 33 (1966 ed.) [hereinafter cited as FARRAND] (letter from Benjamin Rush to Richard Price, June 2, 1787); 1 FARRAND 539.

251. The Federalist No. 71, at 433 (Mentor ed. 1961) (A. Hamilton). See also, The Federalist Nos. 48 (J. Madison), 49 (J. Madison), 73 (A. Hamilton); 2 Farrand 74.

252. The Federaisst No. 48, at 433 (J. Madison); see also 2 FarRand 74, 76.

253. See generally 1, 2 FARRAND.

254. For example, the Cahfornia Constitution provides: "The powers of state government are legislative, executive and judicial. Persons charged with the exercise of one power may not exercise either of the others except as permitted by this Constitution." CAI. CONST. art. III, $\& 3$.

255. For example, the veto clause, U.S. Const. art. I, $\S 7$, cl. 2, 3, by granting the President a portion of the legislative power, thereby limits the legislative power of Congress. That the legislative power is granted to a Congress of two Houses limits the power of each House and of both combined. A provision by which the legislature grants the executive branch enhanced power could be consistent with the Framers' purpose, 
ticular activity as executive or legislative could be achieved, this labeling would not be sufficient to determine the validity of that activity. The point at which a constitutional grant of power becomes a mandatory limitation, unalterable by statutory arrangement, may be determined only in the light of the purposes of those who drafted the Constitution. ${ }^{256}$

\section{Limitation of Individual Powers-Control of Conflict of Interest}

In a work published shortly before the Federal Convention of 1787, John Adams suggested:

If we should extend our candor so far as to own that the majority of mankind are generally under the domain of benevolence and good intentions, yet it must be confessed that a vast majority frequently transgress, and what is more decidedly in point, not only a majority but almost all, confine their benevolence to their families, relations, personal friends, parish, village, city, county, province, and that very few indeed extend it impartially to the whole community. Now, grant but this truth and the question is decided. If a majority are capable of preferring their own private interests or that of their families, counties, and party, to that of the nation collectively, some provision must be made in the Constitution in favor of justice, to compell all to represent the common right, the public good, the universal law in preference to all private and partial considerations. ${ }^{257}$

This skepticism regarding the scope of human benevolence is found throughout the debates concerning the power of Congress. In The Federalist No. 10, Madison reflected the heavy preoccupation with the problem of overbearing private interests in the legislature, and suggested the means by which the Constitution seeks to mitigate this danger:

Among the numerous advantages promised by a well constructed

while a similar statutory provision by which the legislature enhances its own power might be contrary to that purpose.

256. The separation of powers doctrine has been applied leniently by the Supremo Court in the case of delegation of congressional power to bodies outside Congress. See, e.g., K. Davis, Administrative LAW Text $\$ 1.08$ and ch. 2 (1972). This fact, however, cannot be given weight in the context of enhancement of congressional power. As will be demonstrated, the Framers' separation of the powers of government reflected their primary concern with limitation to legislative power.

257. 1 ADAMs 215-16, quoted in $1 \mathrm{~J}$. Story, Commentaries on the ConstTtution of THE UNITEd States 411-12 (5th ed. 1891) [hereinafter cited as Story]. See THE FEDERAIIST Nos. 10 (J. Madison) and 51 (A. Hamilton). On November 24, 1803 Jonathan Dayton, one of the Convention's leading advocates of state equality in the Senate, adinonished that body: "Look through that instrument from beginning to end, and you will not find an article which is not founded on the presumption of a clashing of interests." 3 FARRAND 400. 
Union, none deserves to be more accurately developed than its tendency to break and control the violence of faction.

By a faction $I$ understand a number of citizens, whether amounting to a majority or minority of the whole, who are united and actuated by some common impulse of passion, or of interest, adverse to the rights of other citizens, or to the permanent and aggregate interests of the community.

The inference to which we are brought is that the causes of faction cannot be renioved and that relief is only to be sought in the means of controlling its effects.

By what ineans is this object attainable? Evidently by one of two only. Either the existence of the same passion or interest in a majority at the same time must be prevented, or the majority, having such coexistent passion or interest, must be rendered, by their number and local situation, unable to concert and carry into effect schemes of oppression....

...

... Extend the sphere [of the society] and you take in a greater variety of parties and interests; you make it less probable that a majority of the whole will have a common motive to invade the rights of other citizens . . . . 258

Thus, Madison concluded that the legislature, the body authorized to create governmental power, is to be restricted to a large body representing a multiphicity of interests and incapable of precipitating into dominating factions. ${ }^{250}$

The Framers' concern over the conflict between public and private interests was directed at the human tendency to favor both local interest over national interest, and self-interest over the general interest. These tendencies were dealt with by assuring that representational interests would be expressed only through the institutional filter of bicameralism and by placing limitations on the powers of individual legislators.

258. The Federalist No. 10 (J. Madison). See also The Federalist Nos. 51 (J. Madison) and 60 (A. Hamilton); SToRY 415, 417. On June 4 Madison argued before the Committee of the Whole:

There is diversity of Interest in every Country the Rich \& poor, the Dr. \& Cr. the followers of different Demagogues, the diversity of religious Sects-The Effects of these parties are obvious in the ant'. Govt.- the same causes will operate with us-We must introduce Cliecks, which will destroy the measures of an interested majority-....

1 FarRand 108.

259. See further excerpt from The Federalist No. 10, text at note 291 infra. 


\section{a. Local Interests}

The Framers recognized-indeed insisted on-the legitimacy of representation of local interests in the national government. The critical issue at the Convention was how to combine these interests into an acceptable national body capable of resisting domination by any other coalition of local interests. The Framers' primary answer to this question was bicameralism. ${ }^{260}$

The bicameral principle had been incorporated into the first plan laid before the Convention. The Virginia Plan sought to institute a supreme national government to which the states would be subordinated ${ }^{261}$ and heeded Adams' warning ${ }^{262}$ by providing that "the National Legislature ought to consist of two branches." ${ }^{263}$ This resolution was accepted unanimously and without debate by the Committee of the Whole. ${ }^{264}$ Following the Committee's report, however, Mr. Patterson presented the New Jersey Plan, ${ }^{265}$ proposing that the states continue to be fundamental governmental units, and advocating retention of a more powerful version of the umicameral Congress of the Confederation. ${ }^{266}$

This fundamental difference in approach as to how to best limit federal power was debated on June 20 and $21,1787 .^{267}$ Both sides agreed that limitations were essential. The supporters of the Virginia Plan saw bicameralisin as the necessary means of achieving this limitation. ${ }^{28}$ Those who supported the New Jersey Plan, while recognizing the importance of a bicameral legislature at the state level, ${ }^{260}$ thought that retention of power in the states was a better way of limiting federal power and providing a sufficient guarantee of a controlled national government. ${ }^{270}$ Had all the Framers imitially accepted the goal of a strong

260. See note 262 infra.

261. 1 FARRAND 20, 249.

262. Adams warned: "[O]f all possible forms of government, a sovereignty in one assembly, successively chosen by the people, is, perhaps, the best calculated to facilitate the gratification of self-love and pursuit of the self interest of a few individuals." 3 Adams 284. See also 1 Adams 363; 3 Adams 283-84; 1 FarRand 101, 254, 336-44, 35458; 3 FARRAND 40, 340, 359. Story discusses the purposes of a dual legislature at some length. 1 STORY 409-421.

263. 1 FARRAND 20.

264. Id. at $48,55,60$.

265. Id. at 242 .

266. Id.

267. Id. at 336-44, 354-58.

268. See id. at 259 (Mr. Wilson).

269. Id. at 341.

270. Id. at 340-41 (statements of Mr. Martin and Mr. Sherman), 351 (statement of Mr. Patterson). Indeed, Adams recognized that his principle of legislative supremacy did not apply to the Confederation. He asserted not that the Confederation was an exception, but that the Congress thereof was not a legislative assembly at all; it was a dip- 
national government, a bicameral legislative structure would have met essentially no opposition. ${ }^{271}$ When resolution 3 of the Virginia Plan passed on June 21 by a 7 to 3 vote (with one state divided), ${ }^{272}$ the last serious challenge to the adoption of a two-branch legislative structure ended. Later this structure became the basis of the Connecticut compromise and the sine qua non of the acceptance of the new government by the small states, which earher had opposed bicameralism. ${ }^{273}$

By establishing two Houses, each with absolute power to negate legislative acts of the other, ${ }^{274}$ the Constitution contemplates a tug-ofwar with regard to local interests: neither side can win so long as it does not represent combinations of imterests identical to those represented by the other side. Thus the bicameral check requires the two houses be differently structured — be "animated by a different spirit" 275 to assure an opposition of interests and to provide an effective check on operation of the legislature. ${ }^{276}$

The Virginia Plan provided that the first branch of the legislature be elected by the people of the several states, and that the second branch be elected by the first. ${ }^{277}$ In each, the states would be represented in proportion to their free inhabitants or their quota of contribution. Because this scheme was unacceptable to the small states, which had previously enjoyed equality in Congress, the question of state representation became the critical issue of the Convention ${ }^{278}$ and the topic of its great debates. ${ }^{279}$ The sinall states feared a coincidence of interest among the large states would subject thein to oppression and threaten their existence, ${ }^{280}$ while the large states resisted a systen

lomatic assembly of representatives of the state legislatures. 1 ADAMS 362-63. See also 1 FARRAND 256.

271. See 1 StoRy 416. Among the delegates, only Dr. Franklin was reported opposed to bicameral legislative structure. 1 FARRAND 48; 3 FARRAND 297.

272. 1 FARRAND 358.

273. Id. at $355,461-62$.

274. 2 FARraND 196-97; 1 Farrand 165.

275. 3 FARRAND 419 (letter from Gouverneur Morris to Robert Walsh, Feb. 5, 1811).

276. Madison wrote:

In republican government the legislative authority necessarily predominates.

The remedy for this imconveniency is to divide the legislature into different branches; and to render them, by different modes of election and different principles of action, as little connected with eacli other as the nature of their common functions and their common dependence on the society will permit.

The Federalist No. 51. See also The Federalist No. 62 (J. Madison).

277. 1 FARRAND 20.

278. "The great difficulty lies in the affair of Representation; and if this could be adjusted, all others would be surmountable." Id. at 321 (speech of Mr. Madison).

279. See id. at 167, 176-80, 196-202, 321, 343, 355-58, 438-41, 444-50, 461-68, 55051; 2 FarRand 5-11, 13-14, 17-20, 25.

280. 1 FARRAND 177, 355, 484, 488, 491. 
wherin laws could be passed by representatives of a minority of the people.

Although the idea that states be equally represented in only the second House had been repeatedly suggested as a compromise, ${ }^{281}$ it had been either ignored or rejected. ${ }^{282}$ When the Convention had reached an impasse, however, and the matter of representation in the Senate was referred to a special committee for consideration, ${ }^{283}$ the concept was revived and was finally accepted by the Convention as the Connecticut compronnise. ${ }^{284}$ The principle that one House should represent the people, the other states, ${ }^{285}$ was so important to the Framers that they inserted a constitutional provision to ensure that such representation was not to be altered even by constitutional amendment, save with consent of the states affected. ${ }^{288}$

The Constitution specifies not only that there be two Houses of Congress; 287 it also spells out precisely how those Houses are to be structured in terms of representation. ${ }^{288}$.In contrast to the executive and the judicial branches, Congress is composed of representatives of local interests. The constitutional provisions for the terms of representation of legislators operate on the presumption that each Senator and Representative will represent his or her constituents. ${ }^{289}$ In one sense this duty to represent local constituencies is contrary to the goal of a government in which national concerns predominate. The structure in which these local representatives meet, however, provides a corrective for their parochial biases. Because each piece of legislation needs at least the majority support of each legislating body, local interests tend to cancel each other out. Thus, legislation passes through what is effectively a constitutional averaging process based on a specific, preestablished weighting system, designed to cut across potential factional interests. The dual representation base and different terms of office and qualifications together operate to effect the bicameral check on in-

281. E.g., id. at 52, 87, 201, 343, 461-62, 468.

282. Id. at 201,510 .

283. Id. at 511-16 (July 2).

284. Id. at 550-51 (July 7); 2 FARRAND 15 (July 15).

285. 1 FARRAND 461-62.

286. 2 FARRAND 631. See U.S. CoNST. art. V.

287. U.S. CONST. art. I, $\S 1$.

288. Id. §§ 2,3 .

289. See 2 FARRAND 80 (statement of Mr. Madison) (quoted in text accompanying note 324 infra). This point is illustrated by Mr. Butler's response to Mr. Randolph's advocacy of a plurality in the executive department: "a single magistrate [is] most likely to answer the purpose of the remote parts. If one man should be appointed he would be responsible to the whole, and would be impartial to its interests. If three or more slould be taken from as many districts, there would be a constant struggle for local advantages." 1 FARRAND 88-89. 
stitutional power and lessen the danger that particular interests will dominate the legislature. ${ }^{280}$

\section{b. Self-Interest}

On the one hand, the Framers recognized the necessity of having local interests represented in the government, but sought to subordinate them to the national imterest rather than eliminate them. On the other hand, they saw no value to other forms of self-interest and sought to eliminate their influence on the governmental process. Their concern focused on the legislative branch:

No man is allowed to be a judge in his own cause, because his interest would certainly bias his judgment, and, not improbably, corrupt his integrity. With equal, nay with greater reason, a body of men are unfit to be both judges and parties at the same time; yet what are many of the most important acts of legislation but so many judicial determinations, not indeed concerning the rights of single persons, but concerning the rights of large bodies of citizens? And what are the different classes of legislators but advocates and parties to the causes which they determine? . . . ${ }^{291}$

Governmental susceptibility to the influence of a self-interested legislature was minimized in part by structuring a Congress resistant to dominance by factions. In addition, however, the Framers sought to limit the opportunity for exercise of independent power by individual Congressinen. A primary concern at the Convention was that power should not be created and controlled by the same hand. ${ }^{202}$ The Constitution's treatment of the eligibility of Congressmen for public office and of congressional power to appoint public officials ${ }^{293}$ inanifests this concern. Article I section 6 of the Constitution reads in part:

No Senator or Representative shall, during the Time for which he was elected, be appointed to any Civil Office under the Authority of United States, which shall have been created or the Emoluments whereof shall have been increased during such time; and no Person holding any Office under the United States shall be a Member of either House during his Continuance in Office.

The two independent disabilities imposed by this passage were regarded differently by the Framers. The second clause, known as the incompatibility clause, forbids the simultaneous holding of a congressional seat and other federal public office. It was passed by the Con-

290. The Federalist Nos. 51, 62 (J. Madison).

291. The Federalist No. 10, at 79 (Mentor ed. 1961) (J. Madison).

292. See, e.g., 1 FARRAND 34, 139-40.

293. These provisions may in addition be taken as addressed to the previousiy discussed conflict between local and national interests, as considerations of local interest may arise from considerations of self interest. 
vention without debate. The first clause, known as the ineligibility clause, was fervently debated, its opponents feeling that it would be degrading to members of Congress, and that it would deter talented individuals from seeking election to the legislature. ${ }^{204}$ The purpose of these two clauses, however, was the same-to avoid corruption.

The predecessor of this section in the Virginia Plan would have forbidden a federal legislator to serve simultaneously in other federal or state offices, and would have continued the inehigibility for federal office for a year beyond the expiration of the legislator's term in Congress. ${ }^{205}$ After the ban on holding of state office had been removed, ${ }^{200}$ Madison moved for a restriction close to that finally adopted; inehgibility was to be limited to offices created or to offices the emoluments of which had been augmented during a member's term of service. ${ }^{297}$ Mr. Wilson supported this motion, urging that the proper cure for the feared corruption-that the legislature would appoint resigning members to vacant offices-was to deny the legislature the proposed power to appoint officers. The other "branch of corruption," the danger that unnecessary offices would be created for hopeful Congressmen, was to be remedied by Madison's amendinent. ${ }^{208}$ For the time, however, this solution was rejected. ${ }^{209}$ In addition to the incompatibility provision, the version of the clause favored by the Comnittee of Detail stipulated that all meinbers of Congress would be ineligible during their terms of office, and specified that Senators would be ineligible for one year after completion of their terms. ${ }^{300}$ Debate on this version also pitted the argument that possibilities for corruption should be minimized against the contention that ineligibility would leave the legislature without willing talent. ${ }^{301} \mathrm{Mr}$. Gerry objected to a proposed

294. 1 FARRAND 376, 386-89; 2 FARRAND 283-89.

295. The provision read:

Resolved that the Members of the first branch of the national Legislature ought ... . to be ineligible to any office established by a particular State or under the authority of the United States (except those peculiarly belonging to the functions of the first branch) during the term of service, and under the national government for the space of one year after its expiration.

A similar provision applied to the second brancli. 1 FARRAND 228-29.

296. Id. at 386. Mr. Luther Martin explained this action to the Maryland Legislature as follows:

[N]o good reason could be assigned, wliy a senator or representative should be incapacitated to loold an office in his own government, since it can only bind him more closely to his State, and attach him the more to its interests, whicll, as its representative, he is bound to consult and sacredly guard. ... 3 FARRAND 200.

297. Madison's notion, lrowever, still required ineligibility one year after the term of office was completed as well as during the term of office. 1 FARRAND 386.

298. Id. at 387.

299. Id. at 390 .

300. 2 FARRAND 180.

301. Id. at 283-90. 
substitution of a mere mcompatibility clause on the grounds that if Senators had the power to appoint ambassadors, as was then proposed, eligibility for office immediately upon leaving Congress would lead to a proliferation of unnecessary ambassadorships. ${ }^{302}$ Debate was then postponed until the powers of the Senate had been more firmly defined, and on August 31 this and other undecided measures, including the clause concerning the appointment power, were submitted to a "Committee of Eleven," consisting of one member from each state. ${ }^{303}$ The following day the Committee recommended that a legislator be inehigible during the entire term for which he was elected, thus preventing him from resigning in order to accept other public office. ${ }^{304}$

On September 3, Mr. Pinkney, considering ineligibility degrading, ${ }^{305}$ and wishing "to restrain the proposition to a mere incompatability, ${ }^{306}$ reintroduced his earlier defeated inotion ${ }^{307}$ calling only for the automatic vacation of the seat of a meinber upon his acceptance of any other federal office for which emoluments might be received..$^{308}$ The Convention again voted to retain the more stringent ineligibility clause as well as the non-controverted incompatibility clause, but coinpromised by adopting the modification previously suggested by Madison narrowing ineligibility to offices "created or the emoluments whereof shall have been increased" during the legislator's tenure in office. $^{309}$ The final version, therefore, permitted appointment of legislators, upon vacation of their legislative office, to vacant but previously existing public office.

Throughout these debates the only significant argument advanced in favor of the clause was the danger of corruption. ${ }^{310}$ Institutional

302. Id. at 285 .

303. Id. at 481 .

304. Id. at 484 .

305. Id. at 283.

306. Id. at 490 .

307. Id. at 289.

308. Id. at 489-90. In response to an identical motion Colonel Mason had earlier "ironically proposed to strike out the whole section, as a more effectual expedient for encouraging that exotic corruption which might not otherwise thrive so well in the American Soil . ..." Id. at 284.

309. Id. at 492 . As a result of this compromise the Committee promptly recommended, and the Convention accepted, transfer of the appointment power from the Senate to the Executive. See text accompanying and following note 331 infra.

310. But see S. REP. No. 563 67th Cong., 2d Sess. (1922), quoted in 6 Cannow's Precedents of the House of Representatives $\S 64$ (1935). There the Senate Judiciary Committee discusscd the issue of eligibility with regard to the propriety of the President's appointment of two Congressmen to a newly created commission. The report stated:

There was a dual purpose in the provision under review, first, to remove the temptation from meinbers to multiply offices to which they might be appointed, either in their lonor of their profit, and, second, and perhaps more important as viewed by the fathers, to deprive the Executive, with whom was 
power was briefly considered a factor when it was argued that eligibility was necessary to lessen the influence of the Executive; ${ }^{\mathbf{3 1 1}}$ later it was argued that ineligibility was necessary for the same purpose. ${ }^{312}$

Intimately connected with the Framers' treatment of eligibility for office was their delegation of the appointment power. Madison's original suggestion that ineligibility be limited to newly created or aggrandized offices was characterized as only a partial remedy to the evil of corruption, since present officers might be translated into newly created positions, leaving vacancies to be filled by members of Congressmen. ${ }^{\mathbf{3 1 3}}$ As liad been suggested by $\mathrm{Mr}$. Wilson, ${ }^{314}$ this potential loophole was closed by denying Congress the power to appoint officers. Article II, section 2 of the Constitution provides:

[The President] shall nominate, and by and with the Advice and Consent of the Senate, shall appoint Ambassadors, other public Ministers and Consuls, Judges of the supreine Court, and all other Officers of the United States, whose Appointments are not herein otherwise provided for, and which shall be established by Law; but the Congress may by Law vest the Appointment of such inferior Officers, as they think proper, in the President alone, in the Courts of Law, or in the Heads of Departments.

While the placement of the appointment power affects institutional power among the branclies, no institutional argument compelled a particular placement of the power. As in the debates over the legislators' eligibility for office, consideration of potential conflicts of interest controlled the final decision. The Virginia Plan originally called for the appointment of judges by the legislature ${ }^{815}$ and the Committee of the Whole added a general appointment power in the Executive for officers not otherwise provided for in the Constitution. ${ }^{310}$ That sucls general appointment power should rest in the Executive seems never to have been questioned. Appointment of judges by the legislature, however, raised the objection that appointment by a large body would

to rest the power of appointment, of the opportunity to constrain Members of Congress to conform to his desires concerning legislation by holding out to them the hope of appointment to offices which they were to create or render more attractive by an increase of salary. . . . However fanciful such a danger may seem to us, it was notorious in their day that the King of Great Britain, or at least his ministers, often secured from Parliament legislation favored by thein by a liberal distribution of offices, pensions, peerages, and even of cold cash.

6 Cannon's Precedents of the House of Representatives, $\$ 64$ at 72.

311. 2 FARRAND 490 (Morris), 491 (Wilson).

312. The Federalist No. 76 (A. Hamilton).

313. 1 FARRAND 387-88.

314. Id. at 387.

315. Id. at 21 .

316. Id. at 67. 
lead to intrigue and corrupt appointments, each member hiding his selfinterest behind the actions of his colleagues. ${ }^{317}$ During debate in the Committee of the Whole, appoimtment of judges by the Executive was suggested by both Wilson ${ }^{318}$ and Hamilton, Hamilton adding that the Senate should be given power to reject the appointment. ${ }^{319}$ However, Madison's suggestion that appointment of judges be made by the smaller, more experienced Senate was accepted ${ }^{320}$ and included in the Committee's report. ${ }^{321}$

In the Convention debate on the Committee report, Mr. Ghorum argued that even the Senate was too large a body to produce responsible appoimtments, and suggested judicial appoimtments be made by the Executive with the advice and consent of the Senate, as had been the successful practice in Massachusets for 140 years. ${ }^{322}$ Mr. Madison, previously a supporter of appoimtment by the Senate, had changed his mind simce equal state representation in the Senate had been adopted, and moved to effect Mr. Ghorum's suggestion. ${ }^{323}$ Madison's arguments, noted in his journal of the Convention, reflect considerable concern for controlling self-interest and partiality.

1 that it secured the responsibility of the Executive who would in general be more capable \& likely to select fit characters than the Legislature or even the $2 \mathrm{~d}$. $b$. of it, who might hide their selfish motives under the number concerned in the appoimtment-2 that in case of any flagrant partiality or error, in the nomination, it might be fairly presumed that $\% 3$ of the $2 \mathrm{~d}$. branch would join in putting a negative on it. 3 that as the $2 \mathrm{~d}$. b. was very differently constituted when the appointment of Judges was formerly referred to it, and was now to be composed of equal votes froin all the States, the principle of compromise which had prevailed in other instances required in this that their shd. be a concurrence of two authorities, in one of which the people, in the other the states, should be represented. The Executive Magistrate wd be considered as a national officer, acting for and equally sympathizing with every part of the U. States. If the $2 d$. branch alone should have this power, the Judges might be appointed by a minority of the people, tho' by a majority, of the States, which could not be justified on any principle as their proceedings relate to the people rather than to the States . . . ..$^{324}$

The motion failed by a 6 to 3 vote, ${ }^{325}$ however, and the resolution call-

317. Id. at 119, 120; The Federalist No. 76 (A. Hamilton).

318. 1 FARRAND 119.

319. $1 d$. at 128.

320. Id. at 232-33.

321. Id. at 236-37.

322. 2 FARRAND $41,44$.

323. Id. at 44,80 .

324. Id at 80-81.

325. Id. at 83 . 
ing for appointment of judges by the Senate was referred to the Committee of Detail. ${ }^{326}$ In its report of August 6, the Committee called for Senate appointment of both judges and ambassadors, ${ }^{327}$ and the Convention thereafter added "other public ministers" to the list. ${ }^{328}$ Final action was postponed, ${ }^{829}$ and on August 31 the appoinment clause was referred to the Committee of Eleven along with the clause dealing with eligibility for office. ${ }^{830}$

On the following day the Committee recommended that legislators be inehgible for any civil office during the time for which they were elected. ${ }^{331}$ Only after the Convention had deeided the issue of ineligibility, limiting it to newly created offices or those offices the emoluments of which had been enhanced, did the Committee act on the appointment power. On September 4 the Committee report adopted the earlier suggestions of Hamilton, Ghorum, and Madison. ${ }^{332}$ Though placement of the appointment power in the Senate had previously survived every challenge, the Convention now accepted transfer of that power to the Executive virtually without debate. Indeed, it was now objected that the Senate, which retained the power to disapprove the President's nominations, should have no role in the appointment of officers. ${ }^{\text {333 }}$

The Convention's actions on the appointment power and eligibility for public office were intimately connected. The compromise allowing a Congressman to leave his seat and assume public office required both a corresponding abolition of the power of Congress to make appointinents, and an assurance that a Congressman would be ineligible for an office which lie had helped create. By means of these coupled provisions, the Framers assured that individuals could neither appoint themselves to positions of power, nor create such positions and immediately accept appointment to them.

In sharp contrast to the lengthy debates on the intricate connection between the appointment power and the eligibility of Congressmen for public office upon leaving Congress, stands the Convention's unquestioning acceptance of the principle that no person should simultaneously have the power to make laws as a legislator and execute them as holder of additional public office. The meaning of the Framer's silence on this matter, which was so basic as to be undeserving of debate,

326. Id. at 132.

327. Id. at 183.

328. Id. at 394.

329. Id.

330. Id. at 481. See text accompanying note 303 supra.

331. 2 FARRAND 484. See text accompanying note 304 supra.

332. 2 FARRAND 498-99.

333. Id. at 538-39. 
is necessarily a subject of speculation. Nevertheless, there seems no doubt that the bases of the restriction were the dangers of self-serving exercise of governmental power and unsymmetrical representation of local interests. ${ }^{334}$ With no countervailing objection that incompatibility, as distinguished from ineligibility, was "degrading," these dangers left no room for debate.

The Framers' overriding concern for limiting conflicts between the national interest and local and personal interests requires that these conflicts be addressed on a constitutional level. The Constitution carefully structures a group of individuals-each responsible to a local electorate-into a national body, and relegates strictly local legislation to the states. It requires two independent combinations of local interest, the two Houses of Congress, to effect a legislative act. Only in narrowly defined instances are the individual Houses authorized to step out of the Congressional structure and act outside the constitutionally defined "averaging process." This splitting of Congress into two Houses of differing structure, the incompatibility of congressional and other federal public office, the ineligibility of Congressmen for office created or rendered more lucrative by their own hand, and the denial to Congress of the power to name public officers were intended to prevent opportunities for self-serving acts. The interrelationship between the debates on the ineligibility and incompatibility clauses and the appointment power illustrates with particular clarity the intent of the Framers to sever the hand wielding power from the body creating it. This purpose, repeatedly manifest, suggests the possibility of establishing a constitutional test with which to evaluate authorizations of extra-legislative activities which inay evade the procedural safeguards limiting assertion of personal and local interests. Sucli a test, based on avoidance of conflict of interest in government, will be elaborated later in this section. ${ }^{335}$

\section{Limitation of the Institutional Power of Congress-Control of Fed- eral Power}

The goal of limiting potential conflicts of interest within Congress is an integral part of a broader purpose to limit the power of Congress and thereby check the power of federal government. The procedural checks designed to restram the influence of selfisl and parochial inter-

334. This latter speculation is supported by Mr. Luther Martin's explanation to the Maryland legislature of the reason for dropping an additional ineligibility for loolding simultaneous state office. Mr. Martin contended that there was no need for such exclusion, for holding of simultaneous state office would only bind a Congressman closer to the interests which lie is bound to represent. See note 296 supra.

335. See subection $B$ of this section, infra. 
ests are also intended to limit congressional power by disabling factions and by removing imcentives for overreaching. These limitations on the power of Congress are a final expression of the Framers' desire to limit the scope of the new federal government. Yet the attempt to limit congressional and federal power was not confined to restricting the authority of individual members of Congress. The Framers were concerned that the legislative branch, even when acting pursuant to its own view of the national interest, would assume too inuch power relative to the coordinate branches. From the outset the Convention sought to stem this asserted tendency by, in effect, granting a portion of the lawmaking power to the coordinate branches of government. ${ }^{336}$

The bicameral system, deemed essential to the control of federal power once the principle of a strong federal government had been accepted, was one of the two major checks on the institutional power of Congress. The other was the veto power. The Virginia Plan proposed that the Executive and a "convenient number of the National Judiciary" form a "council of revision" with power to examine and negate all acts of the National Legislature. ${ }^{337}$ Any such reversal would require repassage by a then unstated portion of each branch of the legislature before the vetoed act could become effective. ${ }^{388}$ The proposal was vigorously debated in the Committee of the Whole on June 4 and $6,{ }^{330}$ the principal points of contention being whether the judiciary should be included in this function, and whether a veto should be absolute or subject to override by an increased majority.

Mr. Gerry and Mr. King objected to the inclusion of the judiciary in the lawmaking process, contending that judicial power to expound the laws and rule on their constitutionality constituted a sufficient barrier against encroachment on the judicial branch, and that laws should only be reviewed by judges who had not participated in their forma-

336. The veto clause as finally enacted in essence makes the President a third participant in the legislative process, along with the two Houses of Congress, and specifies two alternative means by which a legislative act may be passed: simple passage by the "three participants," or passage by a two-thirds majority of the House and Senate following rejection by the "third participant." The legislative function of the President is quite distinct from his ordinary executive function. It is interesting to note that the Constitution authorizes a second legislative role for the Executive-that of proposing legislation to Congress. U.S. CoNST. art. $2, \S 3$.

The debates which culminated in the exclusion of the judiciary from the "revisionary power" indicate the clear design of the Framers that the judiciary should act as a check on the power of Congress to enact laws contrary to the Constitution. See note 337 and subsequent text infra.

337. 1 FARRAND 21. The term "revisionary power" vas used by the Framers to denote the power to reject acts of Congress. This power now resides in the veto clause.

338. Id.

339. Id. at 97-104, 138-40. 
tion. ${ }^{840}$ In response Wilson and Madison contended that a single executive would not have the power or prestige to confront the legislative branch alone ${ }^{341}$ and that the added support of the judiciary would be required to render the veto power an effective check on the legislature. Madison further argued that the Executive in a republican government possessed neither the emoluments nor the hereditary inagistrate's permanent stake in the public interest necessary to "place him out of the reach of foreign corruption." ${ }^{342}$ Thus Executive exercise of the veto power would need to be both controlled and supported by an association of judges. ${ }^{343}$ However, the view which prevailed ${ }^{344}$ by an 8 to 3 vote, was that the veto power should be exercised by a single Executive in order to assure impartiality and responsibility. ${ }^{345}$

The effect of the Executive veto was debated with equal vigor. Wilson and Hamilton called for institution of an absolute veto, without which the legislature could "sink [the Executive] into nonexistence."348 Madison suggested that such absolute power would be no more effective than the requirement of an increased majority for repassage, because the President would be unable to withstand legislative pressure without some support from within that body. ${ }^{347}$ Madison added that absolute Executive power was "obnoxious to the temper of this country." "848 An absolute veto was characterized as tantamount to anarchy, and dangerously subject to abuse by the Executive. ${ }^{349}$ Mr. Butler warned that " $\mathrm{m}$ all countries the Executive power is in a constant course of increase,"350 and that "a Cataline or a Croinwell"351 could arise here as elsewhere. Mr. Bedford took the extreme position and opposed all revisionary checks on the legislature, arguing that the Constitution should set boundaries and that the "Representatives of the people" should be judges of what was for their interest since the two legislative branches would constitute sufficient internal control. ${ }^{352}$ The Committee unanimously rejected the absolute Executive veto power, ${ }^{353}$

\footnotetext{
340. Id. at 97-98.

341. Id. at 138 .

342. Id.

343. Id.

344. Id. at 140.

345. Id. at $139-40$.

346. Id. at 98.

347. Id. at 99-100.

348. Id. at 100 .

349. Id. at 99-103.

350. Id. at 100 .

351. Id.

352. Id. at 100-01.

353. Id. at 103.
} 
and required a legislative majority of two-thirds for repassage of a vetoed bill. . $^{354}$

On July 21 the Convention again considered the joint exercise of the revisionary power by the Executive and the judiciary. ${ }^{355}$ Madison repeated his argument that such association was necessary to balance the power of the legislature, and that such blending of departments was necessary to assure the separation of powers. ${ }^{356}$ Colonel Mason contended that defense of the Executive was not the sole object of the revisionary power; it was also necessary to restrain "unjust and oppressive laws" which might be passed by Congress. Under the power of judicial review, judges could void such laws only if they were unconstitutional. By having a part im the revisionary power, judges would also have a chance to defeat the "unjust, oppressive or pernicious" laws which were not plainly unconstitutional. ${ }^{357}$ Though the nargin was narrower, ${ }^{358}$ the prevailing view once again was that the revisionary power was primarily to protect the Executive against legislative encroachment, ${ }^{359}$ that such power should be in the Executive alone, that expositors of the law should be separated from the making of the law, and that judges should approach the law untainted by having a part in its making. ${ }^{360}$

The Committee of Detail reported out a provision which would subject every bill to an approval requirement equivalent to that ultimately adopted. ${ }^{361}$ During the final important debate on this

354. Id. at 104.

355. 2 FARRAND 73-80.

356. Id. at $74,77$.

357. Id. at 78.

358. The vote was 4 to 3 against joining the judiciary in the "revisionary power," with two states divided. Id. at 80 .

359. Id. at 74-75.

360. Id. at 73-80.

361. Every bill, which shall have passed the House of Representatives and the Senate, shall, before it become a law, be presented to the President of the Umited States for his revision: if, upon such revision, he approve of it, he shall signify his approbation by signing it: But if, upon such revision, it shall appear to him improper for being passed into a law, he shall return it, together with his objections against it, to that House in which it shall have originated, who shall enter the objections at large on their journal and proceed to reconsider the bill. But if after such reconsideration, two thirds of that House shall, notwithstanding the objections of the President, agree to pass it, it shall together with his objections, be sent to the other House, by which it shall likewise be reconsidered, and[,] if approved by two thirds of the other House also, it shall become a law. But in all such cases, the votes of both Houses shall be determined by yeas and nays; and the names of the persons voting for or against the bill shall be entered on the journal of each House respectively. If any bill shall not be returned by the President within seven days after it shall have been presented to him, it shall be a law, unless the legislature by their adjournment, prevent its return; in which case it shall not be a law.

Id. at 181 . 
clause, ${ }^{302}$ however, Madison expressed concern that the provision formulated by the Committee could easily be evaded by the expedient of calling the act a "resolution" or "vote" rather than "bill." M63 Madison proposed language to avoid this possibility, but "after a short and rather confused conversation on the subject, the suggestion was put $\&$ rejected ...." "364 The following day Randolph cast Madison's proposal in the present language of the Constitution, and the motion was accepted without debate by a 9 to 1 vote $^{365}$ (one state abstaining). This addition to the veto clause, designed to assure that all congressional actions come before the President, states:

Every Order, Resolution, or Vote to which the Concurrence of the Senate and House of Representatives may be necessary (except on a question of Adjournment) shall be presented to the President of the United States; and before the Same shall take Effect (shall be approved by him, or being disapproved by him, shall be repassed by two

362. On August 15, 1787, during this final debate, Madison once again raised the question of judicial participation in the revisionary power, proposing that a majority of three-fourths should be required for repassage of a bill disapproved by the two coordinate departments. In support of Madison, Mr. Mercer suggested that precautions should be taken in the passage of laws, but that to preserve the independence of the departments such laws should be "uncontrollable" once enacted. Consequently, the judiciary should be able to participate in the revisionary power, but should have no power to declare laws void. This, it was impled, would avoid the conflict which would be present should a judge be forced to decide the constitutionality of a law he had helped to create. Nevertheless, the motion failed once again. 2 FarRaND 298. At the conclusion of the ensuing discussion of the inadequacy of the revisionary power as a check on Congress, a compromise measure declared that a majority of three-fourths would be required to override a presidential veto. Id. at 301 .

At the time of this debate, and each of the other debates in which participation of the judiciary in the revisionary power was proposed, the presumed rule was that the President was to be elected by the legislature. See 1 FARRAND 21, 81, 230; 2 FarRand 32,185 . Election of the President by popular vote, by popularly chosen electors, or otherwise independently of Congress had been repeatedly rejected. See 1 FarRand 81, 176; 2 FarRaNd 32, 118-21, 402. On September 4, however, the Committee of Eleven, in order to make members of Congress eligible for the Presidency, proposed removal of the election of the President from Congress. 2 FArRaND 497, 499. See id. at 521. Thereafter, the single attempt to restore the election to Congress was rejected. Id. at 511. It was on this note that Mr. Williamson, who had proposed the comproinise compelling a vote of three-fourths of the members of each House in order to override the President, became convinced that this requirement put too much power in the hands of the President. He proposed a return to the rule that a two-third vote be required to override. Id. at 585. It was argued that the three-fourths vote requirements would allow only a few Senators hopeful of presidential nomination to offices to join the President in preventing passage of proper laws, and that a two-thirds majority requirement would be sufficient to accomplish the primary object of the revisionary power-to defend the executive department. Id. at 586. Madison, pointing out the change in elective procedure, still feared the weakness in the two-thirds figure more than the strength of threefourths. By a vote of 6 to 4 (one abstention), the two-thirds requirement was readopted.

363. Id. at 301 .

364. Id. at 302 .

365. Id. at 304-05. 
thirds of the Senate and House of Representatives, according to the Rules and Limitations prescribed in the Case of a Bill. ${ }^{306}$

From this history it may be concluded that the primary objective of the veto power is to curb legislative authority by shielding the Executive from encroachment by the legislature. The judiciary was excluded from the exercise of this veto power in contemplation that it would provide an additional check on congressional power through independent review of laws without taint of prior involvement. The President's veto power was limited by allowing two-thirds of the membership of each House to override the veto, not because the veto clause in that form was thought to be a sufficient check on the legislature, but because of the appearance of monarchy, and the feared abuses by the Executive. Although the Framers took steps to prevent evasion of the veto power by changes of label, ${ }^{367}$ they do not appear to have considered the possibility that congressional action falling outside the language of the veto clause might be authorized by statute, rather than by the Constitution.

\section{B. Four Criteria}

From the foregoing analysis of the constitutional debates and contemporary writings emerge four criteria by which it is possible to judge the constitutional validity of extra-legislative control devices. These criteria reflect the factors which the Framers deemed important in formulating a structure for federal government. While not entirely imdependent of one another, they express the purposes of the Framers and thereby explain the limitations imposed by the Constitution.

In analyzing the constitutionality of a particular grant or reservation of power it is relevant to ask, first, whether the measure under examination forces legislators to choose between their constituency and the national interest. The Constitution's balancing of two modes of state representation to avoid regional dominance of the national legislature, and the Framers' lengthy debates concerming the problems of locally oriented factions, indicate the constitutional significance of this consideration. Second, it is important to know whether the measure encourages the exercise of self-interest independent of any preexisting or coexisting local orientation of the power wielding body. The Framers expressed concern for the human tendency to seek wealth and power from political office, and they strove to insulate public offices from this aspect of human natures. Third, it needs to be ascertained whether the statute tends toward legislative dominance of the government, thus upsetting the power balance intended by the

366. U.S. CoNST. art. I, § 7, cl. 3 .

367. See text at note 363 supra. 
Framers. The final inquiry comprehends the first three: does the statute foster increase of overall federal power? This criterion encapsulates the overriding concern of the Framers for control of federal power. This concern found its culmination in the procedural checks through which the departments were given, even at the cost of governmental efficiency, overlapping dependent powers so that no one branch could operate without a retarding frictional force from the others.

These criteria, which express the attitude of the Framers with regard to the proper role of Congress, are relevant to evaluation of the constitutionality of modern extra-legislative control statutes. These purposes of the Framers were not matters dealt with only peripherally in drafting the Constitution-matters which must be vaguely devined through reference to practice of the times or to multistep theories of uncertain applicability-they were concerns central to the constitutional debates, and which could hardly have been more clearly stated, nor more repeatedly verified.

\section{IV}

\section{The Constitutionality of Non-Legislating CONGRESSIONAL ACTION}

The customary approach to examining the constitutional validity of statutes authorizing extra-legislative congressional activity has been to classify the authorized activity, without apparent analysis, as "executive in nature," as "legislative in nature," or as "neither of these." Authors who conclude that the activity is neither executive nor legislative characterize the authorized resolution or committee vote as a "mere event" which happens to have governmental consequences. It is therefore concluded that the authorizing statute is valid. The "executive" or "legislative" labels are generally taken to imply that the statute is invalid as the denominated activities are to be carried out in a manner not authorized by the Constitution. ${ }^{368}$ This approach, however, reduces constitutional analysis to the application of a conclusory labela label unjustified by any clear definition of the underlying categories. ${ }^{\mathbf{3 6 9}}$

A inore satisfactory analysis of extra-legislative control statutes requires examining the impacts of such statutes on governmental power and its distribution in the hight of the purposes of the Framers. As shown in Section III, the Framers took great care to establish procedures limiting aggrandizement of the power of Congress as a whole or

368. See text accompanying note 142 supra, and presidential messages note 9 , supra.

369. See text accompanying note 24 supra. 
that of individual legislators. The four constitutional criteria derived from this concern are statements of this necessity to circumscribe power. The impacts of extra-legislative control statutes upon congressional and governmental power must be measured against the standard provided by these criteria. This requires a two-step analysis. First it is necessary to determine whether a statute has an effect, real or potential, on the power of Congress or of individual members of Congress; then the statute's validity may be evaluated by examining that effect in the light of the four criteria.

A particular statute has an "impacl"370 on governmental power if the procedure employed allows achievement of results not attainable by standard legislative techniques. If a given procedure has no impact on congressional power-that is, if the same functional results might be achieved strictly by legislation-then the fact that the procedure is not explicitly banned by the Constitution and that no constitutional principle is violated would seem to justify leaving the decision whether the procedure should be used to the discretion of Congress. But an examination for impact upon congressional power cannot stop with examination of a procedure as employed in a particular statute at a specific point in time. Impact upon power, though important, may be subtle, or may become apparent only with passage of time. In erecting procedural barriers to exercise of power the Framers intended to limit the possibility of future abuses, not merely to provide a means of combating such abuses when found. Thus, in addition to determining the present observable effect of a statute, its potential effect on congressional power must be predicted. Furthermore, this prediction cannot be limited to the impact of the statute at issue. For a procedure to be validated as used in one context, the impact of its use in other contexts which are not differentiated by any clear, logical separation from the use in question must be considered. If these examinations reveal no impact on congressional or governmental power, then the inquiry is at an end and employment of the device under consideration should be deemed within the discretion of Congress.

If, on the other hand, some impact on congressional power is anticipated from use of an extra-legislative procedure, there remains the task of determining whether the expected impact is impermissible in light of the four criteria developed above. Where the impact infringes on one or more of the criteria, the question arises how great an infringement is to be tolerated before the statute is rendered invalid. As is true when evaluating the existence of impact, determination that

370. We shall reserve the term "impact" to designate the effect of altering congressional powers, whether or not this effect is determined to be invalid under the four criteria developed in Section III. 
infringement of the criteria in a particular instance is minor should not conclude the inquiry.

Validation of a procedural device in one context amounts to simultaneous validation of the same procedure in related contexts. Thus the danger inherent in an extra-legislative procedure lies not only in its effect in one instance but in its potential effect in related uses, and, mdeed, in its potential cumulative effect in all related uses not separated from that under consideration by some "natural" boundary. ${ }^{371}$ Thus the effect which must ultimately be subject to scrutiny under the criteria is the cumulative effect of all uses of the procedure which would be implicitly validated by validation of the use under consideration. If an infringement of the criteria is seen in this extended sense, the statute should be held invalid.

In order to analyze particular classes of extra-legislative control statutes, it is useful to categorize the various impacts they might be expected to have. Two major types of potential impact may result: (1) Congress may empower itself to act in situations where it would otherwise be powerless; and (2) by authorizing action by a simgle House or by small groups of Senators or Representatives, Congress may avoid the "constitutional averaging process" 372 to whicl all acts of legislation are subject.

371. Altlough this "slippery slope" approach may be of questionable validity in general, it seems appropriate liere. In the case of substantive limitations on the powers of Congress, each statute may be judged on its own terms. Thus, if Congress infringes upon a protected right, a court may balance this encroachment against governmental interest in it and so reach a conclusion on validity. That a particular infringement may be found valid does not restrict the court when later infringements reach unconstitutional proportions. The situation is different in the case of a procedural limitation, for the effect of a particular procedure on power is likely to be cumulative. Thus, if a procedure is held valid in one instance because it has insignificant effect, then it may be difficult to declare invalid any particular use of the device, though the cumulative effect of such statutes may, for example, result in congressional dominance of the executive.

While a procedure not explicitly banned by the Constitution can be judged only by its effect, it is the procedure, not the effect which is in question. This observation may argue for a blanket declaration that a particular procedure, say action by concurrent resolution, is either valid or invalid. This approach, however, is unnecessary. A given use of a particular procedure must be considered invalid if a holding of validity would create potential for significant infringement of the constitutional criteria. Such potential may exist whenever no clearly defined limit on the use of the procedure can be established if allowed in the particular instance. As will be shown below, however, it is possible, that there exist isolated contexts in which a procedure, invalid in other contexts, is constitutionally liarmless or perlaps even furthers constitutional principles. See discussion of the War Powers Resolution, text accompanying notes 474-75 infra. Absent a clear mandate to summarily consider only the validity of a procedure, this Comment will consider both procedures and the context of their use. Thus consideration will be given to classes of statutes which arguably are isolated by principled bounds from other applications of the same procedure.

372. See text accompanying notes $287-90$ supra. 
The first category of impact may be further divided into two subcategories suggested by the purposes for which the control statutes are enacted. First, Congress may endeavor to preserve power it has mustered at a particular instant in time. Thus, during a period of high emotion or strong one-party dominance, Congress may authorize action by concurrent resolution and marshal a two-thirds vote to override a presidential veto, thereby preserving the momentary power for a later time. The concurrent resolution provision allows a majority to act at a later time without regard for the possibility of presidential disapproval where it would normally again need a two-thirds vote. It is also possible that a weak congressional majority, supported by a President, could preserve its power against the veto of a later Chief Executive. An identifying characteristic of this preservative impact, then, will be a tendency of the authorizing statute to reduce presidential control over congressional action below the level provided by the veto power.

While an intent to preserve congressional power with respect to the President may be discerned in a number of control statutes, ${ }^{378}$ a second purpose, corresponding to the second subcategory of impact, seems to dominate present usage. By retaining jurisdiction over a subject of legislation through an extra-legislative procedure, Congress may create for itself a discretionary power which allows it to make judgments in specific fact situations. The impact of this discretionary power arises from the resulting ability of Congress to create power in the executive without the necessity of specifying standards or guidelines for executive action.

These three classes of impact-preservation of power, creation of discretionary power, and avoidance of "constitutional averaging"-are general conceptualizations of impact which facilitate examination under the four criteria developed above. They clo not of themselves necessarily imply conclusions as to constitutionality in the absence of violation of the criteria. At each step of the analysis the ultimate concern is the underlying practical effect on power-whether the statute has the effect of fostering legislative dominance of government, of increasing general governmental power, or of fostering action serving local or personal interests. These undesirable effects, corresponding to the four criteria, will ultimately determine the statufe's constitutionality, notwithstanding the imitial characterization of its impact upon power.

Although conclusions about the constitutionality of extra-legislative activity ultimately rest on the historically derived criteria, past presidential condemnations of such activity have been based on specific

373. E.g., The War Powers Resolution, Pub. L. No. 93-148, 87 Stat. 555 (1974); see also the statutes providing for their own termination by concurrent resolution included in Appendix A. 
criticisms corresponding to two of the aforementioned categories of impact. The objection that Congress' exercise of extra-legislative control infringes on the Executive's power to execute the laws ${ }^{374}$ will be most forceful where Congress has granted itself discretionary power to fill in the details of a legislative scheme. This is a function which, whether or not it be termed "executing the laws," has customarily been performed by the executive branch. On the other hand, the contention that a measure constitutes an invalid attempt by Congress to legislate free of the veto power ${ }^{375}$ is inost persuasive where Congress seeks to preserve a present power, that present power being the standard legislative power.

In cases where examination under the four criteria reveals an illicit effect on power as viewed under the discretionary or preservative conceptualizations of impact, this correspondence between presidential criticism of extra-legislative activity based on specific constitutional provisions and these two impacts will permit the ensuing conclusion of imvalidity to be phrased in conventional constitutional terms, and will guide utilization of supporting judicial authority. The third category of impact-avoidance of the normal mode of operation of Congresscorresponds to no specific constitutional objection raised by protesting Presidents. It does, however, correspond closely to the local-and selfinterest criteria, and thus lends itself to relatively simple evaluation.

\section{A. The Constitutionality of Statutes Delegating Power of Governmental Control to Congressional Committees}

\section{Formal Committee Power-The Committee Veto}

Despite presidential opposition, Congress has increasingly bestowed formal statutory powers on its committees. In primciple a cominittee could be given statutory power to act independently, but the device mvariably used is the "committee veto," whereby a power is created in the executive branch with the proviso that an administrator gain the approval of one or more committees before that power is exercised.

Under the analysis suggested by this Comment, the committee veto presents the clearest case of a device which is constitutionally invalid..$^{376}$

374. See presidential messages, note 9 supra.

375. Id.

376. Two court of appeals cases considering informal congressional pressure on administrators have concluded that such pressure should not be allowed to influence adininistrative decisions. D.C. Federation of Civic Associations v. Volpe, 456 F.2d 1231 (D.C. Cir. 1972); Pillsbury Co. v. FTC, 354 F.2d 952 (5th Cir. 1966), discussed at note 411 infra. There is no judicial authority under the Constitution dealing directly with the committee veto. But see Springer v. Philippine Islands, 277 U.S. 189 (1928), discussed in text accoinpanying notes 397-401. 
The potential impacts of the procedure are such that it must be considered invalid per se, without respect to its particular use. ${ }^{377}$ The committce veto places final control over governmental actions in the hands of a few imdividuals answerable only to local electorates. The most characteristic impact of the device is therefore avoidance of the "constitutional averaging" required by the Framers to balance the effects of the dual role given Congressmen. Thus, authorization of a committee veto creates a conflict of interest in which an imdividual committee member inust choose between local and national interests, and breaches the first of the constitutional criteria. ${ }^{378}$ The problem is exacerbated by the fact that districts with particular interests in the subject of a committee's expertise and responsibility are heavily represented on the committee: an agricultural committee, for imstance, will be dominated by members froin agricultural states. Such self-selecting system almost guarantees that where a committee veto statute deals with expenditure of funds for local projects, several members of the relevant committee will find themselves directly involved in conflicts of interest. ${ }^{379}$ Potential conflict of interest may be more evident where a committee must make decisions with regard to local spending than where the decision has fewer or less obvious local consequences, such as where it involves foreign policy. However, conflicts may arise in any context and may be difficult to identify in advance, ${ }^{880}$ so that the potential for infringement of the local interest criterion alone justifies a per se determination that the committee veto is invalid.

The Committee veto has additional constitutional infirmities, however. It gives a committee an ongoing role in governmental

377. Compare the discussion of congressional resolutions, in subsection B. That subsection concludes that the validity of devices employing resolutions turns upon the context of their use.

378. Of course, the executive may also act with local bias when given final authority in governmental decisions. The President, however, must answer to the national electorate, and in principle is responsive to that interest. That the systcm set up by the Constitution is imperfect was recognized by the Framers. See, e.g., The Federalist No. 10. These imperfections provide no justification to disregard constitutional limitations altogether. The Constitution presumes that the Executive will act in the national interest and that the legislator may not. See notes 289 and 296.

379. That the effect of local interest is an important factor in the utilization of the committee veto is suggested by the teudency of the provisions to be restricted to control of public building and waterworks projects. See HaRRus, sulpra note 12, at 223, 226-30. The "no appropriation" restrictions in the Public Building Act of 1959, later changed to committee veto restriction, are accompanied within the statute by an explanation that their purpose is to vest final control over the location of public buildings in congressional committtees rather than in the Executive, or apparently even in Congress itself. Public Building Act of 1959, Pub. L. No. 86-249, \& 7, 73 Stat. 480. See text accompanying notes 212-15 supra.

380. For example, decisions affecting foreign policy or defense posture inay affect trade in locally produced weaponry or other wares. Such decisions could also affect the population of local military bases, with a consequent effect ou local economies. 
decisionmaking after the normal processes of lawmaking have been completed. This may be characterized as the vesting of "discretionary power" in members of the chosen committees. ${ }^{381}$ Congressional possession and exercise of such discretionary power may be seen to contravene several of the constitutional criteria.

First, the exercise by a committee of this post-legislative, discretionary power fosters both legislative dominance and expansion of governmental power in violation of two of the constitutional criteria. In the traditional scheme of enacting and enforcing laws, Congress passes legislation that simultaneously empowers and sets standards for executive action. Since the days of Jefferson and the antifederalists this specification of standards has been Congress' primary check on executive power. ${ }^{382}$ It has traditionally been the role of the executive to fill in legislative interstices through exercise of discretion where Congress has seen fit to leave flexible statutory standards. If Congress stipulates that the President may exercise his discretion only at the pleasure of its committees, these committees take over, in effect, a function traditionally exercised by the executive branch. This replacement of executive exercise of discretion by committee exercise of discretion has the potential for increasing the role of legislators at the expense of the executive, thus fostering legislative dominance.

The power of the President relative to that of Congress is roughly proportional to the amount of discretion allowed him in the execution of the laws. Generally, the more broadly a statute is drawn, the inore power the President will have relative to Congress. Thus interbranch jealousy typically prompts Congress to prepare specific and narrowly drawn legislation to limit the powers it creates. ${ }^{383}$ If Congress may retain jurisdiction over the power it creates, its primary imcentive to limit that power is no longer present; the element of balance between the branches of government is gone. Thus, delegation of supervisory power over the executive to congressional committees allows Congress a freer hand in creating federal power. Congress need not restrict the President by drafting a provision for every contingency it might consider important, but it may legislate with a broad brush. This freedoin

381. For a discussion of the creation of discretionary power as one class of impact related to extra-legislative activity see text following note $\mathbf{3 7 3}$ supra. Another category of impact, preservation of power, is less appropriate for characterizing the effect of a committee veto; it is difficult to identify a single instance where the device has been enacted in anticipation of a decline in congressional power.

382. See text accompanying note 39 supra. The enforcement of statutory standards is a check ordinarily left to the judiciary. The possible effect of congressional post-legislative power on this judicial check is discussed in connection with congressional resolutions. See text accompanying note 458 infra.

383. See Cooper \& Cooper, supra note 13, at 513. 
is indeed a motivating force in Congress' efforts to provide for extralegislative committee control, and is cited as justification therefor. ${ }^{384}$ In light of the fact that one of the Framers' principal goals in defining Congress' role was to limit federal powers, ${ }^{386}$ these efforts must be viewed critically. Creation of discretionary power in committees seems to violate the constitutional criterion imvalidating procedures which derogate limitations on federal power.

Finally, congressional creation of discretionary power which is to be exercised by Congress itself or entrusted to a congressional committee represents the creation and exercise of power by the same hand. Where the effectiveness of discretionary power is maximized by delegating the authority to a group of manageable size, a committee or even an individual, the danger of self-interest is also maximized. ${ }^{380}$ This potentiality is not lessened by the fact that the power-creating body is the entire Congress, while the power-exercising group is but a small subdivision of that body. While the individual or group wielding the power may therefore play a negligible part in its creation, a mechamism is available permitting the division and distribution of power in such a way as to satisfy every such nember or group. ${ }^{387}$ It becomes possible for Congress to precipitate into factions, ${ }^{388}$ each faction with power in its area of interest. While Congress may be expected to keep jealous watch over power delegated to an outside body, such as an administrative agency, it is more likely to acquiesce in the action of an internal distributee of power.

The committee veto, then, may be viewed as a mechamism both for avoiding "constitutional averaging" and for placing a discretionary power in the Congress. Each of these impacts on congressional power results in violation of the constitutional principles expressed by the four criteria. The extent of violation in a particular instance is generally not amenable to determination, but the effect of individual committee veto statutes on governmental roles will be cumulative. Because a means of confining the committee veto has neither been suggested nor

384. See id. at $467,513-14$.

385. See Section III.A.2. supra.

386. The self interest referred to here is that which might arise from the creation and exercise of power by the same group, without reference to the structure of that group. Although the problems are related, the self interest involved here is distinct from the earlier discussed issue of local interest resulting from the composition of the committee.

387. A useful analogy is provided by the fiduciary standard applied to corporate directors when self dealing is involved. The board is not allowed to split up into subgroups to achieve results which would not be permissible for the entire board. See Stoiber v. Miller Brewing Co., 257 Wis. 13, 42 N.W.2d 144 (1950).

388. See THE FEDERALIST No. 10 (J. Madison) quoted in text at note 258 supra. 
perceived, the analysis favored by this Comment deems the device unconstitutional.

This conclusion may be supported by more conventional textual analysis based on specific provisions of the Constitution-the appointment $^{389}$ and incompatability ${ }^{300}$ clauses. Members of a committee named in a committee veto statute exercise a discretionary power to control the course of governmental activities. Before introduction of the committee veto, exercise of this power which was not directed at enactment of legislation, would have been the function of "Officers of the United States." It is therefore arguable that a committee veto statute names members of Congress to serve as officers of the United States in violation of the appointment clause. Furthermore, since the member is designated not by name but by congressional position, it is inevitable that the member serves as "officer" concurrently with his tenure in Congress, thus violating the incompatability clause. The rejection of a labeling approach to evaluating the constitutionality of these measures, however, assumed that the exercise of powers which may be characterized as officer-like does not alone justify the conclusion that a Congressman has become an officer. The determination that exercise of power under a committee veto authorization violates the principles behind these two clauses ${ }^{391}$ suggests a closer examination of the committee veto under related authority.

Mechem defined a public office as "the right, authority, and duty, created and conferred by law, by which for a given period, either fixed by law or enduring at the pleasure of the creating power, an individual is invested with some portion of the sovereign functions of the government, to be exercised by him for the benefit of the public." ${ }^{322}$ He later added: "The nrost important characteristic [is] . . . that some portion of the sovereignty of the country, either legislative, executive, or judicial, attaches, for the time being, to be exercised for the public benefit." ${ }^{393}$ The function of a committee member under a committee veto statute fits within this definition. The committee enjoys a power created by law at the sufferance of the creating power. At any time Congress may repeal the delegated power or alter the committee's membership. The committee has sole power to authorize or forbid specified

389. U.S. CoNST. art. II, \& 2, cl. 2.

390. Id. art. I, $\$ 6$, cl. 2.

391. See text following note 294 supra.

392. F. Mecham, Public Offices and Public Officers $\$ 1$ (1890).

393. Id. at $\S 4$.

Mecham's definition was accepted by the House Judiciary Committee as governing the activities of Congressmen with respect to the incompatibility clause in its 1899 report dealing with the propriety of Congressinen accepting memberships on commissions. 
government actions. Unlike the farmers in Currin v. Wallace, ${ }^{304}$ who were allowed to vote on a program for their own benefit, the committee theoretically acts for the public benefit. ${ }^{395}$ Because members of a committee who exercise a post-legislative discretionary power are officers within Mechem's definition, a statute which designates particular Congressmen to exercise these powers runs afoul of the appointment clause, which demies the legislative branch the right to appoimt officers. ${ }^{396}$

In Springer v. Philippine Islands ${ }^{397}$ the Supreme Court, looking to the appointment clause of the Constitution to interpret corresponding provisions in the Philippine Organic Act, ${ }^{393}$ placed strict limits on nonlegislative activity of legislators. Springer involved the statutory designation of members of the Philippine legislature to vote stock in government controlled corporations. While finding it unnecessary to determine whether members of the committee were "public officers in a strict sense,"390 the Court held that the presense of legislators on the committee was invalid because of the non-legislative powers they were authorized to exercise. Broadly interpreting the separation of powers provisions of the Philippine Orgamic Act, which it analogized to like provisions of the United States Constitution, the Court determined that for the purpose at liand the activities of the committee, not being legislative or judicial, were executive in nature. ${ }^{400}$ The Court then stated: "Not having the power of appointment, unless expressly granted or incidental to its power, the legislature cannot engraft executive duties upon a legislative office, since that would be to usurp the power of appointment by indirection . . .."401 Springer thus took a broad view of the concept of "officer" where legislators attempted to exercise a power they had created theinselves. The Court's position supports a de-

394. 306 U.S. 1 (1939). See text at note 142 supra.

395. A statement of the Supreme Court in United States v. Hartwell, 73 U.S. (6 Wall.) 385 (1867), has been read by supporters of the committee veto as distinguishing the position of a committee member from that of an officer of the United States. In Hartwell, the Court, describing rather than defining the concept of "officer," stated: "The term embraces the ideas of tenure, duration, emolument, and duties." Id. at 393. Thus it may be argued that a committee member, who receives no emoluments for his additional duties, cannot be ealled an officer. Hartwell, however, was a criminal case, where the question was whether an individual came under the coverage of a statute governing the conduct of "officers" for the purpose of imposing criminal sanctions. See note 106 supra. It is appropriate that in such case construction of the term should be narrow. Where the question is one of separation of powers, however, different principles apply.

396. U.S. CoNST. art. II, \& 2, cl. 2.

397. 277 U.S. 189 (1928).

398. See text accoinpanying note 130 supra.

399. 277 U.S. at 203.

400. See text accompanying notes 124-34 supra.

401. 277 U.S. at 202. 
termination that a holder of power under a committee veto statute acts as an officer of the United States, and that the statute specifying the individual to exercise this power is invalid as an infringement of the appointment power reserved by the Constitution to the other two branches of government.

Committee veto statutes may also be viewed as unconstitutional under the inconipatibility clause. By designating the individuals who are to exercise power by position rather than by name, a committee veto statute necessitates the exercise of powers establishing a legislator as an officer concurrently with his holding of legislative office. ${ }^{402}$ Thus, the statute violates the principle that no person may simultaneously exercise power as a nrember of the national legislature and as holder of another public office. In the one judicial interpretation of the incompatability clause, in Reservists Committee to Stop the War v. Laird, ${ }^{403}$ Judge Gerhard Gesell interpreted that clause in the same spirit the Springer court had applied to the appointment clause. The decision was affirmed without opinion by the Court of Appeal for the District of Columbia but was later dismissed for lack of standing by the Supreme Court. ${ }^{404}$ Reservists dealt with the issue whether a Congressman's commission in the military reserves violated the incompatability clause. Taking guidance from the constitutional debates, Judge Gesell noted that: "Where Congress is concerned, . . . the incompatibility clause must be applied in the light of the purpose of the Framers, who erected an inflexible barrier agamst Congressmen holding or being appointed to any other office under the United States."405 Recognizing that the object of the clause is conflict of interest, he added: "[A] showing of actual favoritisin or conflict of interest is not necessary to effectuate the purpose of the Clause."408 Judge Gesell concluded that where the issue was simultaneous membership in the reserve and in

402. If Congress had the power to name an officer by statute, its designation of a member of Congress by name would presumably vacate the member's seat upon his acceptance of the powers conferred. This follows from the wording of the incompatibility clause: "[N] o Person holding any Office under the United States, shall be a Member of either House during his Continuance in Office." U.S. CoNST. art. I, $\$ 6$, cl. 2. By specifying a meinber by position rather than by name, the statute makes such vacation of legislative office impossible. The statute must therefore be deemed inconsistent with the constitutional provision. Furthermore, where a legislator steps into a position of power which was created during his term of office, he violates the ineligibility clause. Id.

403. 323 F. Supp. 833 (D.D.C. 1971).

404. Schlesinger v. Reservists Committee to Stop the War, 418 U.S. 208 (1974).

405. 323 F. Supp. at 838.

406. Id. at 837. Willingness to find violation of the constitutional provision upon showing of potential, as opposed to actual, conflict of interest was essential to the holding of the case, for the court had demied plaintiffs discovery of the Pentagon's files, which meant there could be no showing of the activities of individual Congressmen in the Reserve. 
Congress, the former must be considered an office within the meaning of the incompatibility clause, and that such dual membership was impermissible. While Reservists was reversed for lack of standing, its reasoning on the merits supports the conclusion that a committee veto statute is unconstitutional because it confer's officer status upon a nnember of Congress within the meaning of the incompatibility clause.

Under the principles enumerated in Section III of this Comment, any use of the committee veto must be judged invalid. The critical problem is that the device creates a conflict between personal or local interest and the national interest. Furthermore, since there appears to be no check for abuse in the various areas where a committee veto might be used, such statutes should be per se invalid.

\section{Informal Committee Powers}

One response to presidential condenunation of the formal committee veto has been resort to informal committee control, often facilitated by a "report and wait" provision. ${ }^{407}$ The effectiveness of informal committee control ${ }^{408}$ raises the question whether concern over the formal might be nugatory. Congressional exercise of informal control over admimistrative action evades effective constitutional condemnation, yet such pressures unay be expected to have many of the effects of the committee veto. If the "standard legislative practice" from which the "impact" of the committee veto is determined is taken to imclude informal committee control, then that impact may be less than was indicated in the previous subsection of this Comment. ${ }^{400}$ However, the difference between the two forms of control is one both of principle and of practicality and justifies adhering to the condemnation of the formal committee veto.

407. A "report and wait" provision requires an administrator to report proposed action to Congress or to a congressional committee and wait a specified time before proceeding. Recently enacted provisions of this type may be found in the following statutes: Act of June 22, 1974, Pub. L. No. 93-316, §§ 3, 4, 88 Stat. 242-43; Act of July 8, 1974, Pub. L. No. 93-333, § 4, 88 Stat. 290; Act of July 25, 1974, Pub. L. No. 93357, § 8, 88 Stat. 392; Act of Aug. 30, 1974, Pub. L. No. 93-400, \& 8, 88 Stat. 798; Act of Sept. 4, 1974, Pub. L. No. 93-413, \$ 6, 88 Stat. 1094; Act of Oct. 5, 1974, Pub. L. No. 93-435, $\S 1$ (c), 88 Stat. 1211; Act of Oct. 11, 1974, Pub. L. No. 93-435, 88 Stat. 1262; Act of Dec. 27, 1974, Pub. L. No. 93-552, §§ 501, 603, 88 Stat. 1757, 1760; Act of Dec. 31, 1974, Pub. L. No. 93-577, § 8(f), 88 Stat. 1887.

408. See HARRIS, supra note 12, at 213.

409. The "impact" of a procedure employed by a statute is determined by comparing results that may be obtained with the procedure with those that may be accomplished by standard legislative techniques. See text accompanying note 370 supra. If the baseline for determining impact is standard legislative procedure coupled with informal control, the impact of formal control may be found to be small. That this is not the proper baseline is shown in the text accompanying note 414 infra. 
Though the effects of informal congressional pressures are effects the Framers strove to avoid through careful definition of government structure, it is nevertheless difficult to conclude that such activity, however improper, is unconstitutional. It is inconceivable that the Framers intended no informal contacts between legislators and administrators. Assuming that there was in fact no such intent, such contacts are themselves permissible, and informal control may be condemned only by holding invalid some statute or procedure analogous to the committee veto authorization on which the practice depends. The only apparent candidate is the report and wait provision. Yet this provision services only a fraction of the instances where informal control is important, and it may also be employed to legitimate ends. ${ }^{410}$ Moreover, a report and wait provision, unlike the committee veto statutes, formalizes no procedure which might be said to violate the Constitution. The subsequent incidental actions of Congressmen may be questioned only on a case-by-case basis by invalidating the resulting admimistrative decisions. ${ }^{411}$

410. The provision has been employed to allow time for legitimate respose to a proposed action through enactment of legislation. See, e.g., Act of Mar. 30, 1973, Pub. L. No. 93-12, 87 Stat. 9 (proposed rules of evidence not to take effect).

411. In tivo court of appeals cases administrative decisions have been invalidated as a result of improper congressional influence. In Pillsbury Co. v. FTC, 354 F.2d 952 (5th Cir. 1966), the Chairman of the FTC had appeared before the Subcommittee on Antitrust and Monopoly of the Senate Committee on the Judiciary during the pendency of a case involving Pillsbury before the Commission. The Commission had earlier issued an interlocutory opinion in the case reversing the hearing examiner and determining that the Government had presented a prima facie case against Pillsbury for violation of section 7 of the Clayton Act. The opinion rejected the Government's argument that a "per se" test rather than a "rule of reason" test should be applied in determining whether Pillsbury's activities resultd in a "substantial lessening of competition." The hearing examiner had yet to rule on the merits, and the Commission had made no final ruling.

During the hearings, several members of the subcommittee forcefully expressed the opinion that the Commission should have found the "per se" test applicable to the Pillsbury case, and berated the chairman for having allowed the Commission to reach a result contrary to the congressional intent in passing section 7. Subsequently, the Commission found that Pillsbury's actions had violated section 7.

The court of appeals agreed with Pillsbury's contention that the Senate subcommittee proceedings had so prejudiced the Commission as to deprive the corporation of its due process right to a fair and inpartial adjudication. Carefully observing that normally no constitutional issue is raised by committee pronouncennents as to what agency policy should be, the court ruled:

[W] hen such an investigation [as a congressional hearing] focuses directly and substantially upon the mental decisional process of a Commission in a case which is pending before it, Congress is no longer intervening in the agency's legislative function, but rather, in its judicial function. At this latter point, we become concerned with the right of private litigants to a fair trial and, equally importaut, with their right to the appearance of impartiality, which cannot be maintained unless those who exercise the judicial function are free from powerful external influences.

Id. at 964 (einphasis in original). Noting the passage of time since the hearing and 
While there are important practical differences between formal controls and informal controls, including those aided by a report and wait provision, the fundamental distinction is one of principle. Under a committee veto statute an administrator is bound by law to follow committee directives. Where the committee has no power but the power of persuasion, buttressed though it niay be by the power of the purse, the final authority is that of the administrator. Often he will follow committee desires, ${ }^{412}$ but he has the discretion to deviate. The committee thus

the change of personnel on the Commission, the court remanded the case for a new decision.

The adjudicative context of the Pillsbury case distinguishes it from the more general question of committee influence over administrative decisions. Nevertheless, the principle behind the case-that the congressional intent with regard to how laws are to be applied is to be gleaned fron general legislative history and statutory language rather than from the hindsight of a few strategically placed legislators-should be applied beyond the facts of Pillsbury.

In D.C. Federation of Civic Associations v. Volpe, 456 F.2d 1231 (D.C. Cir. 1972), a result analogous to that in Pillsbury was reached. In that case, the Secretary of Transportation had been required to exercise his discretion to decide whether a proposed bridge project complied with all statutory requirements, and should be approved. One of the issues in the case was whether Secretary Volpe's approval of that project was "tainted" by lis consideration of "extraneous factors unrelated to the merits of the question presented"-in particular the threat of Representative Natcher, Chairman of the Subcommittee on the District of Colunibia of the House Appropriations Committee, to cut off funds for construction of the District's subway system if the bridge was not approved. Id. at 1258 .

Chief Judge Bazelon, writing for the court, first approved the trial conrt's finding that Secretary Volpe was not acting in a judicial or quasi-judicial capacity. Plaintiffs could not, therefore invoke the doctrine of Pillsbury that even the appearance of bias or undue political pressure could invalidate an agency's adjudicatory decision. Bazelon went on to note that if the Secretary's action was legislative in character, his decision would stand in spite of a finding that he had considered extraneous pressures. The judge was unwilling to label the decision purely "legislative," however, "since Congress had already established the boundaries within whicl his discretion could operate." Id. at 1247. He then stated:

[T]hough his action fell between these two conceptual extremes [of "judicial" and "legislative" action], it is governed by principles that we had thought elementary and beyond dispute. If, in the course of reaching his decision, Secretary Volpe took into account 'considerations that Congress could not have intended to make relevant,' his action proceeded from an erroneous preinise and his decision cannot stand. The error would be more flagrant, of course, if the Secretary had based his decision solely on the pressures generated by Representative Natcher. But it should be clear that his action would not be immunized inerely because lie also considered sone relevant factors.

Id. at 1247-48. Considering the Secretary to have keen influenced by extraneous pressure, the court rentanded the case for new determinations based on the inerits, without regard to factors not made relevant by Congress in the applicable statutes.

While Judge Bazelon's opinion inight be taken as suggesting that a different result might obtain liad Congress intended such pressures be taken into acconnt, the court had before it no suggestion that such intent night itself be invalid under the committce veto analysis presented here. Such invalid intent could not be presumed if unexpressed, and if expressed it would return the issue to the formal cominittee veto situation.

412. But see the cases discussed in note 411 , supra. 
lacks final authority. While the committee may have great power, it does not exercise what Mechem termed "some portion of the sovereign functions of government." ${ }^{13}$ Since its power may be effectuated only at the discretion of a member of the executive branch, there exists a means by which the power may be checked. Thus, in the case of informal influence the power of individual Congressmen or committees is limited by the scope of executive tolerance. A committee which is given formal statutory powers, however, suffers no corresponding limit on its activities. Its power is unchecked.

That congressional exercise of influence in governmental affairs may not be prevented on constitutional grounds does not justify accepting such activity as a standard legislative practice to be used as a base line for determining the impact of the formal committee veto. ${ }^{414}$ Like a committee veto, exertion of informal influence by a Congressman or committee constitutes extra-legislative activity. That this activity is beyond the reach of the Constitution is an imperfection in the scheme of the Framers; such influence has the potential for effecting results that contravene the goals of the Framers and should be regarded as improper, if not invalid. The standard which should be used to evaluate the committee veto is that framed by the accepted legislative process, not including extra-legislative activity. To conclude that since these effects may be achieved without use of the committee veto, the committee veto itself has no effect is to bootstrap the demise of the principles developed in Section III. It is important to recall that, while there are distimctions between formal and informal control, the likely effects of informal committee influence do violate the purposes of the Framers. Instead of permitting the informal procedure to justify use of the committee veto, this basic infirmity emphasizes the import of restraining the formal procedure so as to provide a means for containing informal pressure. Although the case-by-case invalidation of administrative decisions subject to undue congressional pressures, as has been attempted by two Courts of Appeal, ${ }^{415}$ provides some opportunity for controlling extreme misuse of informal pressure, it is unlikely to have significant deterrent effect. A firm recognition of the imvalidity of the formal committee veto, however, will give administrators support in resisting improperly motivated pressures wherever they may arise.

\section{The "No Appropriation" Clause and the Committee Veto}

In response to presidential criticisin of the committee veto and at

413. See note 392 supra.

414. See text accompanying note 370 , supra.

415. See note 411 supra. 
the insistence of Senator Dirksen, ${ }^{418}$ the "no appropriation" clause has been substituted for the formal committee veto in some appropriation authorization acts. Utilizing the two-stage appropriation process, the device authorizes a subsequent appropriation, but specifies that such appropriation may not be made until approved by committees of Congress named in the authorizing statute. The "no appropriation" clause thus expresses a direction to Congress rather than to an administrator, since it is Congress which must enact the subsequent appropriation. ${ }^{417}$

The device was accepted by Presidents Eisenhower and Nixon ${ }^{418}$ and has been opposed only by President Johnson, who conceded that the device was not technically unconstitutional. ${ }^{410}$ Indeed, the "no appropriation" clause seens to fall squarely under the aegis of that clause of the Constitution granting Congress power to specify rules for the governance of its own imternal legislative processes. ${ }^{420}$ Though expressed in statutory form, ${ }^{421}$ the "no appropriation" clause is equivalent to the customary rule requiring that all appropriations commence with the House Appropriations Committee.

Like the committee system itself, the "no appropriation" device gives congressional committees leverage by which to exert pressure on administrators. This creates the potential for direct influence on government by the local interests which the Framers sought to confine within the body of Congress. ${ }^{422}$ It appears, however, that the "no appropriations" clause could fall only with the entire committee system which is generally considered a valid outgrowth of the rulemaking power.

Moreover, while the effects of the "no appropriation" clause and the formal committee veto may be similar in certain circumstances, there exists a fundamental difference between the two devices. The committee acting pursuant to a "no appropriation" clause, unlike the committee exercising a committee veto, is engaging in the formulation of legislation. Before the committee's work becomes law, it must be reviewed and approved by all of Congress, and is subject to presiden-

416. See text at notes 202-05 supra.

417. Of course, the clause cannot prevent congressional appropriation. Should Congress proceed to appropriate in the face of committee disapproval, the appropriation would simply amount to a repeal of the no appropriation clause to whatever extent necessary. The clause would presumably render such an attempt to appropriate vulnerable to point of order on the floor of either House, just as would an attempt to appropriate without prior authority.

418. See text at notes 204 and 243 supra.

419. See text at note 226 supra.

420. U.S. CoNST. art. I, \& 5, cl. 2.

421. It is not uncommon for Congress to specify that a particular statutory section is enacted under the rulemaking power. See note 441 infra.

422. See text accompanying note 258 supra. 
tial veto. Although Congress' review of particular measures may be cursory, and may not constitute actual approval of the committee's work, the possibility of review and check is present. That local bias may find its way into law as a result of committee work is an imperfection in the system akin to the possibility of presidential bias. ${ }^{423}$ The Constitution presumes that its "averaging process" is sufficient to weed out the product of local bias. The inaccuracy in this presumption which arises from the working of the committee system within the legislative process must be tolerated as an imperfection in the plan of government formulated by the Framers, but not as an excuse for violating that plan with the committee veto.

\section{B. The Constitutionality of Statutes Authorizing Simple and Concurrent Resolutions}

The statutory authorization of congressional action by simple or concurrent resolutions presents a more difficult question than does the committee veto. While there is little judicial authority to reference in determining constitutionality in either case, the committee veto statutes generally have the illicit effect of creating a conflict of interest between the national interest and local interest. No such generalization is possible where resolutions are employed for extra-legislative control. While avoidance of "constitutional averaging" may be present where resolutions are employed, conflict of interest is likely to be subdued where the Houses of Congress are required to act as umits, and the requirement that Congress take some positive action by concurrent resolution fully satisfies the bicameral principle. ${ }^{424}$ Nor does there seem to exist any other effect justifying per se condemnation of the use of resolutions. In the absence of both judicial authority and cause for blanket condemnation, the uses of resolutions to effectuate the desires of Congress must be examined imdividually to discover transgression of the purposes of the Framers.

After dealing with the threshold question whether all uses are banned by the literal language of the Constitution, this section discusses in general the purposes of resolutions authorized by the statutes under consideration and classifies their impacts on congressional power. The section then discusses impact and validity for particular classes of cases.

423. See note 378 supra.

424. The meaning of bicameralism is somewhat cloudy in situations, apparently not visualized by the Framers, where Congress is placed in the position of disapproving rather than approving measures. Does the bicameral principle in this situation require that each House have the power to defeat the measure (veto by simple resolution), or that either House may negate the action of the other (veto by concurrent resolution)? See text accompanying notes $446-48$ and 449 infra. 
This analysis will, for each class of statutes considered, follow the framework developed earlier. Impact will be determined by comparing the results possible under the questioned procedure with what might be achieved under standard legislative practices. ${ }^{425}$ The differential in power will be evaluated under the four criteria, and any conclusion as to the invalidity will be articulated in terms of specific constitutional provisions.

The Constitution requires that all votes for which the concurrence of the two Houses is necessary be presented to the President. While it is possible to read this language literally, the Senate report of $1897^{420}$ rejected this reading and concluded that the word "necessary" in the veto clause refers to "constitutional necessity," not a necessity resulting froin practice or statute. The authors of the Senate report considered this determination of "necessity" to turn upon whether the vote in question was "legislative" in nature. This approach, which has consistently represented Congress' interpretation of the veto clause ${ }^{427}$ since 1897 , is the approach adopted in this Comment, except that constitutional necessity will be derived from the constitutional criteria rather than from a conclusory label. ${ }^{428}$ If a statute authorizing a later resolution has an effect on power imconsistent with the purposes of the Framers as expressed in the four criteria, then it is unconstitutional under the analysis of this Comment. It may then be characterized as one which authorizes a later decision for which concurrence of both Houses and approval by the President are "constitutionally necessary" because of the potential abuses of power which may result if such procedure is not followed. Because the statute authorizing the resolution evades these safeguards, it must be judged unconstitutional under the clause requiring presentation to the President.

As demonstrated earlier in this section, ${ }^{420}$ it is possible to characterize the potential impact of statutes authorizing extra-legislative activity in three different ways: such a statute may preserve momentary congressional power; it may vest a discretionary power in Congress; or it may avoid the "constitutional averaging process." Prior to discussing particular uses of statutes authorizing subsequent resolutions, it will be

425. See text accompanying note 370 supra.

426. See note 56 supra.

427. U.S. Const. art. I, \& 7, cl. 3.

428. This approach allows concurrent and simple resolutions to be treated on the same plane. It verges on irrationality to maintain that action by concurrent resolution, whereby Congress is at least held in check by its own structure, is invalid because the veto clause so states, but that the invalidity of a simple resolution, wherein a single House acts without check, is more in doubt.

429. See text accompanying note 372 supra. 
useful to indicate how these three categories of impact might apply to these statutes.

A statute nay authorize subsequent congressional action by resolution not subject to veto in order to preserve the power of Congress existing at the time the statute is passed. The authorizing statute inust itself be approved by the President or passed over his veto. ${ }^{430}$ The override of a veto requires that two-thirds of the membership of each House favor enactment at the time of reconsideration. ${ }^{431}$ Presidential approval of the original statute may follow from his actual favor of the measure at that particular time, or from the leverage which Congress is able to assert through ineasures to which the resolution provision is appended. ${ }^{432}$ In either case-whether there be override of a veto or presidential approval-the authorizing statute preserves the power possessed by Congress at one instant in time for a later time when the Congress might otherwise be unable to act because of presidential disapproval or non-concurrence between the two Houses.

Alternatively, this type of statute may be designed to create a power of oversight over the executive, relieving Congress of the duty to specify standards for executive action in advance. If Congress is unhappy with executive decisions in particular factual settings, the authorizing statute allows it to compel a different result by the pas-

430. As there seems no room in this constitutional scheme for a statute valid on presidential approval, but invalid if passed over his veto, these possibilities will have to be considered together. The suggestion of Newman and Keaton in reponse to Ginnane that the presentation to the President of the authorizing bill is sufficient to satisfy the veto clause-in effect that the President may consent to provisions authorizing later resolutions-and that validity in case of override follows froin validity in the case of approval, is overly simplistic. See Newman \& Keeton, Congress and the Faithful Execution of Laws-Should Legislators Supervise Administrators?, 41 CALIF. L. REV. 565, 587 (1953). If analysis reveals effects in these measures in derogation of the system envisaged by the Framers, it slould not be competent for the President to consent to them. The President must be viewed as holding the powers of the executive in trust and as incapable of validly waiving his right to veto measures enacted by Congress.

Newman and Keaton also suggest that congressional competence to delegate powers to the House and Senate may be read from the validity of delegations to public officials and private groups. Id. at 588. This is a non sequitur. See the discussion of Currin v. Wallace, 306 U.S. 1 (1939), at note 140 supra. Before reaching this conclusion the effect on power must be examined once again. A delegation which disperses power is not necessarily constitutionally equivalent to one which concentrates power in the hands of the delegating agency.

431. This is exemplified by the War Powers Resolution, Pub. L. No. 93-148, § 5(1), 87 Stat. 555 (1973), which preserves the power of a two-thirds majority accrued at a time of high emotion.

432. The Lend Lease Act, for example, was approved by the President out of political necessity. See text at note 157 supra. It preserves the power of Congress resulting from this necessity for a time when there may be no comparable force coercing the President's approval. 
sage of a resolution. ${ }^{438}$ Where a statute is designed to allow Congress such an extra-legislative discretionary response to particular fact situations, this too is an impact which must be analyzed.

Finally, one would not expect a statute authorizing congressional action by simple or concurrent resolution to mask a clandestine desire to effectuate local interests, though in some circumstances a resolution provision may bypass the bicameral check and thus have the effect of enhancing the power of factions. Action by a House of Congress is an imperfect tool for seeking predictable local advantage. This imperfection is amplified when the underlying statute authorizes action by either House. Nevertheless, in each instance where a statute authorizes a later resolution, the possibility of this impact must be considered and evaluated in light of the four criteria.

\section{Reaction to Administrative Proposals-The "Laying System"}

An area in which control by resolution has been strongly advocated among commentators is the field of admimistrative lawmaking. ${ }^{44}$ The system proposed by these authors would be patterned after the "laying system" of Great Britain, whereby proposed administrative regulations are laid before Parkament for examination before becoming effective. $^{435}$ Proposed systems range from simple report and wait practices to provisions requiring affirmance by resolution of the proposed regulations or permitting disapproval within a specified time. ${ }^{430}$ Several states have experimented with the laying system as a general procedural device, ${ }^{437}$ and Congress has adopted it in a few specific in-

433. Thus the reorganization acts give the President broad authority to reorganize the governmeut by decree, but create a veto right in the Congress. See text at notes 114-15 supra. The Immigration and Nationality Act, ch. 477, \& 244(b), (c), 66 Stat. 163 (1952), authorizes binding congressional approval or disapproval of certain administrative actions taken pursuant to the Act.

434. See Boisvert, A Legislative Tool for Supervision of Administrative Agencies: The Laying System, 25 ForD. L. REv. 638 (1957); Melville, Legislative Control Over Administrative Rulemaking, 32 U. CIN. L. REv. 33 (1963); Schubert, Legislative Adjudlcation of Administrative Legislation, 7 J. PUB. L. 134 (1958); Schwartz, Legislative Control of Administrative Rules and Regulations: I. The American Experience, 30 N.Y.U.L. REv. 1031 (1955); Stone, The Twentieth Century Administrative Explosion and After, 52 CaLIF. L. REv. 513 (1964); Note, "Laying on the Table"-A Device for Legislative Control over Delegated Powers, 65 HARv. L. REv. 637 (1952) [hereinafter cited as Harvard Note].

435. Statutory Instruments Act, $9 \& 10$ Geo. 6, c. 36 (1946). See Boisvert, supra note 434, at 638. The English system is discussed in Carr, Legislative Control of Administrative Rules and Regulations: II. Parliamentary Supervision in Britain, 30 N.Y.U.L. REv. 1045 (1955).

436. See Boisvert, supra note 434 , at 640 .

437. Sec ConN. GEN. STATS. ANN. \& 4-170, and § 171 (1974 Supp.) (administrative regulations may be disapproved by legislative committee, suject to reversal by General Assembly); ConN. Gen. Stat. ANN. \$ 51-14 (1958) (procedural rules promulgated by state supreme court subject to disapproval by general assembly); MrcH. CoMp. LAws 
stances. $^{438}$

This section first gives broad consideration to congressional response by resolution to administrative lawmaking proposals, then applies this general analysis separately to reorganization, presidential substantive rulemaking, and finally to administrative rulemaking im whicl the President does not participate.

When the President or an agency is authorized to submit a proposal to Congress for scrutiny, Congress' response may take four forms: (1) a statute could require the proposal be approved by concurrent resolution; (2) the statute could allow disapproval of the proposal by simple resolution in order to prevent it from automatically taking effect; (3) disapproval by concurrent resolution in order to defeat a proposal could be required; and (4) a proposal could become effective only upon approval by simiple resolution. These procedures may be paired according to a characteristic important to later analysis. If approval by concurrent resolution is required (first procedure), the proposal may be defeated by disapproval of either House. The same is true if instead the proposal is to take effect automatically unless disapproved by simple resolution (second procedure). Likewise, disapproval by concurrent resolution (third procedure) is analytically akin to approval by simple resolution (fourth procedure); in both cases the proposal will take effect if either House approves. ${ }^{439}$

\$ 24.251 (1974 Supp.) (disapproval by concurrent resolution); CODE of VA. $\$ 9-6.9$ (1973). Kansas formerly had such a provision, KANS. STAT. ANN. $\$ 77-410$ (1949), but it was later repealed. Kans. L. 1965, ch. 506, $\$ 40$ (June 30, 1965). A New Hampshire provision patterned after the federal reorganization acts, N.H. LAws (1949), ch. $43, \S \S 4,5,8,10$, was declared to violate the state constitution by the New Hampshire Supreme Court. Opinion of the Justices, 96 N.H. 517, 83 A.2d 738 (1950). See Melville, supra note 434, at 44-48. A Nebraska provision of this nature, Rev. STATs. NEB., 1943 , § 84-904 (reissue of 1971), has been repealed and replaced by a provision requiring legislation. Rev. Stats. Neb., 1943, § 84-904 (1974 Cum. Supp.). Finally, Wisconsin in 1953 passed a provision for annulment by resolution of administrative regulations, Wis. Stat. ANN. $\$ 227.031$ (1953), but the State Attorney General advised that the measure was unconstitutional. 43 Or. WIS., ATr'Y GEN. 350 (1954). The provision was replaced by one requiring report of regulations to a legislative committee, but giving that committee advisory powers only. WIs. STAT. ANN. $\$ 227.041$ (1957). This provision, too, was later repealed. Wis. L. 1957, c. $426 \& 4$. See Helstad, New Law on Administrative Rule Making, 1956 WIs. L. Rev. 407 (1956).

438. E.g., the federal rcorganization acts, see notes 114-15 and accompanying text; Emergency Petroleum Allocation Act of 1973, Pub. L. No. 93-380, 87 Stat. 627 (1973); Education Amendments of 1974, Pub. L. No. 93-380, § 509(a), 88 Stat. 484, 567.

Several of the commentators advocating the laying system have argued its constituionality, but in rather conclusory terms. Boisvert maintains: "If Congress can delegate power to the Executive without violating the Coustitution, why cannot that sane body, with equal authority, reserve or retain a certain small residue of its delegable power which it cau exercise itself? The power to retain is inplicit in the power to give away." Boisvert, supra note 434, at 657. The same author seems also to rely on an unofficial memorandum submitted by the Justice Department (see S. REP. No. 232, 81st Cong., 
The first step in the analysis of these ineasures is to isolate their actual impact on the distribution and extent of governmental powers by comparing them with lawmaking techniques that fall within standard legislative procedures. The two techniques which will be used as a base line for comparison will be labeled the "legislative scheme" and the "Executive scheme." It would no doubt be competent for Congress to authorize the President to submit a proposed set of regulations or a plan of reorganization. ${ }^{440}$ If both Houses approved, Congress could then enact the proposal, or could first amend the plan and then enact

1st Sess. 20 (1949)) in support of the 1949 reorganization act which suggests that the President's assent to the reorganization act is simply his undertaking to consult with Congress before utilizing his authority under the act. See Boisvert, supra note 434, at 660-61.

Schwartz, on the other hand, considers legislative approval (or non-disapproval) of administrative rule to be valid not as a legislative act, but as a mere contingency upon which the delegated rulemaking power is predicated. He additionally argues that if a retained annulment power is to be considered "lawmaking," then so is rulemaking itself, and a "rigid separation of powers approach" must also invalidate the delegation of rulemaking power to an independent agency. Schwartz, supra note 434, at 1043. Finally, a student comentator takes the position that the President's acquiscence in the original authorizing statute forsees and impliedly approves later congressional action. Harvard Note, supra note 434 at 646 . This position was later adopted by Newman and Keaton. See note 430 supra.

These arguments ignore the basic question of governmental power which must be addressed in evaluating the constitutionality of a laying system. Thus Boisvert, in arguing that what Congress may give away it may partially retain, ignores the fact that Congress "gives away" not merely a power which it had previously itself possessed, but a power which it has created anew-the power to make law without presidential involvement. To facilely argue that this power which Congress may "give away" it may also "retain" completely fails to analyze the possibility that this retention results in the creation and exercise of power by the same hand, a situation systematically avoided by the Framers. See note 292 supra.

Only Boisvert touches on the type of analysis to be followed in this Comment. He argues that in reality the laying system need effect no redistribution of power if the President may excrcise control over subinission of proposed regulations.

439. The procedures in each pair are distinguished inter se by the facts that: (1) one procedure in each pair requires affirmative congressional action while the other allows the administrative proposal to take effect automatically if Congress fails to act. That this does not automatically render the procedure iuvalid follows from the validity of congressional delegations of lawinaking authority without possibility of legislative review, but this difference will affect the nature of the descretionary control impact. Sec text accoinpanying notes 443-44 infra. (2) One procedure in each pair allows action by a single House of Congress without possibility of negation by the other House, while the other does not. This distinction relates to the Framers' purpose that bicanneralism serve as a check on legislative power and tendency to encroach upon the Executive. See text following note 444 infra. The distinction between the pairs, that procedures one and two allow a change in the law only with the concurrence of both Houses, whereas procedures three and four allow change in the law whenever a single House agrees, relates to the Framers' purpose that bicameralism serve as a means of "constitutional averaging." See text accompanying notes 449-51 infra.

440. Indeed, the Constitution itself authorizes the President to propose desired legislation to Congress. U.S. CoNST. art. II, \& 3. 
it. In either case, the resulting bill would then be submitted to the President for approval. Under their rulemaking powers, both Houses could provide that no amendment to the proposal would be in order and that the proposal would receive priority in both Houses to ensure that it reached the floor. In addition, a rule limiting or forbidding debate on the measure could be adopted by each House. Finally, there is little doubt that these rules could be expressed in the statute authorizing submission of the proposal. ${ }^{441}$ This hypothetical procedure for executive lawmaking adheres to standard, well-accepted legislative techniques, and will be referred to as the "legislative scheme." Alternatively, Congress might simply authorize the President to promulgate by Executive Order a set of regulations or a plan for reorganization, the plan to go into effect a specified period after submission to Congress. Under this scheme, Congress could disapprove the proposal only by legislation, enacted over the President's veto if necessary. This presumably valid delegation of authority to the President will be referred to as the "Executive scheme." Taking these two apparently valid models as prototypes for administrative lawmaking, this Comment considers in what ways the four possible laying systenis, in diverse contexts, might deviate in effect from either. For the present this Comment assumes that there is no mechanism for altering the president's proposal.

\section{a. Resolutions as Legally Effective Responses to Executive Lawmaking}

$i$. Generally. The three suggested impacts on power are preservation of congressional power, vesting of discretionary power in Congress, and avoidance of "constitutional averaging." 442 Where Congress is authorized to respond only to presidential proposals, none of the four procedures allows Congress to act independently of the President in a way that can be said to be preservative of congressional power, for Congress can only accept or reject the President's proposal. However, all the procedures, in a literal sense, create a post-legislative discretionary power -they allow Congress to respond to specific administrative actions other than through enactment of legislation. In addition, the procedures nay allow evasion of the "constitutional averaging" requirenent for congressional action.

(a) Impact-vesting of discretionary power. The extent of impact on federal power and its distribution will vary aniong the four procedures depending on the manner in which Congress may exercise

441. Congress has often incorporated provisions it considers to come under the rulemaking power into a statute. See, e.g., The Congressional Budget and Impoundment Control Act of 1974, Pub. L. No. 93-344, tit. IX, § 904, 88 Stat. 297. See also id. tit. III and tit. X, § 1017.

442. See text accompanying note 424 supra. 
its discretionary power. The first procedure may be characterized as having no true impact on power. Both the President, who formulates the proposal, and Congress, which passes upon the proposal, exercise power equivalent to that which they exercise in the "legislative scheme." The President has ultimate veto power through his formulation of the proposal. He will submit only proposals he approves, or he may refuse to submit any proposal. Congress will act favorably on the proposal only if both Houses approve. The first procedure may thus be terined "reverse legislation," for it inerely reverses in time the final exercise of power by the President and Congress. Since there is no constitutionally significant impact on government power, this procedure inust be judged a valid technique for responding to Executive proposals. ${ }^{443}$

Under the second procedure the two Houses of Congress and the President possess the same relative powers as under the first. Nevertheless, two factors distinguish the second procedure from the firstwith resultant consequences for impact on power and evaluation in light of the criteria. The same factors also distinguish the third procedure from the fourth. The first factor involves the nature of the control exercised. One member of each pair of procedures-first and second, third and fourth - would allow the President's proposal to take effect automatically should it fail to coine to a vote, whereas the other member of each pair would require positive action on the part of one or both Houses of Congress to effect the proposal. This distinction is significant with regard to impact on power because of the relative efficiency of the two types of response as control mechanisms.

In creating executive authority Congress may, of course, choose to allow absolute discretion to the executive in the exercise of that authority. Ordinarily this will be prevented by interbranch jealousy-one of the fundamental checks of the Constitution. Congress, therefore, will seek either to limit the power it creates or to retain control over that power. It is faced with a choice between miposing general standards for authorized executive activity in order to limit the power created or accepting the burden of repeated legislation of authority for executive action in individual instances. The institution of extra-legislative control devices broadens congressional choice.

443. President Ford, however, recently objected to a variant form of "reverse legislation" in which a provision of an act would have authorized later effectuation by concurrent resolution not of a presidential proposal, but of the same act which the President was asked to sign. In vetoing the Atomic Energy Act amendment the President termed it the mere announcement of an intention to legislate. See note 160 supra. The bill indeed would have had impact beyond that of the measures under consideration, allowing an idefinite delay in the congressional decision. This would have a preservative impact on power in contrast to the "laying systein" which contemplates congressional response within a specified time after presidential action. 
If a control device requires congressional response to every administrative action subject to control, this indeed has the effect of allowing congressional control of the details of administrative action. This is the case with procedures one and four. This control could equally have been achieved, however, by the requirement of individual legislative authorizations. A requirement of positive legislative response is an unwieldy tool for control when administrative action is expected on a regular basis, whether the response required is legislative or extra-legislative. Mere replacement of legislative response with extra-legislative response will not broaden Congress' ability to control or create federal power.

Instead of simply replacing legislative response with an extra-legislative response, the second and third procedures create the possibility of passive congressional control. If Congress need respond only when it disapproves of administrative action, administration may run its dayto-day course without interference; yet Congress always retains control. This is much more efficient than active control, involving item-by-item approval, but this efficiency nay be the constitutional downfall of a passive control procedure. Under such a device, Congress can legislate without imposing standards on administrative actions. The executive branch thus receives power greater than that which it would otherwise obtain, subject only to the condition that when exercised, the power not be exercised in such a way as to evoke a congressional veto. The result of this passive control mechanism is the creation of powers which otherwise would not be created, to be exercised by the President and Congress in concert. As a unit, these two branches inay enjoy a greater power than would otherwise be possible. ${ }^{444}$ This first distinction between nnembers of each pair will be of importance, then, when the cir-

444. This point may be illustrated by the following example. Consider a series of hypothetical statutes: (1) "The President, in his discretion, may have any individual widgetized." This statute would obviously not be favored by the legislative branch in that it would give the President too great a power over which it had no control. Rather, Congress would be likely to impose standards for executive discretion: (2) "The President may have any individual widgetized who has been found guilty of crime X." This statute, not entirely free of problems, is much more likely-it imposes limits on the President's power. But suppose instead Congress pronounced that: (3) "The President may have any individual widgetized, subject to disapproval of either House." This statute would satisfy Congress, at least as to any concern over its own power. It would ensure that the President's power would not be exercised in any instance where contrary to the desires of either House. Yet it is clear that the President and Congress combined share greater power than in the case of the second statute. The only way such a combination could be approximated by more standard procedures is to have the President submit each proposed widgetization to Congress and (disregarding bill of attainder problems) have that body enact his proposal into law. This would require that Congress act in each instance, and would be a much less effective device for increasing power. 
cumstances for which the extra-legislative activity is authorized reveal danger of increased exercise of federal power. This danger may exist where congressional response to Executive proposals is authorized as a means of control, but this will depend on the particular context of control.

The second factor which distinguishes members of the two pairs inter se in terms of impact is the fact that one member of each pair allows action by a single House which may not be negated by action of the other. The significance of this must be determined in light of the principle of bicameralism. However, that principle was formulated to operate in a context where Congress simply enacts laws; its application is difficult where Congress acts only in response to administrative action. There are further conplications where the authorized action involves rejecting a measure, rather than acting to approve it. Therefore it is possible to apply the "principle of bicameralism" to the present situation only by considering the purposes for which the Framers adopted a bicameral system.

The principle of bicameralism has received two formulations: (1) that any action by one House may be negated by action of the other, ${ }^{446}$ (2) that each House of Congress has the right that there be no change in the law without its consent. ${ }^{446}$ These two formulations appear to correspond to the two purposes identified in Section III as underlying bicameralism. ${ }^{477}$ The first formulation focuses on the process of congressional action, the second on the result of that action. The first corresponds to the Framers' purpose that the two Houses act as mutually retarding forces so as to prevent domination of the executive by the legislative branch, and is unrelated to the idea of "constitutional averaging." The second formulation deals with "constitutional averaging" of interests and will be dealt with later in the analysis. Only the first formulation distinguishes inter se the members of the pairs. ${ }^{448}$ This distinction will be of importance only when there is a theoretical danger of legislative domination of the Executive. This is not the case where Congress may only respond to Executive proposals. Consequently, in the context of Executive lawmaking distinctions in mupact due to vesting of discretionary power will turn primarily on the distinction between active and passive control.

445. See 2 FARRAND, supra note 250, at 197 (statement of Mr. Madison).

446. "[S]uch a delegation of legislative power does not operate to deprive either House of its Constitutional right to have no change made in the law relating to organization of the government without the asset of at least a majority of its members present and voting." S. REP. No. 638, 79th Cong., 1st Sess., quoted in Ginnane, supra note 13 , at 581 n. 46 . See also Ginnane at 598.

447. See text accompanying notes $260-90$ and 336 supra.

448. See note 439 supra and accompanying text. 
(b) Impact-avoidance of "constitutional averaging." Since the four procedures under examination involve only actions by entirehouse units, the final impact, the possibility of avoidance of "constitutional averaging," may be assessed in terms of whether a single House is given power inconsistent with the principle of bicameralisin. As indicated above, the second formulation of bicameralism-that each House of Congress has the right that there be no change in the law without its consent-relates to the need for "constitutional averaging." One purpose of the Framers in establishing a bicameral system was to prevent domination of the legislature by a single set of interests, such as those of the heavily populated states. The second formulation, requiring that every measure emanating froin the Congress have the the assent of both its Houses, corresponds to that purpose.

This second formulation is properly articulated as applied to the standard legislative process, but it is clearly incorrect in the context of the Executive sclieme, where the President is authorized to change the law with the assent of neither House. Furthermore, in situations where Congress may only respond to an external proposal, the stateinent is more restrictive than necessary to achieve the Framers' purpose. The basic fear is that a measure formulated by a House dominated by one set of interests miglit take effect without approval of the second combination of interests represented by the other House. If the President, regarded by the Constitution as neutral with respect to local interests, ${ }^{449}$ may formulate a plan or set of regulations and have them take effect automatically, then the validity of the process should not be affected by the fact that approval by a majority of a single House is required for the President's proposal to stand. ${ }^{450}$ The second forınulation may thus be restated to suit the present context: No measure formulated by one House of Congress may take effect unless also approved by the other. ${ }^{451}$

Both the first and second procedures satisfy either statement of the "constitutional averaging" formulation of bicameralism. In neither case can a proposal take effect if opposed by either House of Congress.

449. See note 289 supra.

450. Indeed, in the executive scheme, where Congress can disapprove the President's proposal only by legislating, the President may assure effectuation of his proposal by gaining the support not of a majority of a single House, but by gaining support of one-third of one House necessary to prevent override of his veto.

451. A measure is "formulated" by a House if that House has a hand in the drafting of the measure. In this sense legislative measures are generally formulated by both Houses, and must receive the assent of both. Ordinarily one would not think of a measuse subinitted by the President as formulated by a House of Congress. However, where the President finds it necessary to submit to pressure and prepare his proposal to the specifications of a single House, this indirect formulation by a House may be sufficient to require the assent of the other. 
The third and fourth procedures violate the original statement of the "constitutional averaging" formulation but fall within its restatement, provided that neither House plays a part in the President's formulation of his proposal.

(c) Impact-a summary for the four procedures. Before beginning consideration of the validity of these four procedures in particular contexts of use guidelines may be establislied for analysis based on the foregoing considerations. The first procedure used in response to a presidential proposal involves "reverse legislation" and should be of little impact, provided that the President retains actual supervision over submission of the proposal. The second procedure, disapproval by simple resolution, retains the balance of power between the President and Congress. There is no danger of legislative dominance of the Executive. If there is to be an objection to the second procedure, it must stem from the passive nature of the control allowed by the procedure and the resulting potential for increase in federal power. Since the procedure presents no problem with respect to "constitutional averaging," the local imterest criterion should be satisfied, and there seems no likelihood for gratification of self-interest not present in the legislative process itself.

The third procedure (disapproval by concurrent resolution) is distinguished from the fourth (approval by simple resolution) by the passive nature of the resulting control. However, the distinction between this pair on the basis of active versus passive control is less than that between the first and the second procedures. The requirement of concurrence between the two Houses in order to veto the President's proposal renders the third procedure less effective than the second as a mechanism for control. Thus it can be expected that relaxation of standards for Executive action under the third procedure would be less than that under the second. If the only constitutional problem with disapproval by concurrent resolution involves the increase of federal power, the validity of the procedure will be a closer question than the validity of the second procedure-disapproval by simple resolution.

The third and fourth procedures apparently satisfy the "constitutional averaging" formulation of bicameralism in that the original proposal is made by the President, and does not originate in either House. The President, lowever, faced with the urgent necessity of obtaining approval of a single House, may be influenced by the desires of the House in whicli he has greater support. This type of congressional participation may violate the "constitutional averaging" requirement and give a single House power not allowed it by the bicameral primciple.

ii. Reorganization. The reorganization acts generally authorize the President to formulate and subimit to Congress a plan for reorgan- 
ization of the executive branch of government. The prescribed congressional reaction may be any of the four procedures previously discussed. The first procedure, adoption of the President's plan by concurrent resolution, has not been employed by Congress. Its use would be without impact on power, and would therefore be valid. The second procedure, disapproval by simple resolution, was employed by Congress in the 1932 and 1949 reorganization acts. ${ }^{452}$ This procedure allows passive congressional control over reorganization plans presented by the President. However, there appears hittle possibility that use of this procedure in the reorganization context might result in increased exercise of federal power: the power to reorganize executive departments is not a substantive power through which government acts on the subjects of government; it is merely the power to decide how to govern. ${ }^{453}$ The second procedure as utilized in the reorganization acts therefore violates none of the constitutional criteria and should be considered valid.

A more difficult problem is presented by the third and fourth procedures. These procedures confront the President with the requirement that his action receive the blessing of one House of Congress, but not necessarily of both Houses. To exercise the power given him, the President may find it necessary to yield to the desires of one House. Thus, the resulting plan is in part the product of the favored House, and may become law without review by the other House. Without inore, this should lead to a fimding of constitutional invalidity. However, there are mitigating considerations in the case of reorganization which lead to the somewhat reluctant suggestion that procedures three and four may be grouped with the first two as permissible congressional tools for facilitating governmental reorganization. Most important among these considerations is the well-defined nature of the reorganization acts. Validation of extra-legislative procedure here need not presage irresistible expansion of use. Furthermore, reorganization is generally carried out in discrete, unrelated steps. The President will have greater freedom not to act than may be available in administration of an ongoing program. This freedom may enable the President to avoid domination by a single House in formulation of a plan. Moreover, the President's own vital interest in the organization of the executive branch is likely to lead him to resist domination. Finally, re-

452. Legislative Appropriation Act of 1932, ch. 314, $\S 407,47$ Stat. 414; Reorganization Act of 1949, ch. 226, \$ 6. 63 Stat. 205.

453. This may be viewed as a standing argument. It is difficult to see how someone could receive sufficient direct imjury from a reorganization plan to complain of the procedure employed. In the language of Mechem, reorganization does not involve "some portion of the sovereign functions of government." See text accompanying note 392 supra. 
organization may be regarded as a decision about how to govern rather than as a substantive exercise of power. This may be an area particularly appropriate for agreement between the President and Congress about distribution of functions.

While the author hesitates to declare that use of these four extralegislative procedures for reorganization should be beyond the reach of Congress, it is nevertheless suggested that the mechanism of disapproval by simple resolution is most in accord with the purposes of the Framers (discounting approval by concurrent resolution as being sufficiently similar to approval by legislation to constitute an unlikely substitute). However, it is further suggested that in the area of reorganization it would not put significant additional burden on Congress to require adoption of the President's plan by legislation under suitable noamendment and limited debate rules. This would prevent misunderstanding concerning the permissible scope of extra-legislative procedures such as occurred following the 1939 Reorganization Act. ${ }^{454}$

iii. Substantive presidential rulemaking. Early use of the "laying system," defined above as response by resolution to proposals laid before Congress, was restricted to reorganization. Recent statutes have extended its use to substantive rulemaking, ${ }^{455}$ involving formulation of rules which regulate behavior. This subsection considers the validity of statutes authorizing congressional response to presidential rulemaking. . $^{456}$

There are several differences of potentially constitutional significance between use of resolutions to respond to presidential substantive rulemaking and use of resolutions to respond to reorganization proposals. The use of congressional resolutions in the rulemaking context, if valid, would be much less subject to limitation than their use in the case of reorganization. The scope of substantive governnental powers to which the device clearly could be applied is vast if substantive rulenraking is a valid context for use of resolutions, and furthermore the boundaries of "rulenraking" are not well-defimed. The potential for

454. See Appendix A.

Should Congress reserve the right to amend the President's plan, or to selectively adopt portions thereof, this conclusion would no longer hold. In that case Congress would be creating a power to affect governmental organization without presidential assent and without necessity for override of his veto. This would preserve the power that enabled Congress to pass such a statute initially. Though the President could still respond by refusing to subunit a reorganization plan, any plan which he did submit would amount to a blank check and would portend domination of the Executive.

455. See, e.g., Act of Aug. 21, 1974, Pub. L. No. 93-380, \$ 509(a), 88 Stat. 484; Act of Oct. 27, 1974, Pub. L. No. 93-492, $\$ 109,88$ Stat. 1470; Act of Dec. 19, 1974, Pub. L. No. 93-526, § 104, 88 Stat. 1696.

456. E.g., The Emergency Petroleum Allocation Act of 1973, Pub. L. No. 93-159, $\S 4(\mathrm{~g})(2), 87$ Stat. 627. 
extensive use carries with it the possibility that the President would not directly participate in the submission of rules to Congress. Within the context of "reverse legislation," this would be equivalent to presidential delegation of the veto power. Also, where the laying device is used to pass upon rules inade pursuant to an ongoing governmental program, the President could be deprived of the option of not acting, a valuable presidential option in the case of reorganization. Finally, formulation and adoption of substantive regulations constitutes exercise of the sovereign power of government. This may require closer adherence to constitutional norms than does governmental reorganization.

The third and fourth procedures are considered first. Disapproval by concurrent resolution and approval by simple resolution of regulations proposed by the President allow adoption of those regulations even though only a single House approves. It was suggested in the discussion of reorganization that this does not impermissibly avoid the "constitutional averaging" required of measures einerging from Congress, provided that neither House participates in the fornulation of the President's proposal. However, a House need not be involved in the drafting of a proposal to participate in its formulation: either House could participate by informally influencing the President. Such improper influence must be more strictly avoided in dealing directly with substantive power than in reorganization, which involves non-substantive government action. Furthermore, the possibility of influence is enhanced in the rulennaking context. The likelihood of increased urgency in administering an ongoing program encumbered with prior commitments may result in increased pressure on the President to formulate rules acceptable to a single House. ${ }^{457}$ This pressure nnay be compared to the informal committee pressure on admimstrators which was earlier found to evade constitutional condemnation. Here, however, a House not only applies pressure on the President, it is given final authority to effectuate the resulting rules. This provides a clear object for constitutional attack. Finally, the broad potential use of these procedures in government poses the threat of frequent use, adding up to a large cuinulative effect on government operation not present in the case of isolated reorganization provisions.

These additional factors require that the third and fourth procedures be considered invalid mechamisms of control over presidential

457. Of course, in the case of the legislative scheme, as well as in the case of procednres one and two, the pressure to obtain adoption of some measure may be just as great as in the case of procedures three and four. In the former procedures, however, the President must persevere until he submits a measure acceptable to both Houses. In these there will also be pressure on the Houses of Congress to abstain from requiring of the President measures unacceptable to the other House. 
rulemaking. Disapproval by concurrent resolution and approval by simple resolution, marginally valid in the reorganization context, allow impermissible single-House influence in the context of substantive presidential rulemaking. ${ }^{458}$

The two remaining procedures, approval by concurrent resolution and disapproval by simple resolution, were both held valid in the reorganization context. Here, as there, both procedures allow the President and Congress the same relative powers with respect to a particular presidential proposal as would exist without specially authorized procedures. The proposal must be favored by the President and by both Houses. ${ }^{459}$ As before, the first procedure is indistinguishable in effect from legislation. The second procedure, however, requires a different conclusion in the present substantive context. As discussed earlier, the importance of disapproval by simple resolution lies in the passive nature of Congress' resulting control. ${ }^{460}$ The device allows Congress to retain control over day-to-day governmental activities, and yet relieves it of the burden of responding to every presidential action.

This nay be seen to subvert the customary interdepartinental check on power, for Congress is allowed to control the power it creates. This will allow Congress to create powers in excess of those it would normally grant to the President. Though the President must exercise these powers under the watchful eye of the legislature, Congress is not bound by standards similar to those it would otherwise be likely to impose on the President. The result is that while the President and Con-

458. This analysis is supported by the possible effect of the laying system on judicial review. Ordinarily Congress specifies standards for executive action under delegated powers. Executive adherence to these standards may be enforced by the judiciary. In enforcing these standards, the judiciary looks to the intent of Congress at the time of enactment of the original executive power. Traditionally, an expression, such as by concurrent resolution, of the opinion of today's Congress as to the intent of yesterday's is considered ineffective. See, e.g., 6 OP. ATT'Y GEr. 680 (1854); Gibson, Congressional Concurrent Resolutions: An Aid to Statutory Interpretation? 37 A.B.A.J. 421 (1951). To give effect to such an opinion in a proceeding to enforce legislative standards would give Congress a chance to change those standards without legisiating. It has been suggested that if Congress is given a role in the formulation of regulations this situation would change; that judicial review might be reduced to a review for compliance with due process standards. See Harvard Note, supra note 434, at 647. If the effect of the laying system would indeed be the suggested judicial deference, this would again give Congress the opportunity to alter the legislative standards, if any, which it had once promulgated by statute. This would seem appropriate only if the approval process is equivalent to legislation. Either House of Congress should then have the power to disapprove the change in standards.

459. Of course, if two-thirds of each Hosue favors action which the President refuses to initiate, Congress may take over by enacting the desired rules through legislation, overriding the President's veto if necessary. The President is thus not given an absolute veto through refusal to act under the laying system.

460. See note 444 and accoinpanying text supra. 
gress stand in the same relative positions with respect to the exercise of power, the two branches considered as a unit exercise a power greater than that which would be possible without passive control. This expansion of federal power is precisely what the Framers sought to avoid in placing the power to legislate and the power to execute the laws in different hands. Therefore this procedure, disapproval by simple resolution, should be held impermissible in the context of presidential substantive ruleinaking.

\section{b. The "Laying System" as Applied to Agency Activities}

Administrative lawmaking is a role more often assigned to administrative agencies than to the President; and the congressional assumption of a supervisory role over such lawmaking has expanded rapidly during the Nixon and Ford Administrations. ${ }^{461}$ This supervision may be expressed through any of the four procedures discussed in connection with presidential lawmaking, and the considerations discussed there apply equally to administrative lawmaking. Where supervisory power is retained over an independent agency not directly responsible to the President, however, the discretionary impact takes on a new aspect: congressional discretion can be exercised independently of the President. Thus the procedure loses the "reverse legislation" character of control over presidential lawmaking. This ability of Congress to act without presidential check might also be characterized as having preservative nnpact, but this additional step is unnecessary to the following analysis.

Congress' reservation of a government role for itself and exclusion of the checking influence of the Executive provide an opportunity for congressional dominance of government which does not exist when post-legislative control is restricted to presidential lawmaking. ${ }^{462}$ Furthermore, the possibility of control over independent agencies offers Congress a much more potent tool for expanding federal power than does control over presidential lawmaking. Under the four procedures for control, an agency dependent on Congress for its funding and existence $^{463}$ would be authorized to submit proposed rules or changes in

461. See Appendix A and note 455 supra.

462. The Defense Reorganization Act of 1958, Pub. L. No. 85-599, 72 Stat. 514, provides an example of a congressional attempt to reduce the President's governmental role, and simultaneously enhance its own. That Act called for submission directly to Congress of a plan for reorganization of the military formulated within the Defense Department. This plan was to take effect automatically subject to congressional veto. See note 143 supra.

463. It has been suggested that whatever objection there may be to the congressional supervision of administrative agencies, "the objection cannot apply to the independent regulatory commissions, which have been characterized as agencies of the legislative and judicial department." Harvard Note, note 434 supra, at 646-47 (citing Hum- 
government structure to Congress for approval. As a result, Congress will not only have a veto power over the proposal, but is also likely to play an active part in their formulation. The President would be unable to provide a countervailing force. The possible elimination of effective judicial review of administrative compliance with statutory standards ${ }^{464}$ could allow Congress to alter at will the standards applicable to the admimistrative action in question. Indeed, the procedure could render the original statement of standards unnecessary. ${ }^{405}$ This concentration of power in a single branch of government is precisely the situation feared by the Framers as likely to lead to an unacceptable expansion in the scope of federal power.

In addition to the constitutional failings present in three of the four procedures for control of presidential rulemaking, all four procedures violate the two institutional criteria-congressional dominance and increase of federal power-when applied to adninistrative lawnaking beyond presidential control. This application of the "laying system" must therefore be considered invalid.

\section{Non-Statutory Control of Executive Actions}

\section{a. To Order or Prevent Administrative Action}

On several occasions Congress has enacted legislation committing certain actions to administrative discretion, but permitting Congress to circumvent that discretion later by ordering executive action. Thus the Alien Registration Act of 1940 and related acts, ${ }^{406}$ define the conditions under which an alien may be subject to deportation, but authorize indefinite suspension of deportation according to the discretion of the proper administrative officer. The suspension, however, may be overruled by concurrent resolution of Congress, in which case the alien must be deported. ${ }^{407}$ A second example is provided by the Budget and Impoundment Control Act of $1974 .{ }^{488}$ This Act provides that the Presi-

phrey's Ex'r v. United States 295 U.S. 602, 628 (1935)). This is plainly wrong. That a commission acts as an agent of the legislative department makes more emphatic the necessity that these bodies not be used as tools to give Congress a lawmaking role independent of the President.

464. See note 458 supra.

465. See Harvard Note, note 434 supra, at 646.

466. See Appendix A.

467. But for the occasionally cavalier approach the Supreme Court has taken with the rights of aliens to enter or remain in the United States, see Shaughnessy v. United States ex rel. Mezei, 345 U.S. 206 (1953), one would be tempted to say that such a vote would constitute a bill of attainder-at least if it may be regarded as a legislative act. See United States v. Lovett, 328 U.S. 303 (1946). It would seem somewhat anomalous that an otherwise invalid act of Congress might be validated by the fact that it did not require approval of the President.

468. Congressional Budget and Impoundment Control Act of 1974, Pub. L. No. 93344, 88 Stat. 297. 
dent must report to Congress his intent "to defer any budget authority provided for a specific purpose or project." Either House of Congress is then empowered to express its disapproval, compelling the administration to make available for obligation the budget authority in question. ${ }^{469}$

If this use of resolutions is available to Congress, that body may enact legislation at one poimt in time, and later effectively modify that legislation without presidential approval. Assuming, for example, that the President normally has the power to impound appropriated funds, but that Congress has the power to require by explicit provision that the funds be spent, ${ }^{470}$ then a resolution passed under the Budget and Impoundment Control Act has the effect of writing such a provision into an appropriation. This "provision" to which the President currently objects, is one which was not present when he signed the appropriation bill. Furthermore, simce the Budget Act calls for a simple resolution, this change in the law may be brought about by a single House of Congress, unchecked by its opposite member. The Budget and Impoundment Control Act clearly takes the legislative power which Congress has mustered at one point in time-whether that power arises from force of numbers or presidential concurrence-and bestows that power upon each House. A later appropriation, though it might be vetoed were it to contain a mandatory spending clause, may be "amended" after enactment by vote of either House. ${ }^{471}$

The power Congress has assuned over the fate of aliens threatened with deportation affords another example of the effect of statutes giving the legislature control over administrative actions. Under such authority Congress becomes the interpreter and enforcer of its own statutes. ${ }^{472}$ It may grant broad discretion to administrators with minimal specification of standards and then control the administrator's discretion-in effect exercising that discretion itself. In so acting it may

469. Id. \$ 1013 (a), (b), 88 Stat. 334.

470. See 42 Op. ATT'y Gen. 32 (1967); Rehnquist, Memorandum, Presidential Authority to Impound Funds Appropriated for Assistance to Federally Impacted Schools (Dec. 1, 1969), reproduced in 116 CoNG. REc. 343 (1970).

471. Of course it may be objected that appropriations enacted after the budget act in effect contain a potential mandatory spending clause and that the President has the opportumity to veto individual appropriations on this basis. The answer to this is that Congress could explicitly insert such a provision into each appropriation without need for the budget act provision. Veto of appropriations on the basis of the possibly remote contingency posed by the threat of vote under the budget act would require the President to initiate and take political responsibility for a constitutional encounter with each appropriation, but would lay no corresponding onus on Congress.

472. Compare the case considered by Attorney General Cushing in which Congress, by resolution, ordered relief for an individual under previously enacted authority. The Attorney General ruled the resolution ineffective, though he did reserve judgment on the case where Congress provided in advance for such resolutions. See text accompanying note 47 supra. 
deviate from prescribed standards, and indeed nnay act without specifying the standards under which it acts. This would seen to be the case where Congress may, without explanation, order the expulsion of an alien in the face of an administrator's discretionary decision to suspend deportation. ${ }^{473}$

This category of control, therefore, may have a preservative impact allowing Congress to dominate the Executive in a manner not possible without the procedure. In addition, the impacts observed in the ease of control over formulation of rules for general application, and the resulting infringement of the institutionsl and conflict of interest criteria, become more acute where Congress takes control over specific administrative actions. In this area, Congress truly does assume discretionary control over administration of the law, replacing the executive branch in its traditional role. The potential for extensions of governmental power is nnaximized by elimination of the need for prestated standards for administrative actions: Congress may act in particular instances without stating its reasons. Judicial review of administrative action for compliance with legislative standards, if that action is validly subject to the approval or disapproval of Congress, would very likely be narrowed or eliminated. ${ }^{44}$ This concentration of power within one governmental department is wholly inconsistent with the Framers' concept of separation of powers.

\section{b. As a Check on Non-Statutory Actions}

The War Powers Resolution passed in 1973 provides:

[A]t any time that the United States Armed Forces are engaged in hostilities outside the territory of the Umited States, its possessions and territories without a declaration of war or specific statutory authorization, such forces shall be removed by the President if Congress so directs by concurrent resolution. ${ }^{475}$

Thus congressional control by resolution is here explicitly restricted to situations where the President has acted without statutory authority.

This use of resolutions draws judicial support from Youngstown Sheet and Tube v. Sawyer. ${ }^{478}$ In Youngstown, President Truman acted without statutory authority to take over a steel mill and thereby avert a strike during the Korean war. In deciding that the takeover exceeded the President's constitutional authority, the Supreme Court

473. For a discussion of the necessity of administrative standards, see Environmental Defense Fund v. Ruckelshaus, 439 F.2d 584 (D.C. Cir. 1971). It seems unlikely that a similar statement of findings could be required by Congress, or that Congress on its own could effectively make such a statement.

474. See text at note 458 supra.

475. Pub. L. No. 93-148, \& 5(c), 87 Stat. 555 (1973).

476. 343 U.S. 579 (1952). 
considered it relevant that Congress had recently considered bestowing upon the President the very power which he had exercised but had declined to do so. Apparently when the President thus acts within the "zone of twilight in which he and Congress may have concurrent authority, or in which its distribution is uncertain," ${ }^{477}$ the present mind of Congress, if ascertainable, is relevant.

To allow a contemporary Congress to express an opinion as to the intent of an earlier Congress clearly presents an opportunity for statutory revision without presidential consent. Where the present mind of Congress has operative significance, however, the story may be different. If a provision for congressional control by resolution is restricted to a situation where (1) the President has some inherent authority to act in the absence of statute, ${ }^{478}$ and (2) the area is one where Congress would possess power to control executive actions by statute, Youngstown, as well as the analysis of this Comment, leads to the conclusion that a resolution under an act such as the War Powers Resolution is a valid exercise of congressional power.

Congressional control by resolution in these circumstances provides a check on governmental power where otherwise none might exist. When Congress grants authority to the President by statute, it has the opportunity to control exercise of power under that authority by restrictions within the statute. In this case, later control by resolution only serves to replace that standard method of control. But if the President acts without support of statutory authority, Congress clearly has no opportunity for exercise of standard statutory controls.

If an inherent authority to act without statutory authority is conceded the President, then to insist that control be by statute is to guarantee that the President's power will be virually unlimited. Congress will not be able to stop a President determined to exercise inherent powers if his action is favored by one-third of either House. It is also likely that judicial review will be hindered in many cases by pohtical question considerations. Only by allowing Congress to exercise control by resolution in this situation can the quality of governmental checks be maintained.

While one inight conclude from Youngstown that a preparatory act such as the War Powers Resolution would be unnecessary-that a concurrent resolution unsupported by statute would be sufficient to convince a court that the President acted beyond his authority-there would be no compulsion in such a resolution. Enactment of a statute authorizing disapproval of non-statutory executive action provides com-

477. Id. at 637 (Jackson, J., concurring).

478. If the President had no inherent authority and there were no statute, the President's action clearly would be invalid. 
pulsion without need for judicial process. If the President violates the mandate of a resolution so authorized, he acts not merely without support of law, but in violation of law-presumably an offence which could subject him even to impeachment.

Nor is this consideration overbalanced by considerations which beset other uses of resolutions for control of the executive. The restriction to non-statutory acts presents a clear and principled line to himit spread of the device. By analogy to the Court's treatment of Youngstown, it seems appropriate to treat the authorized congressional resolution not as a legislative act but as a refusal to legislate. The President, of course, has no power to veto Congress' refusal to enact legislation. ${ }^{470}$ The authorizing statute in this situation does not preserve legislative power; it puts the force of law behind a power which Youngstown recognizes in Congress in any event-the power to refuse to grant the powers sought.

Finally, in this context use of resolutions would not seem to give Congress significant discretionary power. It may respond only to those executive actions taken without statutory authority in areas where the President claims inherent power. It may only respond by directing the Executive to cease the action in question. ${ }^{480}$ There seems no potential in this procedure for congressional dominance of the Executive in his normal functions, and there is no question of expansion of governmental power.

\section{Congressional Actions Independent of the Executive}

There remains to be discussed a miscellany of actions by resolution which neither directly respond to nor order admimistrative actions. These include the termination of statutory authority-a common provision during the Roosevelt and Truman administrations ${ }^{481}$ - the removal of officers, ${ }^{482}$ or effectuation of a program. ${ }^{483}$

Provisions which call for termination or initiation of statutory authority by resolution are perhaps the baldest examples of legislation

479. By this analysis control by simple resolution should be allowable, though perhaps in order to assure reasoned action through the bicameral check, concurrent resolution should be required.

480. Presumably it would be permissible to specify an orderly procedure for cessation of the banned activity. Of course, given congressional power to forbid his action entirely, the Executive might submit to statutory controls of his actions instead.

481. See Appendix A.

482. This was attempted, for example, on the occasion of one of President Wilson's vetoes; see text following note 84 supra, and was provided for in the creation of the TVA, Tennessee Valley Authority Act of 1933, ch. 32, 48 Stat. 60. See note 119 supra.

483. E.g., The Federal Aid Highway Act of 1944, ch. 626, 58 Stat. 838, 839. 
by resolution..$^{484}$ The primary support offered for this use of resolutions, aside from expediency, is the "mere contingency" notion which sprang from Currin v. Wallace, ${ }^{485}$ and which has previously been discussed. ${ }^{480}$ The only excuse for such measures is the fear that when Congress desires to act as specified, the President may disagree. If this is suficient reason to eliminate the President's voice from future legislation in a given area, then it is difficult to see a limitation on the device. The authorizing statute preserves legislative power in a manner which has the potential for eliminating the Executive's check on legislation and fostermg legislative dominance. More conventional checks on statutory power may be awkward in some cases, but there seems no reason to believe that such checks are madequate.

Other provisions for congressional action independent of executive action, and without opportunity for veto, similarly threaten legislative dominance. For example, congressional power to remove by resolution administrators who follow the President rather than the desires of Congress might be as effective in giving Congress dominant power over administrative actions as would be direct control. In general, this category of statutes must be adjudged unconstitutional.

\section{CONCLUSION}

The control of administrative action by Congress, its individual members, or its committees, where this control is expressed by actions outside the constitutionally specified legislative process, creates a role for legislators which was neither specifically discussed by the Framers nor clearly banned by the Constitution. This role did not find expression until the 20th century and had no important effect on government until World War II. Following World War II, use of extra-legislative control procedures declined, but it has increased again in recent months. These procedures are potentially incompatible with the intentions of the Framers. Where such conflict is found to exist, the procedures are within the logical reach of the language of the Constitution and should be considered invalid.

484. Ginnane discusses the Framers' intent that repeal of a statute, like its enactment, be considered a legislative event. Ginnane, supra note 13, at 587-88.

485. 306 U.S. 1 (1939).

486. See text at note 140 supra. There is one situation where the contingency theory takes on some credence. To state that the resolution represents a finding of fact, and that it is the existence of this fact which triggers legal consequences, is of little significance if only one statutory consequence flows from this finding. If, on the other hand, a complex system of statutory authority simultaneously rises or falls with the finding, so that Congress cannot be selective - shaping its findings to fit a desired consequence-then the contingency theory approaches believability. However, the question remains: even if what is involved is really a finding of fact, why shouldn't the President have the power to disagree? 
The devices for control considered in this Comment involve the assumption by Congress of procedural powers, as distinct from substantive powers, not explicitly granted to it by the Constitution. Unlike the exercise of substantive powers, which can be judged on a case-bycase basis, ${ }^{487}$ the validation of a procedure is cumulative in effect and difficult to limit through disallowance in particular cases. However, if use of a specific procedure in one of the distinct areas of application examined in this Comment is found not to violate constitutional principle, it should be possible to conclude that such use is valid, and yet prohibit its spread beyond the established bounds.

Regarding specific procedures, no satisfactory subcategory of use for the committee veto lias been found within which that procedure could be employed without infringement of the constitutional criteria derived in Section III. The committee veto, therefore, and a fortiori formal exercise of power by individual legislators, should be considered per se invalid. Only two categories of control by resolution lave been found in which the procedures may be valid. The first, congressional response by resolution to presidential reorganization proposals, appears to be both confinable and constitutionally innocuous. However, there seems to be hittle reason for use of resolutions instead of standard legislative procedures with appropriate congressional rules. The second, use of resolutions for control of nonstatutory actions by the administration, on the other hand, may be potentially useful, confinable, and not in conflict with the constitutional criteria. The validity of this type of control, as employed in the War Powers Resolution, lowever, requires that the statute authorizing congressional action not be imterpreted to authorize administrative action subject to congressional veto. Such statutory interpretation would remove the control device froin the immediate category of use and thereby render it invalid. Use of simple and concurrent resolutions in all other categories examined in this Comment should be considered invalid as inconsistent with the Framers' intentions and their views of the separation of powers.

487. The broad scope of Congress' substantive powers under the necessary and proper clause, in the absence of specific restrictions, was established long ago in McCulloch v. Maryland, 17 U.S. (4 Wheat.) 311 (1819). 
APPENDIX A

The following is a partial compilation of statutes authorizing congressional action by simple or concurrent resolution which have been enacted since 1932. Unless simple resolution is indicated, the authorized action is by concurrent resolution. Where the parenthetical explanation simply states "termination," the act authorizes either termination of the act itself or of all powers authorized by the act, by resolution. During the World War II period, a large number of statutes were enacted which were to terminate automatically at a specified time after passage of a previously authorized concurrent resolution announcing the end of the war. These acts, which do not themselves authorize subsequent resolutions, are not included here. tion);

Act of June 30, 1932, ch. 314, § 407, 47 Stat. 414 (reorganization-simple resolu-

Tennessee Valley Authority Act of 1933, ch. 32, § 4, 48 Stat. 60 (removal of board nembers);

Reorganization Act of 1939, ch. 36, § 5, 53 Stat. 562-63;

Neutrality Act of 1939, ch. 2, § 1, 54 Stat. 4 (presidential proclamation compelled on congressional finding of state of war);

Alien Registration Act of 1940, ch. 439, $\$ 20,54$ Stat. 672 (authorization of suspension of deportation subject to congressional disapproval in particular cases);

Lend Lease Act of 1941, ch. 11, \&3(c), 55 Stat. 32 (termination of the President's authorized powers upon finding that such powers are no longer necessary);

Selective Service Extension Act of 1941, ch. 362, $\$ 2$, 55 Stat. 626 (revocation of power delegated to the President to extend period of service);

First War Powers Act, ch. 593, \& 401, 55 Stat. 841 (1941) (termination of powers);

Act of Jan. 20, 1942, ch. 7, § 2, 56 Stat. 9 (repeal daylight savings time);

Einergency Price Control Act of 1942, ch. 26, § 1(b), 56 Stat. 24 (specify date of termination);

Act of Mar. 6, 1942, ch. 154, 56 Stat. 140 (termination);

Second War Powers Act, ch. 199, \& 1501, 56 Stat. 187 (1942) (termination of powers);

Act of April 29, 1942, ch. 266, § 3, 56 Stat. 265 (termination);

Act of June 5, 1942, ch. 340, § 16, 56 Stat. 317 (termination);

Act of June 11, 1942, ch. 404, $\$ 12,56$ Stat. 357 (termination of section);

Act of June 16, 1942, ch. 416, 56 Stat. 370 (termination);

Act of June 30, 1942, ch. 461, 56 Stat. 463 (termination);

Act of July 2, 1942, ch. 471, \& 3, 56 Stat. 468 (termination);

Act of July 30, 1942, ch. 538, 56 Stat. 731 (termination);

Act of Aug. 1, 1942, ch. 544, 56 Stat. 736 (termination of permission for use of Canadian flag ore ships between U.S. ports on Great Lakes);

Act of Oct. 1, 1942, ch. 570, 56 Stat. 762 (termination);

Act of Oct. 2, 1942, ch. 578, $\$ 6,56$ Stat, 767 (termination of portion of act and regulations thereunder);

Act of Oct. 10, 1942, ch. 588, 56 Stat. 781 (termination);

Act of Oct. 10, 1942, ch. 589, 56 Stat. 781 (end suspension of statute of limitations on antitrust laws);

Act of Oct. 16, 1942, ch. 613, 56 Stat. 795 (end suspension of prior act);

Act of Oct. 29, 1942, ch. 632, 56 Stat. 1012 (termination of authority to grant scholarships, and termination of existing scholarships);

Act of Nov. 23, 1942, ch. 639, 56 Stat. 1021 (termination);

Act of Dec. 8, 1942, ch. 697, § 3, 56 Stat. 1044 (disapproval of suspension of deportation);

Act of Dec. 17, 1942, ch. 739, § 4, 56 Stat. 1054 (termination);

Act of Dec. 22, 1942, ch. 801, \& 4, 56 Stat. 1071 (termination);

Act of Dec. 29, 1942, ch. 836, 56 Stat. 1096 (termination on limitations on construction of Communications Act of 1934); 
Act of Apr. 1, 1943, ch. 32, § 2, 57 Stat. 57 (termination); Act of Apr. 9, 1943, ch. 37, § 3, 57 Stat. 59 (termination); Act of Apr. 9, 1943, ch. 40, $\$ 2,57$ Stat. 61 (termination); Act of May 7, 1943, ch. 93, § 14, 57 Stat. 78 (termination); Act of May 29, 1943, ch. 107, § 1, 57 Stat. 92 (termination); Act of June 1, 1943, ch. 109, 57 Stat. 93 (termination);

Act of June 15, 1943, ch. 126, § 10, 57 Stat. 155 (termination);

Act of June 17, 1943, ch. 130, 57 Stat. 158 (termination);

Federal Aid Highway Act of 1944, ch. 626, $\$ 2,58$ Stat. 839 (initiation of threeyear program);

Act of Mar. 21, 1945, ch. 29, § 5, 59 Stat. 37 (termination);

Act of Mar. 21, 1945, ch. 30, \$ 5, 59 Stat. 37 (termination);

Act of June 30, 1945, ch. 207, 59 Stat. 271 (termination);

Reorganization Act of 1945, ch. 582, $\S 6(\mathrm{a}), 59$ Stat. 616 (disapproval of plan);

Act of Dec. 28, 1945, ch. 590, $(\mathrm{f}), 59$ Stat. 658 (termination);

Federal Airport Act of 1946, ch. 251, § 8, 60 Stat. 174 (disapproval of particular airport projects);

Act of May 22, 1947, ch. 81, \& 6, 61 Stat. 105 (termination of aid to particular countries);

Foreign Assistance Act of 1948, ch. 169, 122 (a), 62 Stat. 155 (ternination);

Displaced Persons Act of 1948, ch. 647, § 4(a), 62 Stat. 1011, as amended, 64 Stat. 224 (1950) (grant status of permanent resident);

Act of July 1, 1948, ch. 783, 62 Stat. 1206 (Congress must within six months affirmatively approve suspension of deportation);

Reorganization Act of 1949 , ch. 226, $\$ 6,63$ Stat. 205 (disapproval by simple resolution);

Mutual Defense Assistance Act of 1949, ch. 626, $\$ 405$ (d), $\S 408$ (f), 63 Stat. 718, 720 (order termination of aid, order retention of materials procured for foreign country);

Act of Aug. 9, 1950, ch. 656, $\$ 4,64$ Stat. 428 (Act controlling foreign flag vessels - specify date of expiration);

Defense Production Act of 1950, ch. 932, § 716(c), 64 Stat. 822 (terminate any portion of Act);

Federal Civil Defense Act of 1950, ch. 1228, \& 201(g), 64 Stat. 1249 (1951) (consent of Congress to interstate compact deemed given unless disapproved within 60 days); id. at $\$ 301,64$ Stat. 1251 (actuate emergency authority); id. at § 307, 64 Stat. 1254 (termination of emergency authority);

Universal Military Training and Service Act of 1951, ch. 144, \& 1(j), 65 Stat. 80 (reduction or elimination of the satutory service obligation of any age group);

Immigration and Nationality Act of 1952, ch. 447, \& 244(b), 66 Stat. 216 (authorize simple resolution disapproval of certain deportation suspensions); id. at $\$ 244$ (c), 66 Stat. 216 (require concurrent resolution approval of other deportation suspensions);

Rubber Production Facilities Disposal Act of 1953, cl. 338, \& 9(b), 67 Stat. 412 (simple resolution rejection of part or all of proposed government contracts);

Federal Highway Act of 1956, ch. 462, § 108(d), 70 Stat. 379 (approval of highway fund allocation proposals);

Act of Sept. 11, 1957, Pub. L. No. 85-316, \& 13(c), 71 Stat. 642-43 (simple resolution to set aside deportation decision and order deportation);

Act of July 2, 1958, Pub. L. No. 85-479, § 4, 72 Stat. 277 (set aside agreement to exchange military information and atomic materials);

Department of Defense Reorganization Act of 1958, Pub. L. No. 85-599, § 3, 72 Stat. 514-15 (simple resolution disapproval of military reorganization plan submitted oy the Secretary of Defense);

Trade Agreements Extension Act of 1958, Pub. L. No. 85-686, \& 6, 72 Stat. 676 (If President rejects a decision of the Tariff Cominission, Congress can override by such rejection two-thirds vote of each House); 
Arms Control and Disarmament Act, Pub. L. No. 87-297, $\S 47($ b), 75 Stat. 638 (1961) (simple resolution disapproval of presidential transfer of activities relating to arms control);

Trade Expansion Act of 1962, Pub. L. No. 87-794, § 351, 76 Stat. 899 (If President rejects a decision of the Tariff Commission, Congress can override such rejection by a vote of the majority of the membership of each House);

Act of Sept. 6, 1966, Pub. L. No. 89-554, § 906, 80 Stat. 378 (reorganizationdisapproval by simple resolution-codification of Title 5, United States Code);

Veterans Pension and Readjustment Assistance Act of 1967, Pub. I. No. 90-77, § 201 (a), (b), 81 Stat. 181-82 (definitions of "period of war," and "Vietnam era" for purposes of veterans' benefits-provisions for termination by concurrent resolution);

Export Administration Act of 1969, Pub. L. No. 91-184, § 14, 83 Stat. 847 (termination);

Act of Apr. 13, 1970, Pub. L. No. 91-230, $\$ 401$ (a) (6), 84 Stat. 165 (Education Amendments-termination of authorization extension by simple resolution);

Federal Pay Comparability Act of 1970, Pub. L. No. 91-656, § 3(a), 84 Stat. 1948 (disapproval by simple resolution of President's emergency alternative pay increase plan for federal employees-see S. Res. 394, 93d Cong., 2d Sess., 120 CoNG. REc. S17126 (daily ed. Sept. 19, 1974));

Act of Oct. 27, 1972, Pub. L. No. 92-578, § 5(d), 86 Stat. 1269-70 (simple resolutions disapproval of corporation's redevelopment plans when the Secretaries of Interior and Commerce disagree);

War Powers Resolution, Pub. L. No. 93-148, § 5(c), 87 Stat. 556-57 (1973) (disapprove non-statutory hostile actions, order removal of troops);

Act of Nov. 16, 1973, Pub. L. No. 93-155, \$\$ 807(a), (b)(1), (c), (d) (1), 87 Stat. 615-16 ((a) simple resolution disapproval of proposed government obligation, (b)(1) simple resolution disapproval of proposed loan, (c) simple resolution disapproval of proposed payment, (d) (1) simple resolution disapproval of proposed order to pay);

Emergency Petroleum Allocatiou Act of 1973, Pub. L. No. 93-159, § 4(g)(2), 87 Stat. 633 (disapproval of President's proposed amendment to regulations);

Menominee Restoration Act, Pub. L. No. 93-197, \&6(b), 87 Stat. 773 (simple resolution disapproval of plan submitted by the Secretary of the Interior to assume the assets of Menominee Enterprises, Inc.);

District of Columbia Self Government and Governmental Reorganization Act, Pub. L. No. 93-198, § 602(c)(1), 87 Stat. 814 (disapproval of acts of the District of Columbia Council);

Congressional Bndget and Impoundment Control Act of 1974, Pub. I. No. 93-344, $\S 1013(\mathrm{~b}), 88$ Stat. 335 (disapproval by simple resolution of presidential impoundment of funds);

Act of Aug. 17, 1974, Pub. L. No. 93-377, \& 2, 88 Stat. 474 (disapprove proposed distribution of nuclear material to foreign nation);

Forest and Rangeland Renewable Resources Planning Act of 1974, Pub. L. No. 93-378, \& 7(a), 88 Stat. 478 (simple resolution disapproval of authorized presidential statement of policy);

Education Amendments of 1974, Pub. L. No. 93-380, \$ 509(a), 88 Stat. 567 (determination that standard, rule, regulation, or requirement promulgated by commissioner is inconsistent with act);

Act of Oct. 26, 1974, Pub. L. No. 93-485, 88 Stat. 1460 (disapproval of proposed agreement for nuclear cooperation);

Motor Vehicle and Schoolbus Safety Amendments of 1974, Pub. L. No. 93-492, \$ 109,88 Stat. 1483 (disapproval of motor vehicle safety standard promulgated by administrator);

Act of Dec. 19, 1974, Pub. L. No. 93-526, $\$ 104,88$ Stat. 1697 (simple resolution disapproval of regulations relating to access to presidential tapes);

Act of Dec. 27, 1974, Pub. L. No. 93-552, § 613, 88 Stat. 1766 (simple resolution disapproval of military building project); 
Act of Jan. 2, 1975, Pub. L. No. 93-595, § 2, 88 Stat. 1926 (simple resolution disapproval of Supreme Court amendments to statutory rules of evidence);

Trade Act of 1974, Pub. L. No. 93-618, §§ 151-53, 88 Stat. 2001-08 (1975) (approval of agreement or disapproval of presidential act or determination);

Export Import Bank Amendments of 1974, Pub. L. No. 93-646, § 8, 88 Stat. 2336 (approval of proposed presidential action). 


\section{APPENDIX B}

The following is a partial listing of statutes which have authorized subsequent action by one or more committees of Congress:

Act of Apr. 4, 1944, ch. 165, 58 Stat. 190 ("come into agreement" prior to disposing of naval land);

Naval Appropriation Act of June 17, 1944, ch. 262, 58 Stat. 281 (consultation over contract terms regarding utilization of naval oil reserve lands-see 90 CoNG. REC. 6154 (1944) for Roosevelt objection);

Act of Apr. 19, 1945, ch. 78, 59 Stat. 53 (Foreign Service Building Commission, with a majority of members from Congress, to approve dispositions of land in foreign countries);

Act of May 11, 1949, ch. 98, 63 Stat. 66 ("come into agreement" over acquisition of land for missile site);

Act of July 5, 1949, ch. 296, 63 Stat. 405 (approval of printing to be done outside Government Printing Office);

Act of Sept. 28, 1951, ch. 434, $\$ 601,65$ Stat. 365 ("come into agreement" regarding military real estate transactions);

Act of July 14, 1952, ch. 726, $\$ 407,66$ Stat. 625 ("come into agreement" over cost of classified military construction);

Act of July 15, 1952, ch. 758, $\$ 1413,66$ Stat. 661 (committee chairman to approve changes in regulations for military housing);

Act of July 14,1955 , ch. 358, $\S 638,69$ Stat. 321 (disapproval of transfer of work from military to civilian contract);

Sinall Reclamation Projects Act of 1956, ch. 972, § 4(c), 70 Stat. 1045 (disapproval of project);

Public buildings Act of 1959, Pub. L. No. 86-249, § 11(b), 73 Stat. $481-82$ (direct building and project survey);

Act of Aug. 9, 1962, Pub. I. No. 87-578, 76 Stat. 337-38 (approval of uses of certain Indian funds);

Act of Sept. 5, 1962, Pub. L. No. 87-639, 76 Stat. 438 (direct flood control studies);

Act of Oct. 3, 1962, Pub. L. No. 87-741, 76 Stat. 727, 728 (public buildings-approval of construction expenditures, prospectus);

Act of Oct. 11, 1962, Pub. L. No. 87-796, §§ (7), (12), 76 Stat. 905, 906 (consult over disposition of naval oil shale);

Act of Oct. 23, 1962, Pub. L. No. 87-872, 76 Stat. 1164 (disapproval of reobligation of "Economic Assistance" funds);

Act of Dec. 19, 1963, Pub. L. No. 88-215, 77 Stat. 436, 437 (public buildingsapproval of construction expenditures, prospectus);

Act of Aug. 30, 1964, Pub. L. No. 88-507, 78 Stat. 654-55 (public buildings-approval of construction expenditure, prospectus);

Act of Oct. 8, 1964, Pub. L. No. 88-638, § (8), 78 Stat. 1036 (amendinent to Agricultural Trade Development and Assistance Act-prevent loans not approved by advisory committee);

Act of Aug. 16, 1965, Pub. L. No. 89-128, 79 Stat. 530-31 (public buildings-approval of construction expenditure, prospectus);

Act of Sept. 6, 1966, Pub. L. No. 89-555, 80 Stat. 674 (public buildings-approval of construction expenditure, prospectus);

Act of Nov. 3, 1967, Pub. L. No. 90-121, 81 Stat. 348-49 (public buildings-approval of construction expenditure, prospectus);

Act of June 19, 1968, Pub. L. No. 90-350, 82 Stat. 194 (public buildings-approval of locations of postal public buildings);

Act of Oct. 4, 1968, Pub. I. No. 90-550, 82 Stat. 943-44 (public buildings-approval of construction expenditures, prospectus);

Act of Sept. 29, 1969, Pub. L. No. 91-74, 83 Stat. 120 (approve locations of postal public buildings); 
Regional Action Planning Commission Amendments of 1969, Pub. L. No. 91-123, $\S 202,83$ Stat. 216 (direct administrative study regarding alteration of geographic regions);

Act of Nov. 26, 1969, Pub. L. No. 91-126, 83 Stat. 228, 229 (public buildingsapprove construction expenditures, prospectus);

Act of Apr. 13, 1970, Pub. L. No. 91-230, § 401 (a), 84 Stat. 172 (disapprove abolition of advisory council);

Act of Sept. 26, 1970, Pub. L. No. 91-422, 84 Stat. 876 (approve locations for postal public buildings);

Act of Dec. 17, 1970, Pub. L. No. 91-556, 84 Stat. 1448, 1449 (public buildingsapproval of expenditure, approval of prospectus);

Act of July 9, 1971, Pub. L. No. 92-49, 85 Stat. 119, 121 (public buildings-approval of expenditures, approval of prospectus);

Act of May 27, 1972, Pub. L. No. 92-306, 86 Stat. 175 (public buildings-approval of prospectus);

Public Buildings Amendments of 1972, Pub. L. No. 92-313, 5 5(f), 86 Stat. 220 (approval of prospectus);

Act of July 13, 1972, Pub. L. No. 92-351, 86 Stat. 484 (public buildings-approval of construction funds);

Dwight D. Eisenhower Bicentennial Civic Center Act, Pub. L. No. 92-520, § 3, 86 Stat. 1021 (approval of plans and contract);

Act of Oct. 4, 1973, Pub. L. No. 93-120, 87 Stat. 443 (consent to alteration of forest boundary or closing of regional office for research);

Act of Oct. 30, 1973, Pub. L. No. 93-143, 87 Stat. 522 (approval of public building contract);

Act of Jan. 3, 1974, Pub. L. No. 93-245, 87 Stat. 1075 (consent to alteration of forest boundary or closing of regional office for research);

Act of Mar. 7, 1974, Pub. L. No. 93-251, § 65, 88 Stat. 30 (rivers and harborsapproval of project modification);

Education Amendments of 1974, Pub. L. No. 93-380, § 509(a), 88 Stat. 566-68 (three committee approval provisions-delay or accelerate date of effectiveness of administrative regulations);

Act of Aug. 31, 1974, Pub. L. No. 93-404, 88 Stat. 817-18 (consent to alteration of forest boundary or closing of regional office for research);

Trade Act of 1974, Pub. L. No. 93-618, § 102 (c), 88 Stat. 1978, 1983 (President to consult committee prior to trade agreement). 